Marco Aurélio Soares de Castro

\title{
PREVENÇÃO DA POLUIÇÃO APLICADA ÀS EMBALAGENS DE USO INDUSTRIAL: ESTUDO DE CASO
}

Dissertação apresentada à Escola de Engenharia de São Carlos da Universidade de São Paulo, como parte dos requisitos para obtenção do Título de Mestre em Hidráulica e Saneamento.

Orientador: Prof. Assoc. Valdir Schalch 
Para meus pais Celso (in memoriam) e Jaci 


\section{AGRADECIMENTOS}

\section{A Deus}

À minha família: meus pais, irmã, avós e tios, pelo apoio, compreensão e paciência

A Eliane, pelo presente e pelo futuro

Aos colegas da graduação e pós-graduação

Ao prof. Valdir, pelos conhecimentos transmitidos, pela amizade e simplicidade Aos professores Cyro, Marcus e Edson, pelas valiosas contribuições

Ao $\mathrm{CNPq}$, pela bolsa que permitiu dedicação à pesquisa

Aos Funcionários do Departamento de Hidráulica e Saneamento, em especial a Rose, Sá e Pavi

À Volkswagen Fábrica de Motores de São Carlos, pelo apoio dado à realização da pesquisa, em especial a Márcio Lima, Washington, Ailton, Celso, Cristina, Érica, Eduardo, Aragão, Marcos e Evandro

Aos amigos, próximos ou não

Aos "irmãos de som"

À música 
"Sempre que faço uma mudança, me preocupo um pouco que ela possa confundir as pessoas. Por vezes, retenho deliberadamente as coisas por esse motivo. Mas depois descubro que nada mais há que eu possa fazer a não ser ir em frente." (John Coltrane, músico, 1926-1967)

“A inovação é a ferramenta específica dos empreendedores, o meio pelo qual eles exploram a mudança como uma oportunidade para um negócio ou serviço diferente. (...). Empreendedores precisam buscar objetivamente pelas fontes de inovação, as mudanças e os sintomas que indicam oportunidades de inovação bem-sucedida. E eles precisam saber e aplicar os princípios da inovação bem-sucedida." Peter F. Drucker (educador e escritor, 1909-2005) 


\section{$\underline{\text { Resumo }}$}

CASTRO, M. A. S. (2005). Prevenção da poluição aplicada às embalagens de uso industrial: estudo de caso. Dissertação (Mestrado) - Escola de Engenharia de São Carlos, Universidade de São Paulo, São Carlos, 2005.

O conceito de prevenção da poluição, recente em termos históricos, já tem sido abordado em estudos sobre efluentes e outros tipos de resíduos gerados diretamente a partir dos processos produtivos. Deve, porém, ser também aplicado aos resíduos gerados de forma indireta, como é o caso das embalagens utilizadas em indústrias. Isto porque, com o aumento na complexidade de tais processos, as embalagens passaram a ser empregadas também para abrigar componentes durante a fabricação e o transporte, e não mais apenas para conter o produto final; assim, sua utilização pode acarretar a geração de grandes quantidades de resíduos, se o princípio da prevenção não for adotado. Diante dessa situação, torna-se necessário suprir o setor industrial de informações acerca do conceito de prevenção da poluição, de sua aplicabilidade e contribuição para o aumento da eficiência de uma empresa. Esta pesquisa, inicialmente, apresenta considerações relativas às embalagens e à evolução dos conceitos do gerenciamento de resíduos, destacando a presença da prevenção da poluição em normas e dispositivos legais atualmente vigentes. Através de estudo de caso realizado em uma empresa montadora de motores localizada em São Carlos (SP), identifica procedimentos adequados à prevenção da poluição por embalagens de uso industrial, e analisa as embalagens cujos componentes estão envolvidos na fabricação de um determinado modelo de motor produzido na empresa. Com os dados obtidos, propõe e calcula índices de desempenho relativos, em termos quantitativos e qualitativos, aos eventuais descartes de material.

Palavras-chave: embalagem, gerenciamento de resíduos sólidos, prevenção da poluição 


\begin{abstract}
$\underline{\text { Abstract }}$
CASTRO, M. A. S. (2005). Pollution prevention applied to industrial packaging: case study. Msc. Dissertation - Escola de Engenharia de São Carlos, Universidade de São Paulo, São Carlos, 2005.

The concept of pollution prevention, historically recent, has been discussed on studies focusing effluents and other types of waste directly originated in the production processes. However, it must also be applied to the packaging waste generated in the industries. The reason is the increasing complexity of such processes, which ended up leading to a greater need for packages, which are nowadays used not only for finished products, but also during fabrication and transportation phases. Thus, the use of packages may also result in the generation of waste, if the prevention principle is not adopted. Given that situation, the industrial sector must be informed about the pollution prevention concept, its applicability and contribution to the global performance of a company. This research presents some packaging-related definitions and traces the evolution of solid waste management concepts, highlightning the presence of pollution prevention concepts in standards and legislations. Through a case study conducted in a engine-making company located in São Carlos, São Paulo State, Brazil, it identifies procedures guided by the packaging waste prevention principle, and analyzes the packages containing components involved in the fabrication of one type of engine produced in the company; with the collected data, it proposes and calculates performance indicators related to the qualitative and quantitative aspects of the material occasionally discarded.
\end{abstract}

Keywords: packaging, solid waste management, pollution prevention. 


\section{LISTA DE FIGURAS}

FIGURA 1 - Estrutura do papelão ondulado - ABPO (2004) 15

FIGURA 2 - Paletes: soluções construtivas - MOURA \& BANZATO (1997) 20

FIGURA 3 - Exemplo de montagem e tipos de divisores - MOURA (1983) 21

FIGURA 4 - Fluxos da embalagem e dos materiais e processos - JACKSON (1993), adapt. 26

FIGURA 5 - Hierarquia do gerenciamento de resíduos - JACKSON (1993), adapt. 29

FIGURA 6 - Hierarquia de opções “preventivas” - JACKSON (1993), adapt. 34

FIGURA 7 - O Ponto Verde - Câmara de Com. e Ind. Brasil-Alemanha (2004) 58

FIGURA 8 - O Anjo Azul - Câmara de Com. e Ind. Brasil-Alemanha (2004) 59

FIGURA 9 - Faturamento e divisão do setor de embalagens - ABRE (2005a) 61

FIGURA 10 - Participação de materiais no mercado - ABRE (2005a) 61

FIGURA 11 - Caixas KLT em 5 tamanhos diferentes, sobre palete plástico $\begin{array}{ll}\text { Unipac (2002) } & 80\end{array}$

FIGURA 12 - Caixamóbil - Unipac (2001) 80

FIGURA 13 - Palete vacuum-forming - Unipac (2000) 81

FIGURA 14 - Fluxo de embalagens na planta da VW 86

FIGURA 15 - Diagrama de fluxo (linha EA-111) 95 


\section{LISTA DE FOTOS}

FOTO 1 - Caixa KLT2001, de uso exclusivo entre a empresa (Fibam) e a Volkswagen

FOTO 2 - Exemplo de etiqueta aplicada às embalagens

FOTO 3 - Caixas KLT 2001, contendo parafusos protegidos por saco plástico

FOTO 4 - Rack metálico, recipientes vacuum-forming e componentes em sacos de VCI

FOTO 5 - Blocos de motor sobre berço plástico com manta de plástico bolha

FOTO 6 - Conjunto (berços plásticos e tampa vacuum-forming) fixado por cinta plástica

FOTO 7 - Caixamóbil com separadores de polionda ("grade": cinza; "placa": azul)

FOTO 8 - Caixamóbil envolta por filme plástico (ao centro)

FOTO 9 - Racks metálicos vazios no pátio externo da planta

FOTO 10 - Racks vazios no pátio interno da planta

FOTO 11 - Carrinho para coleta de descartáveis na linha

FOTO 12 - Pátio externo para coleta de resíduos 


\section{LISTA DE QUADROS}

$\begin{array}{ll}\text { QUADRO } 1 \text { - As funções da embalagem } & 12\end{array}$

QUADRO 2 - Classificação de embalagens 16

QUADRO 3 - Embalagem de consumo final x embalagem de uso industrial 26

QUADRO 4 - Identificação de aspectos e impactos - ABNT (1996b) 46

QUADRO 5 - Principais dados a serem coletados para o Inventário 71

QUADRO 6 - Métodos de gerenciamento de resíduos - exemplos de classificação 72

QUADRO 7 - Índice Global de Resíduos (IGR) - plásticos 94

QUADRO 8 - Índice Global de Resíduos (IGR) - papel e papelão 94

QUADRO 9 - Componentes e embalagens (linha Rumpf) 97

QUADRO 10 - Componentes e embalagens (linha ZP4) 99

QUADRO 11 - Índices de Resíduos de Embalagens: ECD e ESD 102

QUADRO 12 - Índices de Resíduos de Embalagens: ID1 e ID2 104 


\section{LISTA DE TABELAS}

TABELA 1 - Embalagens e geração de descarte de acessórios 102

TABELA 2 - Materiais e ocorrências de descarte 103

TABELA 3 - Materiais - participação nas ocorrências de descarte 103 


\section{LISTA DE GRÁFICOS}

GRÁFICO 1 - Embalagens - participação na geração de resíduos 


\section{SUMÁRIO}

RESUMO

$\mathbf{V}$

ABSTRACT vi

LISTA DE FIGURAS vii

LISTA DE FOTOS viii

LISTA DE QUADROS ix

LISTA DE TABELAS $\quad x$

LISTA DE GRÁFICOS xi

1. INTRODUÇÃO 3

2. OBJETIVOS 6

3. REVISÃO BIBLIOGRÁFICA

$\begin{array}{ll}\text { 3.1. Embalagem } & 7\end{array}$

3.1.1. Definições

3.1.2. Funções da embalagem 8

3.1.3. Classificação das embalagens 11

3.1.4. Materiais para embalagens 14

3.1.5. Paletes, caçambas e contêineres 18

3.1.6. Acessórios para embalagens 20

3.2. Embalagem de consumo final e embalagem de uso industrial 22

3.2.1. Finalidades 22

3.2.2. Fluxos das embalagens 23

3.2.3. A embalagem de uso industrial e o processo produtivo 25

3.3. Embalagem e meio ambiente 27

3.4. Gerenciamento de resíduos $\quad 28$

3.4.1. Reciclagem, reutilização, recuperação 30

3.5. Prevenção da poluição (P2): o conceito de redução na fonte 32

3.5.1. Benefícios da prevenção da poluição 35

3.5.2. Barreiras à prevenção da poluição 36

3.5.3. Programa de prevenção da poluição 37

3.5.4. Auditoria ambiental - identificação de oportunidades de P2 37

3.6. Produção mais limpa 39 
3.6.1. Prevenção da poluição e produção mais limpa 40

3.7. A prevenção da poluição e a série de normas ISO $14000 \quad 40$

3.8. Análise de Ciclo de Vida (ACV) 48

3.8.1. Histórico da Análise de Ciclo de Vida 50

3.8.2. A ACV nas normas ISO e legislações 51

3.9. Tendências atuais no setor de embalagem

3.10. Experiências de gerenciamento: o caso da Comunidade Econômica Européia

3.10.1. A diretiva 94/62 55

3.10.2. Selos de qualidade ambiental na Europa 58

3.11. Brasil: situação atual $\quad 60$

3.11.1. Estatísticas 60

3.11.2. Legislação federal 61

3.11.3. Resoluções CONAMA 67

3.11.4. A Política Nacional de Resíduos Sólidos 71

3.12. Conclusões - sinais do descompasso entre o Brasil e o exterior 73

4. METODOLOGIA

5. RESULTADOS E DISCUSSÕES

5.1. As embalagens

5.2. Os acessórios $\quad 82$

5.3. Fluxo de embalagens na planta 88

5.4. A geração de resíduos - os Índices Globais de Resíduos (IGR's) 93

5.5. Análise dos resíduos relativos ao produto escolhido - os Índices de 94 Resíduos de Embalagens (IRE's)

5.5.1. Os Índices de Resíduos de Embalagens (IRE's) 101

6. CONSIDERAÇÕES FINAIS - CONCLUSÕES E SUGESTÕES PARA TRABALHOS FUTUROS

7. REFERÊNCIAS BIBLIOGRÁFICAS

APÊNDICE I - Questionário $\quad 116$

APÊNDICE II - Normas da ABNT - Associação Brasileira de Normas

Técnicas - relativas às embalagens (até janeiro de 2005)

APÊNDICE III - Normas da série ISO 14000 em vigor (até maio de 2005) 128 


\section{INTRODUÇÃO}

Os sistemas de produção em série, surgidos por ocasião da Revolução Industrial, podem ser considerados o marco inicial do processo de evolução das embalagens. $\mathrm{O}$ aumento na complexidade dos processos produtivos acabou por tornar necessária a utilização de embalagens de diversos materiais e formas. As embalagens passaram, no decorrer da História, a ser empregadas não só para acondicionar o produto final, mas também durante as etapas de fabricação e transporte - matérias-primas, componentes diversos e mesmo produtos semi-acabados recebem alguma forma de embalagem atualmente.

No caso do Brasil, a Associação Brasileira de Embalagem - ABRE (2003a) considera o processo de substituição de importações, ocorrido após a Segunda Guerra Mundial, como o impulso mais significativo à industrialização do país e, portanto, à demanda por embalagens dos mais variados tipos e materiais ao longo do processo produtivo.

De qualquer forma, observa-se que fatores como o crescimento populacional, o fortalecimento de relações econômicas internas de blocos econômicos, como o Mercado Comum Europeu, e o processo de globalização da economia levam ao crescimento dos mercados; a possibilidade de explorar novos nichos econômicos representa oportunidades para exportação de produtos já existentes, bem como o desenvolvimento de novos produtos.

Ao mesmo tempo, o crescimento no consumo gera também aumento na demanda. Para atender a esse aumento, os setores industriais passam a ampliar sua produção, utilizando maiores quantidades de matérias primas e componentes de diferentes tipos; passam, desse modo, a receber mais embalagens.

Observa-se a seguinte seqüência de eventos no processo de produção:

- na fabricação, com o recebimento de insumos, constituídos pelas matériasprimas e componentes em geral, há indiretamente, o recebimento de embalagens. Esta etapa, portanto, gera resíduos de forma direta - como cavacos de usinagem, fluidos de corte e outros efluentes - e também de forma indireta, como os resíduos de embalagem, que também requerem tratamento e disposição adequada.

- no transporte, fatores como a necessidade de proteger os produtos, acabados ou mesmo semi-acabados, também tornam imprescindível a presença de embalagens. 
Estas, após sua utilização, podem ser transformar em resíduos que também precisarão ser tratados e dispostos adequadamente.

Atualmente, tornou-se imperativo analisar o problema da geração de resíduos sólidos, identificando e propondo medidas para reduzir e otimizar o consumo de embalagens, não apenas para o produto final, mas também ao longo do processo produtivo, durante as fases intermediárias de fabricação e transporte. Isto porque, além da crescente quantidade de embalagens geradas, a grande variedade de materiais utilizados implica na necessidade de se ter diferentes tratamentos e destinações adequadas para esses resíduos.

Diversas formas de gerenciamento de resíduos sólidos, que serão apresentadas em detalhes adiante, têm sido empregadas na tentativa de resolver a questão dos resíduos industriais. Historicamente, observam-se marcantes mudanças de paradigma no que diz respeito à forma de se gerenciar resíduos. A mais recente delas constitui uma tendência a priorizar a redução na geração de resíduos, com o emprego das chamadas tecnologias limpas, visando sobretudo à prevenção da poluição. JACKSON (1993) alerta para o fato de que a mudança de paradigma identificada na forma de gerenciamento das questões ambientais do processo de produção pode causar transtornos e períodos de indefinição no meio industrial; lembra, no entanto, que o período de contradições e instabilidades resultantes desta mudança pode ser abreviado por intervenções no processo, que consistem em suprir a indústria de informações e orientações sobre o novo paradigma a ser adotado.

No entanto, os estudos sobre as possibilidades de prevenção da poluição no ambiente industrial dão ênfase aos resíduos gerados diretamente no processo de fabricação como vazamentos de fluidos, cavacos de usinagem e efluentes de processos em geral. Ao mesmo tempo, os estudos e exemplos de prevenção da poluição aplicada às embalagens, como os descritos por JACKSON (1993) e BISHOP (2000) têm seu foco nas embalagens de bens de consumo, isto é, foram exemplificadas as possibilidades de prevenção da poluição apenas no caso de embalagens destinadas a acondicionar o produto final.

Evidentemente, um estudo sobre minimização de resíduos na indústria deve incluir a análise das possibilidades de prevenção da poluição por embalagens. Ainda são, portanto, necessárias pesquisas mais aprofundadas sobre a parcela de resíduos sólidos gerados no processo produtivo constituídos pelas embalagens que contiveram componentes, peças e produtos semi-acabados. Mais especificamente, devem ser 
realizadas avaliações sobre as possibilidades e resultados da aplicação dos conceitos de prevenção da poluição a essa parcela de resíduos gerados em indústrias.

É neste quadro que o trabalho proposto vem se inserir: a necessidade de suprir o setor de informações sobre o novo paradigma de gerenciamento de resíduos e, ao mesmo tempo, de contribuir para equacionar o problema representado pelas embalagens no meio industrial. 


\section{OBJETIVOS}

O objetivo geral do trabalho consistiu em se analisar a aplicabilidade do conceito de prevenção da poluição à questão das embalagens de uso industrial. Para tal, considerou-se inicialmente, uma série de definições relativas a embalagens, bem como a linha evolutiva dos conceitos de gerenciamento de resíduos sólidos, da disposição não controlada à prevenção da poluição, apontando a presença desta última em normas e regulamentos atualmente vigentes. Por fim, buscou-se a obtenção de dados práticos relacionados ao tema, através de estudo de caso.

Mais especificamente, os objetivos foram:

1) realizar uma análise comparativa de leis, normas e resoluções referentes às embalagens, no Brasil e em alguns países do mundo, de forma a situar o país quanto à questão do gerenciamento de resíduos, em particular os resíduos de embalagens.

2) analisar a forma de gerenciamento adotada em uma empresa montadora, identificando medidas que tenham contribuído para a prevenção da poluição por resíduos de embalagens;

3) realizar um levantamento da parcela de resíduos associada a embalagens e eventualmente gerada durante o processo de produção de um produto previamente escolhido:

- analisar, qualitativa e quantitativamente, esta parcela de resíduos, quanto ao tipo de material descartado: papel, plástico, metais, madeira, outros;

- em vista das informações obtidas, propor medidas que contribuam para o gerenciamento, com vistas à prevenção da poluição, como a adoção e determinação de indicadores relativos aos resíduos considerados. 


\section{REVISÃO BIBLIOGRÁFICA}

O conceito de prevenção da poluição por embalagens é simples conseqüência das chamadas "tecnologias limpas", que têm representado uma mudança na forma de se realizar o gerenciamento das questões ambientais nas empresas. Esta mudança em direção à prevenção da poluição atende ao mesmo tempo à necessidade de redução e prevenção de impactos ambientais resultantes direta ou indiretamente dos processos produtivos, e à busca da competitividade pelas empresas, pela redução de custos que proporciona.

Ferramentas desenvolvidas recentemente, como a análise de ciclo de vida, aliadas à criteriosa classificação dos resíduos a serem gerenciados, podem contribuir de forma decisiva para o sucesso de programas de prevenção da poluição por embalagens em indústrias. Tais programas podem ainda incluir auditorias ambientais, para identificar oportunidades para redução na geração de resíduos, bem como a constituição de equipes internas multiprofissionais que garantam sua manutenção.

\subsection{Embalagem}

\subsubsection{Definições}

Moura \& Banzato (1997) apresentam uma série de definições aplicáveis à embalagem; afirmam, porém, que todas elas de modo geral refletem a interface de determinado consumidor, intermediário ou final, com a embalagem:

- a palavra embalagem sugere, de modo geral, um aspecto físico; neste sentido, pode ser definida como o material ou meio protetor que permite que uma mercadoria chegue ao consumidor em ótimas condições e, em alguns casos, garanta a sua apresentação e estado de conservação no momento do uso.

- pode-se, também, considerar a embalagem como um processo, uma seqüência de operações e nesse sentido, pode-se definir embalagem como sendo a técnica de preparar as mercadorias para distribuição, podendo incluir a limpeza, secagem, preservação, empacotamento, marcação e unitização.

Unitização de cargas é a reunião de certa quantidade de volumes isolados em uma única unidade de carga, de dimensões padronizadas ou não, cuja movimentação é 
feita de forma mecanizada (MOURA \& BANZATO, 1997). Assim, as chamadas cargas unitizadas são, na verdade, a reunião de produtos, embalados individualmente ou não, em uma grande embalagem comum.

Para Souza (2000), as definições de embalagem variam de acordo com a função ou o significado a ela atribuído num determinado contexto técnico-econômico e sóciocultural, em um certo momento histórico.

\subsubsection{Funções da embalagem}

A bibliografia consultada apresenta diferentes formas de categorizar as funções da embalagem.

O Manual para Planejamento de Embalagens (1976) atribui à embalagem as funções de quantificação, proteção e qualificação. Para Moura \& Banzato (1997), essas funções são a contenção, a proteção, a comunicação e a utilidade. Pinatti (1999) aponta a proteção, quantificação, qualificação e comercialização. Já segundo Hope (2004), a uma embalagem podem ser atribuídas as funções de proteção, utilidade e comunicação.

Ao discorrerem sobre as funções que enumeram, os textos acabam gerando um consenso de que a embalagem deve ser capaz não só de conter o produto, mas de garantir uma proteção adequada a ele, bem como ser fonte de informações que facilitam a manipulação e o transporte do conjunto produto-embalagem; nos casos onde é necessário, deve constituir um incentivo adicional à compra, valorizando o produto através de uma boa apresentação.

De modo sucinto, tem-se, a partir das referências, notadamente Moura \& Banzato (1997):

Contenção do produto: a embalagem deve servir de receptáculo para as unidades do produto, impedindo que este transborde, vaze ou escape da embalagem.

Proteção: a embalagem deve preservar as qualidades e características iniciais do produto que contém, protegendo-o dos perigos impostos pela manipulação, movimentação, estocagem, transporte e condições atmosféricas, desde o acondicionamento até a utilização. Em geral, consideram-se dois tipos de proteção: mecânica - contra os efeitos de choques, vibrações, aceleração da gravidade (fator G), compressão ou empilhamento - e físico-química - contra os efeitos de agentes como oxidação, temperatura, umidade e radiação solar.

Fonte de comunicação: a embalagem também tem a função de levar informações e mensagens através de suas formas, dimensões, cores, gráficos, símbolos e impressões. 
Os dados contidos na embalagem podem ser referentes não apenas ao produto quantidade e qualidade, procedência, destinação e instruções para manipulação - como também à própria embalagem: se ela é reciclável ou retornável, composta ou não de materiais reciclados, e qual a porcentagem destes.

Os autores lembram ainda que essas funções podem ser atribuídas em maior ou menor grau a qualquer tipo de embalagem, independentemente do produto ou da indústria envolvida, e sempre se inter-relacionam na composição de uma embalagem, seja ela de consumo ou de transporte.

Em outras palavras, deve existir na prática um compromisso entre as funções que são atribuídas a uma certa embalagem, bem como ter sempre em mente os custos advindos do atendimento desses requisitos. É preciso considerar as características do produto de modo a enfatizar certas funções: alguns produtos podem requerer embalagens com maior ênfase na proteção, enquanto que outros necessitam de embalagens que enfatizem a comunicação ou os aspectos estéticos.

Sousa (2000) reagrupa as funções da embalagem em outros três tipos: tecnológica, mercadológica e econômica.

Função tecnológica: associada ao acondicionamento e proteção do produto.

Além do aspecto qualitativo - qual o tipo de embalagem a ser empregado -, o acondicionamento envolve também aspectos quantitativos, uma vez que, a quantidade do produto a ser contida em uma embalagem determina o volume e dimensões mínimas desta. Já a proteção deve considerar riscos de natureza:

- mecânica: choques e batidas;

- climática: variações de clima e umidade;

- biológica: ataques de fungos, roedores, insetos;

- química: ataques de substâncias, mudanças nas propriedades do produto.

Função mercadológica: relacionada à apresentação, identificação e informação. Apresentação: aspectos estéticos, que podem estimular a compra, nos casos de embalagens que expõem produtos à venda.

Identificação e informação: informações sobre o produto e a forma de manipulação, transporte, abertura e fechamento da embalagem.

É importante notar que os aspectos de apresentação e identificação relacionamse não apenas ao produto contido na embalagem como também à própria embalagem. 
Função econômica: avaliação dos custos associados à embalagem, da seleção de matérias-primas para sua fabricação até à disposição final. A atenção dada a certas características da embalagem é necessariamente balizada pelos aspectos econômicos. Atualmente, devem ser considerados também os custos associados ao tratamento das embalagens após o uso, e à possível reciclagem ou reutilização.

Desse modo, estabelecem-se as seguintes relações:

- Função tecnológica: relacionada à contenção, proteção;

- Função mercadológica: relacionada à comunicação, informação, promoção;

- Função econômica: relacionada aos custos, produtividade, lucratividade.

O quadro a seguir sintetiza as visões dos autores consultados.

Quadro 1 - As funções da embalagem

\begin{tabular}{|c|c|c|c|c|c|c|}
\hline & $(1)$ & $(2)$ & (3) & (4) & (5) & \\
\hline Proteção & $\mathrm{X}$ & $\mathrm{X}$ & $\mathrm{x}$ & $\mathrm{x}$ & \multirow{4}{*}{ tecnológica } & \multirow{7}{*}{ econômica } \\
\hline Contenção & & $\mathrm{x}$ & & & & \\
\hline Quantificação & $\mathrm{X}$ & & $\mathrm{X}$ & & & \\
\hline Qualificação & $\mathrm{X}$ & & $\mathrm{X}$ & & & \\
\hline Comunicação & & $\mathrm{x}$ & & $\mathrm{X}$ & \multirow{2}{*}{ mercadológica } & \\
\hline Comercialização & & & $X$ & & & \\
\hline Utilidade & & $\mathrm{X}$ & & $\mathrm{X}$ & $\begin{array}{l}\text { tecnológica e } \\
\text { mercadológica }\end{array}$ & \\
\hline
\end{tabular}

fontes: (1): Manual para Planejamento de Embalagens (1976); (2) MOURA \& BANZATO (1997); (3) PINATTI (1999); (4) HOPE (2004); (5) SOUSA (2000)

Segundo Dean (1993) apud Sousa $(2000)^{1}$, as funções tecnológica, mercadológica e econômica devem ser atendidas durante toda a vida do produto e da própria embalagem, desde sua fabricação, consumo e até a disposição final, cobrindo as etapas de estocagem, carga e descarga, transporte, exposição, utilização e descarte. Uma vez que o produto tenha sido usado ou removido da embalagem, o principal objetivo desta foi cumprido. Como dispor a embalagem se torna, então, uma questão ambiental.

É possível elaborar este raciocínio e afirmar que o gerenciamento de embalagens e resíduos de embalagens deve abranger não apenas do planejamento à disposição final, mas também considerar as possibilidades de recuperação, reutilização e reciclagem, e

${ }^{1}$ DEAN, D. (1993). Packaging principles and practice. Institute of Packaging. Melton Mobray apud SOUSA, op. cit. 
que o próprio planejamento deve prever as possibilidades de redução na quantidade de resíduos representados pela embalagem após o fim de sua vida útil.

\subsubsection{Classificação das embalagens}

São apresentadas as formas de classificação de embalagens quanto à função ou ao grau de contato, à finalidade, à movimentação e à utilidade.

\section{$\underline{\text { Função }}$}

Este tipo de classificação diz respeito às "camadas" que podem ser identificadas no processo de acondicionamento de um produto qualquer, ou nas palavras de Sousa (2000), ao grau de contato que a embalagem tem com o produto. Dessa forma, tem-se:

- embalagem primária: embalagem que contém o produto, sendo a medida da produção e de consumo; também pode ser a unidade de venda no varejo;

- embalagem secundária: acondiciona e protege a embalagem primária; por exemplo, uma bandeja de cartão com filme termoencolhível, para acondicionar caixas de leite longa vida.

- embalagem terciária: é o caso das caixas de madeira, papelão, plástico ou outro material. A combinação da embalagem primária e secundária acaba sendo a medida de venda ao atacadista.

- embalagem quaternária: envolve o contenedor, recipiente maior projetado de modo a facilitar a movimentação e a armazenagem.

- embalagem de quinto nível: embalagens especiais para envio a longa distância, ou unidade conteinerizada, isto é, contida em contêineres, equipamentos maiores para operações de transporte (MOURA \& BANZATO, 1997).

\section{Finalidade}

Embalagem de consumo: leva o produto ao consumidor. Sua forma de apresentação é estudada e projetada de modo a ser agradável, prática e atraente. Para tal, requer definição de dimensões, forma, cor geral e aspecto gráfico. Em geral, precisa de um acondicionamento para as operações de movimentação e armazenagem.

Embalagem expositora: utilizada para transportar o produto e também para expô-lo. Deve, portanto, representar um estímulo para que a venda seja efetuada. É usada, sobretudo, para as mercadorias de vendas diárias; mantém as embalagens de consumo unidas e protegidas as durante o transporte e a movimentação. Também 
precisa ser empilhável, estar pronta para venda, exigindo o menor esforço para abri-la, ter um texto e decoração atrativa, permitir a coleta da embalagem de consumo e ser fácil de manipular, tanto em peso quanto em volume.

Embalagem de distribuição física: protege o produto, suportando as condições físicas encontradas no processo de distribuição física: as operações de carga, transporte, descarga e entrega. Além disso, fornece identificação do conteúdo e instruções especiais para utilização, e deve apresentar facilidade para abrir, desembalar, fechar novamente, reutilizar ou descartar. Pode ser uma embalagem primária (uma industrial, como um tambor, por exemplo), ou secundária, isto é, uma embalagem de produtos préembalados em unidades menores.

Embalagem de transporte e exportação: protege um produto durante os diversos modos de transporte - manuseios, movimentações mecânicas e estocagens -, geralmente facilitando tais operações. Pode acompanhar o produto desde a fábrica até o destinatário final, como no caso de máquinas e geladeiras, ou desde a fábrica até um centro de distribuição, como um supermercado, por exemplo; certas embalagens de venda ao consumidor, como tambores, podem ser consideradas embalagens de transporte. Permite na maior parte dos casos, a armazenagem de duração mais ou menos longa, quer antes da expedição, quer durante as escalas, ou ainda no decurso do transporte pelos vários entrepostos e armazéns.

Embalagem industrial ou de movimentação: protege o material durante a estocagem e a movimentação dentro de um conjunto industrial, entre fábricas de uma mesma empresa ou entre fornecedores e clientes. Caracteriza-se por ser de uso repetitivo: é movimentada com freqüência, razão pela qual precisa ser robusta para suportar impactos de empilhadeira, batidas no solo e transporte em carretas ou caminhões. Conta com dispositivos para ser erguida e içada, além de encaixes autosuportantes.

Embalagem de armazenagem: protege o material de agentes agressivos externos:

- Físicos: choques, variações de temperatura, umidade e luminosidade;

- Químicos: ação de ácidos, bases e do próprio ar;

- Biológicos: ação de parasitas como bolores, bactérias, insetos, roedores. 


\section{$\underline{\text { Movimentação }}$}

\section{Embalagem de movimentação manual}

Embalagem de movimentação mecânica: quando o volume ou o peso da embalagem tornar necessário o uso de equipamento mecânico.

\section{$\underline{\text { Utilidade }}$}

Embalagem retornável: retorna à origem, geralmente para sua utilização industrial. Quando bem projetada, tem uma longa vida de uso; em geral, leva a marca de seu proprietário. Apresenta as seguintes características:

- requer investimento e, portanto, custo adicional;

- pode ser desmontável, ocupando menos espaço quando vazia;

- implica em custo de transporte, para retorno;

- requer controles de expedição e recebimento;

- é necessária documentação fiscal para o seu transporte;

- requer manutenção e conservação constante;

- é obrigatório, por força de lei, que a empresa a identifique com seu nome e numeração seqüencial, para controle. Por exemplo: "Propriedade da (nome da empresa)".

Embalagem não-retornável: utilizada em um único ciclo da distribuição; em alguns casos, é reaproveitada pelo destinatário. Apresenta as seguintes características:

- menor custo - é considerada despesa, e não investimento;

- dispensa controles e documentação fiscal;

- é leve e, portanto, implica em menor custo de transporte;

- deve resistir a repetidos ciclos de distribuição e armazenagem.

Pinatti (1999) apresenta uma outra forma de classificação, relacionada à destinação final da embalagem, após esgotadas as possibilidades de uso: quanto ao destino ambiental, diz o autor, as embalagens podem ser recicláveis ou não-recicláveis.

- embalagem reciclável: após o descarte e a coleta seletiva, permite a reciclagem do material, do ponto de vista econômico e ambiental.

- embalagem não-reciclável: não permite a reciclagem, por problemas como composição dos materiais, contaminação externa, uso hospitalar, químico, radioativo ou inviabilidade econômica. Algumas podem ser incineradas, constituindo fonte de energia. 
Em síntese, tem-se:

Quadro 2 - Classificação de embalagens

\begin{tabular}{|c|c|c|c|c|}
\hline Função & Finalidade & Movimentação & Utilidade & $\begin{array}{c}\text { Destino } \\
\text { ambiental }\end{array}$ \\
\hline primária & de consumo & $\begin{array}{c}\text { movimentada } \\
\text { mecanicamente }\end{array}$ & retornável & reciclável \\
\hline secundária & expositora & $\begin{array}{c}\text { movimentada } \\
\text { manualmente }\end{array}$ & $\begin{array}{c}\text { não } \\
\text { retornável }\end{array}$ & $\begin{array}{c}\text { não } \\
\text { reciclável }\end{array}$ \\
\hline terciária & $\begin{array}{c}\text { de distribuição } \\
\text { física }\end{array}$ & - & - & - \\
\hline quaternária & $\begin{array}{c}\text { de transporte e } \\
\text { exportação }\end{array}$ & - & - & - \\
\hline $\begin{array}{c}\text { de quinto } \\
\text { nível }\end{array}$ & $\begin{array}{c}\text { industrial ou de } \\
\text { movimentação }\end{array}$ & - & - & - \\
\hline- & de armazenagem & - & - & - \\
\hline
\end{tabular}

\subsubsection{Materiais para embalagens}

\section{$\underline{\text { Madeira }}$}

Como lembra Moura (1983), a madeira foi, durante séculos, o material tradicional para embalagens. Devido à devastação das matas e ao aparecimento de materiais concorrentes, como o alumínio, plástico e papel, a madeira perdeu espaço no mercado. Permanece, no entanto, como material de destaque na utilização em embalagens, em razão de derivações, como o compensado, de concepções estruturais, como a caixa desmontável, e de embalagens compostas por combinações da madeira com outros materiais, situações nas quais ela contribui com suas características de rigidez e resistência à tração. Segundo o autor, os principais tipos de embalagens de madeira são:

- Caixas industriais: compostas por tábuas que podem ser serradas em diversas espessuras, fixadas por pregos. Apresentam rigidez e são empilháveis; utilizadas para equipamentos, máquinas e produtos de alto e médio valor.

- Engradados abertos: formados por ripas com espaçamentos diversos; são mais leves, oferecendo menor proteção; utilizados para acomodar máquinas e equipamentos de grande peso, e que não requeiram proteção contar intempéries.

- Engradados fechados: compostos por tábuas madeira serrada, fixada por pregos ou parafusos, apresentam resistência ao manuseio. Acondicionam equipamento que requer maior proteção, inclusive contra intempéries. 
- Caixas de compensado: o compensado é, em poucas palavras, um sanduíche, constituído por três folhas de pinho, de espessuras variáveis, coladas entre si por um adesivo à base de plástico. A adesão das folhas é obtida por prensagem em prensas hidráulicas, aquecidas a vapor. Caixas fabricadas com este material são mais leves do que as caixas comuns de madeira maciça, resistem a quedas, podem absorver choques, são de fácil manipulação e podem ser desmontadas, reduzindo em muito seu volume. São utilizadas para transportar máquinas e equipamentos.

Além destes tipos, há ainda os tonéis e barris e barricas. Rígidos e empilháveis, podem ser feitos em madeira serrada ou compensado; acondicionam produtos secos, pastosos ou líquidos.

\section{Papel e papelão}

Material econômico e muito versátil, tem baixo custo, baixo peso e facilidade de processamento. O papel ondulado é o material mais comumente usado para embalagens; popularmente chamado de papelão, este material tem uma camada intermediária de papel entre suas partes exteriores, disposta em ondulações, na forma de uma sanfona (CEMPRE, 2004a).

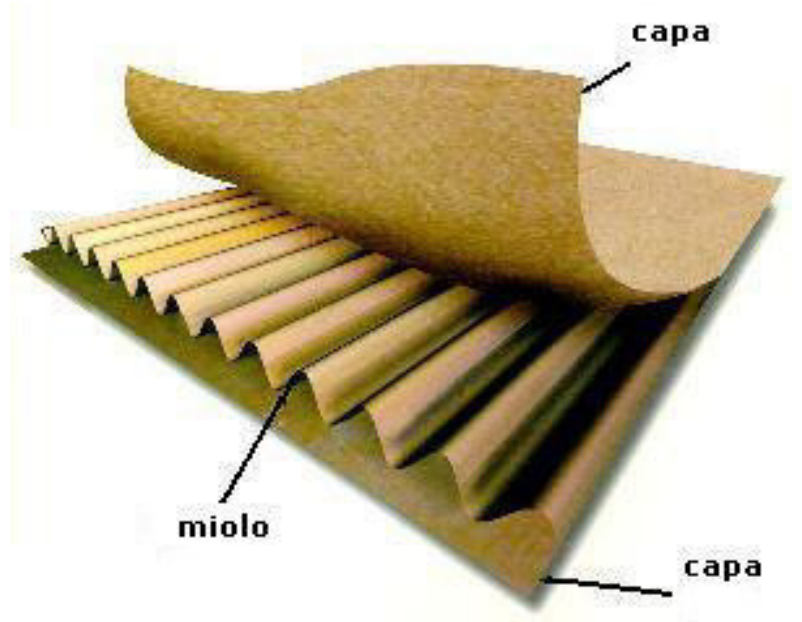

Figura 1 - Estrutura do papel ondulado (ABPO, 2004)

O papelão ondulado é utilizado na fabricação de diversos tipos de caixas para transporte de produtos para fábricas, depósitos, escritórios e residências. Estas caixas, segundo Moura \& Banzato (1997), mostram-se mais leves, manuseáveis e resistentes a choques do que as caixas de madeira. 
$\underline{\text { Metal }}$

A folha de flandres, o ferro e o alumínio são matérias-primas básicas na fabricação de embalagens de metal, em geral constituídas de um corpo com fundo e tampa. De modo geral, as embalagens metálicas caracterizam-se pela rigidez e pelo fechamento hermético; tampas removíveis possibilitam o acondicionamento adequado de produtos que permanecem na embalagem enquanto utilizados. A inclusão de alças, para latas de tintas, por exemplo, facilita a manipulação. (Manual para Planejamento de Embalagens, 1976).

A folha de flandres é uma folha de aço recoberta nas duas faces por uma camada de estanho. Seu maior uso é na indústria de alimentação, porém pode ser empregada para produtos não-alimentícios, como tintas, óleos vegetais e combustíveis, graxas, ceras, e vários produtos secos (MOURA \& BANZATO, 1997). Latas de aço são resistentes e versáteis: podem conter desde produtos delicados, como balas e biscoitos finos, até produtos de uso industrial, como os óleos lubrificantes e tintas navais (ABEAÇO, 2004).

O alumínio é obtido através da eletrólise da alumina pura, obtida do tratamento da bauxita (variedade natural e impura da alumina). É atóxico e impermeável a gases, vapores e odores estranhos; é laminável em várias espessuras. Quanto mais puro o alumínio, maior sua resistência à corrosão; as impurezas do alumínio são as da bauxita: o silício e o ferro (MOURA \& BANZATO, 1997).

\section{$\underline{\text { Vidro }}$}

Com o vidro são produzidas embalagens de baixo custo, higiênicas e resistentes ao tempo, ao calor e à ação de ácidos e bases. Não impede a passagem de luz e de outras radiações, como o ultravioleta e o infravermelho, porém esse inconveniente é contornado com o uso de vidros coloridos, obtidos com a adição de pigmentos ou matérias-primas impuras. É utilizado em garrafas, potes e frascos; seu transporte requer a utilização de outra embalagem externa de papelão ou madeira; o que faz com que se perca até $25 \%$ do espaço útil da embalagem final (MOURA, 1983).

O vidro vem, já há algum tempo, perdendo espaço para outros tipos de material, notadamente o plástico rígido, que permite obter embalagens mais leves e resistentes a choques. 


\section{Fibras naturais}

A juta e o algodão são as matérias-primas empregadas. Os sacos de juta são resistentes e facilmente empilháveis; suas propriedades higroscópicas impedem o apodrecimento dos produtos ensacados. Sua reutilização é limitada a duas ou três vezes. Os sacos de algodão são pouco resistentes à umidade, ácidos e bases (MOURA, 1983).

\section{$\underline{\text { Plásticos }}$}

Apresentam-se nas formas flexíveis, rígidas, semi-rígidas ou em espuma. Os filmes flexíveis são em geral associados a papéis ou cartões, formando embalagens leves. Podem se empregados também na confecção de sacos. Plásticos rígidos e semirígidos resultam em embalagens com baixo custo, boa resistência e rigidez, o que lhes permitiu tomar o lugar de alguns tipos clássicos de embalagens (MOURA, 1983). O plástico rígido compõe cerca de $77 \%$ das embalagens plásticas no Brasil, como garrafas, potes e diversos outros recipientes. É também matéria-prima básica de bombonas, fibras têxteis, tubos e conexões, calçados, eletrodomésticos, além de baldes, utensílios domésticos e outros produtos (CEMPRE, 2004b).

Os tipos de plásticos mais comumente utilizados são:

Polietilieno (PE): pode ser de baixa densidade (PEBD) e de alta densidade (PEAD). O PEBD é a matéria plástica mais empregada em embalagem. É de baixo custo, flexível, resistente a choques e fácil de moldar; não resiste a temperaturas acima de $80^{\circ} \mathrm{C}$. O PEAD é rígido, resistente a choques, porém inflamável. É aplicado na fabricação de frascos quimicamente inertes, para acondicionar, detergentes, óleos e graxas (Manual para Planejamento de Embalagens, 1976).

O polietileno de baixa densidade pode ser empregado sob a forma de filme flexível; para peças como bombonas e tanques, utiliza-se o polietileno de alta densidade (MOURA \& BANZATO, 1997).

Polipropileno (PP): pode atingir um alto grau de transparência. Resiste a altas temperaturas, sendo frágil nas baixas. É pouco permeável à água e à umidade em geral; pode acondicionar óleos e graxas. Apresenta bom rendimento na produção de filmes e recipientes moldados por injeção e sopro (Manual para Planejamento de Embalagens, 1976).

Poliestireno (PS): é de fácil moldagem, sensível a hidrocarbonetos, óleos e solventes. Uma variante conhecida deste material é o poliestireno expandido (PSE), popularmente conhecido como isopor. Trata-se de um plástico celular rígido, resultante 
da polimerização do estireno em água; o produto final é composto de pérolas de até 3 milímetros de diâmetro. No processo de transformação, essas pérolas são submetidas à expansão em até 50 vezes o seu tamanho original, através de vapor, fundindo-se e moldando-se em formas diversas. O poliestireno expandido é utilizável em embalagens industriais, artigos de consumo, na agricultura e na construção civil (ABRAPEX,2004).

Cloreto de polivinila (PVC): É de grande transparência. O Manual para Planejamento de Embalagens (1976) apresenta dois tipos: rígido e flexível.

O PVC rígido é praticamente impermeável, porém não resiste a temperaturas altas ou baixas. Necessita de estabilizantes térmicos para evitar envelhecimento; não é inflamável, mas desprende ácido clorídrico ao se decompor. O PVC flexível tem flexibilidade comparável à da borracha. Tem aplicações importantes, segundo o Manual, no acondicionamento de líquidos não alimentícios, em cintas de filme, garrafas e em filmes retráteis, sendo mais transparente que os filmes de polietileno.

Poliuretano (PU): é, em geral, utilizado sob a forma de espuma; esta pode ser flexível, semi-rígida, rígida ultraleve ou rígida (Manual para Planejamento de Embalagens, 1976).

\subsubsection{Paletes, caçambas e contêineres}

Neste item, são discutidos alguns tipos particulares de recipientes, especialmente utilizados em indústrias para facilitar o transporte, movimentação e armazenamento de cargas unitizadas.

Conforme Moura \& Banzato (1997), o palete é uma plataforma disposta horizontalmente para carregamento. Constituída de vigas ou blocos, de face simples, dupla ou com reforços sobre os apoios, permite o arranjo ou agrupamento de materiais, possibilitando o manuseio, estocagem, movimentação, por empilhadeira ou outro sistema, e transporte como se se tratasse de uma única unidade; quando os componentes e materiais são resistentes e não correm risco de deterioração, os paletes são empilhados diretamente uns sobre os outros.

Quanto ao uso, um palete pode ser:

- descartável: utilizado em uma única operação

- sem retorno: não retorna ao ponto inicial da operação de transporte; pode ser descartável ou ser de uso repetitivo no destinatário;

- de uso repetitivo: destinado a várias operações de transporte ou estocagem ente o embarcador e o destinatário ou vice-versa. 
No caso dos paletes retornáveis, há o "pool” ou intercâmbio de paletes. Neste esquema de trabalho, os fornecedores e usuários trocam entre si um certo número de paletes durante as operações de distribuição: o usuário, na compra de certo lote de componentes, recebe também os paletes. Este intercâmbio se baseia em um contrato legal que inclui também os transportadores. O custo de propriedade dos paletes por parte da empresa de expedição ou usuários individuais é sensivelmente reduzido, havendo ainda outros fatores de economia em razão da padronização em larga escala e do melhor aproveitamento do equipamento de transporte. Também é empregado o sistema de compra direta do palete; neste caso, ele é adquirido juntamente com os materiais (MOURA \& BANZATO, 1997)

Segundo Moura (1983), os paletes podem ser feitos de:

- madeira ou derivados (aglomerado, compensado): são os mais comuns;

- plástico: nos casos em que se requer grande higiene ou segurança, constituem alternativa aos de madeira; são muito mais caros que estes, porém mais limpos - não soltam lascas e nem são atacados por insetos; são ainda, mais duráveis, ainda que tendam a rachar quando submetidos a esforços exagerados;

- fibra de vidro: retornáveis, são mais resistentes que os plásticos e podem ser consertados com baixo custo;

- papelão: mais leves que os de madeira, são facilmente danificáveis, o que prejudica sua reutilização;

- materiais metálicos: são necessários quando o peso das cargas é excessivo, as temperaturas são altas e o trabalho é pesado.
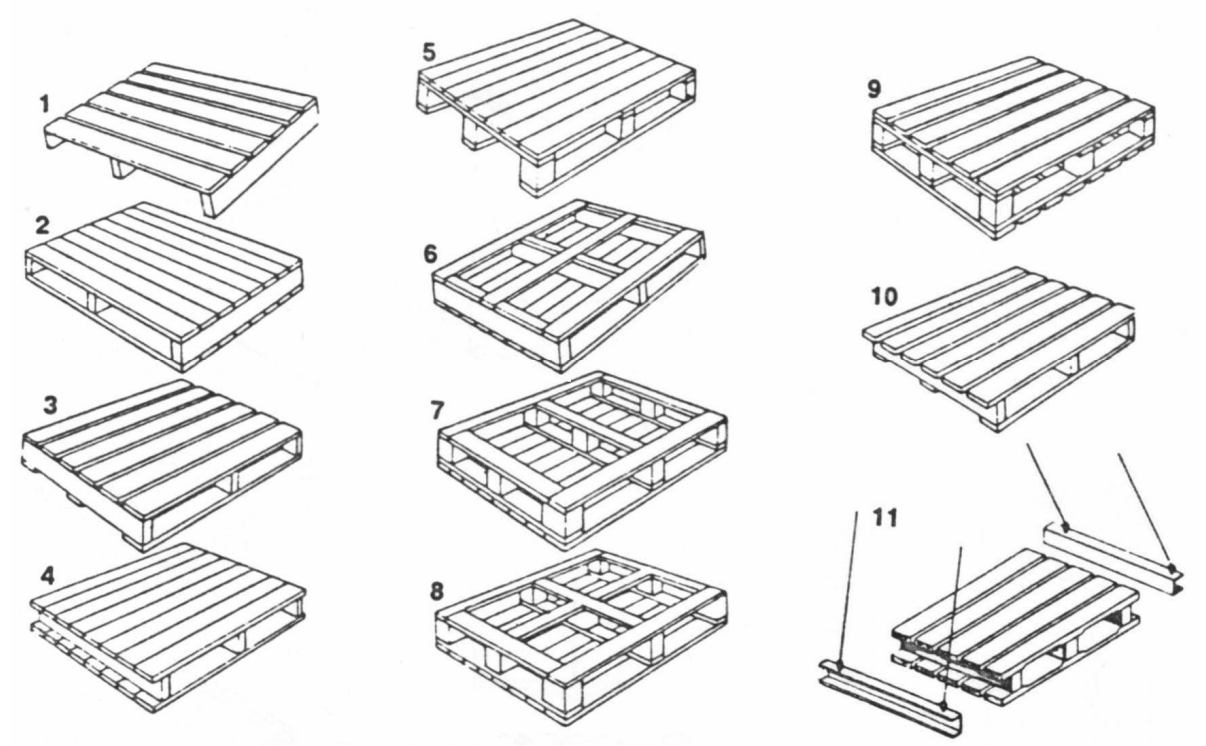

Figura 2 - Paletes: soluções construtivas (MOURA \& BANZATO, 1997) 
Os contenedores ou caçambas industriais, conforme MOURA (1983), permitem a movimentação de peças a granel (parafusos, porcas e pequenas peças em grandes quantidades), tendo o mesmo conceito do palete, isto é, podem ser apanhados por algum equipamento. São em geral, de madeira ou metal. As caçambas são utilizadas para transporte interno e externo e armazenagem de materiais.

Os contêineres são equipamentos de fácil movimentação, para repetidas utilizações. Podem ser estacionados em pátios e dispensam outro tipo de embalagem para proteção da carga. São de tamanhos variáveis, fabricados em chapas de aço galvanizado, madeira ou fibra. Alguns são desmontáveis (MOURA, 1983).

\subsubsection{Acessórios para embalagens}

Os resíduos de embalagens são constituídos não apenas pelas próprias embalagens, mas por seus acessórios e complementos. Junto com a embalagem, são recebidos acessórios para seu fechamento ou fixação, informação e proteção do conteúdo, além de substâncias como colas e tintas.

Acessórios para fechamento ou fixação: variam conforme o material que compõe a embalagem, e também com o grau de proteção contra sua abertura indesejada. Destacam-se grampos, pregos, arame, fitas de aço ou plásticas, fitas adesivas, barbante de fibras naturais ou sintéticas, filmes plásticos retráteis e linhas para costura. As fitas de aço ou plásticas, além de reforçarem embalagens, são utilizáveis para amarrar tubos e barras, facilitando seu transporte e manuseio.

Elementos de informação: rótulos, selos, inscrições que contêm informações sobre o conjunto embalagem-produto, como local de procedência, peso, dimensões e cuidados especiais na movimentação, transporte e armazenagem. Requerem uso de tintas ou colas; Moura (1983) cita como adesivos mais comuns o silicato de sódio, a dextrina, a caseína e a cola de borracha.

Elementos de proteção: podem ser mencionados os divisores, que constituem o que Moura (1983) chama de acessório interno: são peças, em geral de papelão, destinadas a proteger a mercadoria no interior de uma caixa. Tais acessórios dividem o interior da caixa em compartimentos chamados de células. 

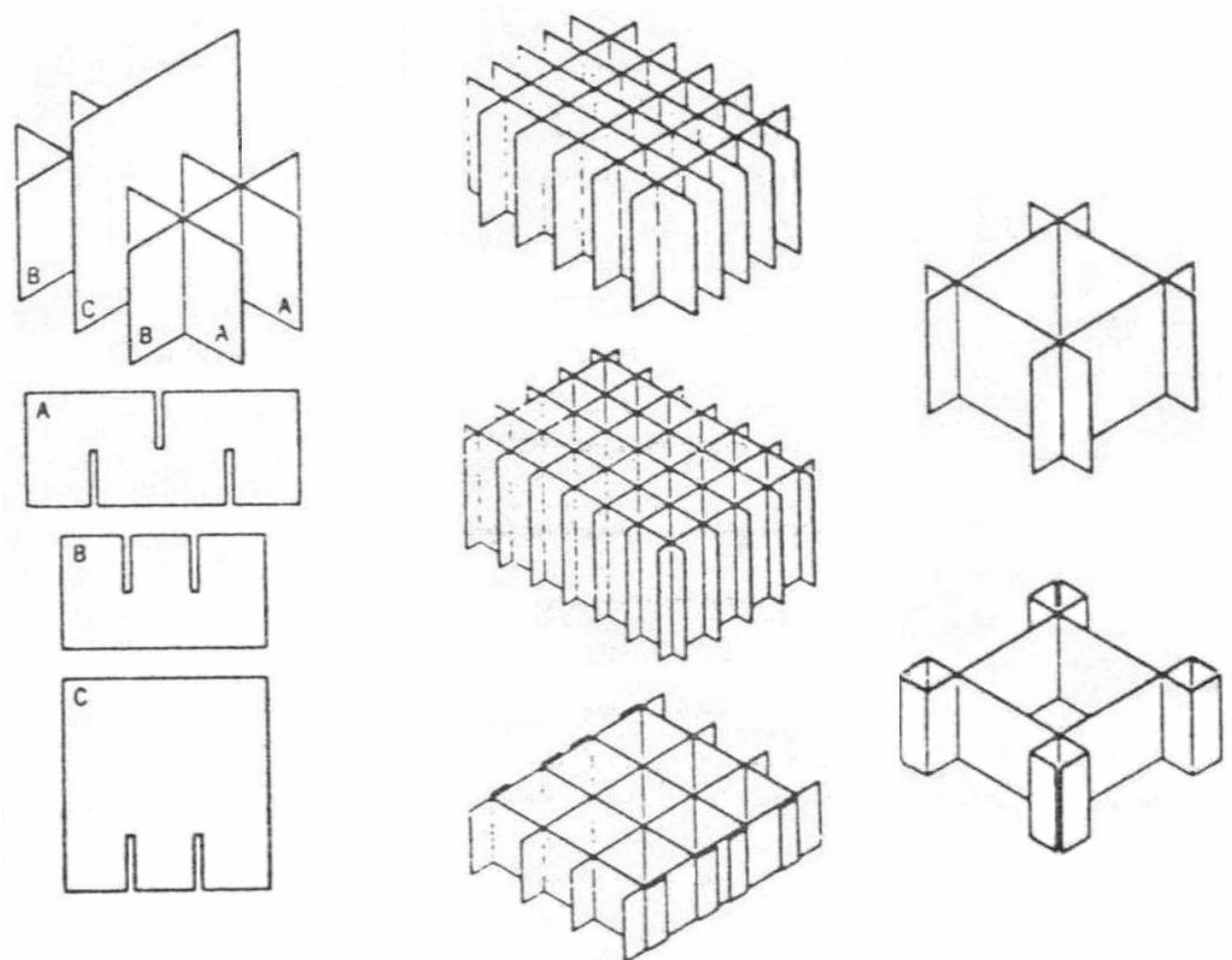

Figura 3 - Exemplo de montagem e tipos de divisores (MOURA, 1983)

Além dos divisores, há os calços e dispositivos variados para acolchoamento. Englobam desde materiais reutilizados, como jornais velhos e outras sobras de papel, até materiais mais sofisticados, como plásticos expandidos e espumas.

Dois exemplos comuns de plásticos expandidos são o chamado blister (bolha, em inglês), produzido por formação de vácuo a partir de plásticos, como o PVC, e o poliestireno expandido, moldado am diversas formas. As espumas mais comuns são as de poliuretano:

- flexíveis: servem de calço para objetos embalados;

- semi-rígidas: em calços para peças pesadas;

- rígidas ultraleves; acondicionam vidros, pequenos componentes elétricos;

- rígidas: utilizadas nos casos em que é necessário isolamento térmico (Manual para Planejamento de Embalagens, 1976).

No caso das cargas unitizadas, Moura (1983) cita a utilização de cintas metálicas ou plásticas e filmes termoplásticos. Estes se retraem quando aquecidos, possibilitando o enclausuramento dos objetos. 


\subsection{Embalagem de consumo final e embalagem de uso industrial}

Neste texto, para efeito de pesquisa, as embalagens serão consideradas principalmente segundo sua finalidade. Serão empregados fundamentalmente dois termos para agrupar e diferenciar as embalagens existentes:

Embalagem de consumo final: embalagem que acondiciona produtos levados ao consumidor final.

Embalagem de uso industrial: embalagem utilizada no ambiente industrial, em operações como armazenagem, movimentação e transporte, tanto dentro da empresa como entre empresas.

Os diferentes materiais, funções, modos de movimentação, utilidades e destinos ambientais apresentados anteriormente não serão ignorados: servirão para caracterizar os tipos de embalagens encontrados.

É necessário, neste ponto, discutir mais detalhadamente as diferenças entre as embalagens de uso industrial, que serão objeto da pesquisa e as embalagens de consumo final.

\subsubsection{Finalidades}

Na bibliografia consultada, é de opinião comum que as embalagens de consumo, especialmente as embalagens expositoras, que acondicionam e acompanham o produto até as gôndolas e balcões, devem ser projetadas cuidadosamente. De fato, os aspectos comunicativos podem não apenas transmitir informações, mas também contribuir para a promoção e venda do produto, constituindo o que Pinatti (1999) denomina "função comercialização" da embalagem: no caso da embalagem de consumo, os aspectos estéticos e formais podem aumentar o valor de mercado do produto, possibilitando a venda por si só.

Os aspectos estéticos (função mercadológica) são, assim, fundamentais para uma embalagem de consumo. Evidentemente, porém, os aspectos de proteção e contenção devem ser levados em consideração, pois este tipo de embalagem deve proteger o produto durante um certo tempo de armazenagem e exposição, até a compra e o consumo.

A embalagem de uso industrial, por sua vez, acondiciona produtos que já foram vendidos, portanto o estímulo à compra é praticamente desconsiderado. É utilizada para acondicionar e manter a integridade do produto durante as fases de transporte, 
armazenagem e movimentação interna. Os aspectos de contenção e proteção (função tecnológica) são os mais importantes nestes casos. Isto não significa, no entanto, que o aspecto visual seja irrelevante: pode ser importante que a embalagem apresente informações sobre sua manipulação, abertura, fechamento e cuidados no transporte. Os aspectos estéticos podem contribuir para a boa imagem da empresa fornecedora dos componentes em questão.

Em resumo, as diferenças entre tais embalagens resultam da diferente ênfase dada às funções tecnológica e mercadológica em cada caso.

\subsubsection{Fluxos das embalagens}

Conforme lembra o Manual para Planejamento de Embalagens (1976), a embalagem integra o processo de comercialização de um certo produto. Segue, desse modo, uma seqüência de etapas que recebe o nome de fluxo da embalagem.

O Manual descreve o seguinte fluxo para uma embalagem de consumo final:

- produção da embalagem, a partir da matéria-prima básica: madeira, areia, minérios e produtos químicos;

- acondicionamento do produto e fechamento da embalagem, e posterior estocagem do produto, já em embalagem de transporte ou não;

- despacho do produto, estocagem e expedição;

- distribuição, envolvendo estocagem, movimentação e transporte;

- venda: remanejo das embalagens de transporte, rearranjo das embalagens de consumo conforme as necessidades do tipo de venda; estocagem para posterior venda;

- consumo: compra e utilização do produto, com conseqüente esvaziamento da embalagem;

- disposição, reutilização ou reciclagem da embalagem.

Nota-se que a embalagem de consumo final é separada do produto que acondiciona, deixando de cumprir sua finalidade, no momento do consumo do produto final.

Para Moura \& Banzato (1997), essa seqüência de etapas é denominada sistema de embalagem; fazem parte do sistema de embalagem fornecedores de matéria-prima, transformadores, fornecedores de máquinas de embalar, fabricantes de produtos - os usuários da embalagem - projetistas e consultores, além de intermediários no sistema de distribuição, como transportadores, almoxarifados, atacadistas, varejistas e consumidores de produtos embalados. 
A embalagem de uso industrial, por sua vez, integra o processo de fabricação de um certo produto, em geral um componente qualquer ou um produto semi-acabado. Segue, desse modo, um fluxo diferente da embalagem de consumo final, e que pode ter as seguintes etapas:

- produção da embalagem;

- envio da embalagem até o fornecedor de componentes;

- acondicionamento do componente e fechamento da embalagem;

- estocagem do produto, já em embalagem de transporte ou não;

- despacho do produto para a empresa de destino;

- recebimento, movimentação, transporte interno e estocagem;

- utilização do componente, com conseqüente esvaziamento da embalagem;

- disposição, reutilização ou reciclagem da embalagem.

Tais embalagens, portanto, são separadas do componente que acondicionam no momento da utilização deste na fabricação do produto final propriamente dito.

Assim, partindo-se das formas de classificação apresentadas no item 3.1.3, e tendo em mente as considerações feitas neste item, tem-se:

Quadro 3 - Embalagem de consumo final x embalagem de uso industrial

\begin{tabular}{|c|c|c|}
\hline Tipo & Embalagem de consumo final & Embalagem de uso industrial \\
\hline O que acondiciona & produto final & componentes diversos \\
\hline $\begin{array}{c}\text { Processo de que } \\
\text { participa }\end{array}$ & comercialização & fabricação \\
\hline Finalidade & $\begin{array}{c}\text { - de consumo } \\
\text { - expositora }\end{array}$ & $\begin{array}{c}\text { - distribuição física } \\
\text { - transporte } \\
\text { - movimentação } \\
\text { - armazenagem }\end{array}$ \\
\hline $\begin{array}{c}\text { Aspectos enfatizados } \\
\text { Função } \\
\text { predominante }\end{array}$ & estéticos & $\begin{array}{c}\text { contenção / proteção } \\
\text { tecnológica }\end{array}$ \\
\hline
\end{tabular}




\subsubsection{A embalagem de uso industrial e o processo produtivo}

Uma vez que a embalagem de uso industrial encontra-se inserida em um determinado processo produtivo, ela estabelece:

- uma relação direta com os componentes e demais elementos necessários à fabricação do produto final: é utilizada para conter, proteger, transportar e armazenar esses componentes;

- uma relação indireta com o produto final desse processo: não o acompanha necessariamente até o consumidor final, mas contribui para sua fabricação.

Assim, torna-se possível integrar o fluxo da embalagem ao fluxo de materiais e processos necessários à fabricação de um produto; faz sentido pensar que a embalagem de uso industrial, ao mesmo tempo em que é um produto e tem seu próprio fluxo, está inserida no fluxo de materiais e processos do produto final, por conter e proteger seus componentes durante certas fases do processo de fabricação. É o que se observa na figura na página seguinte. 


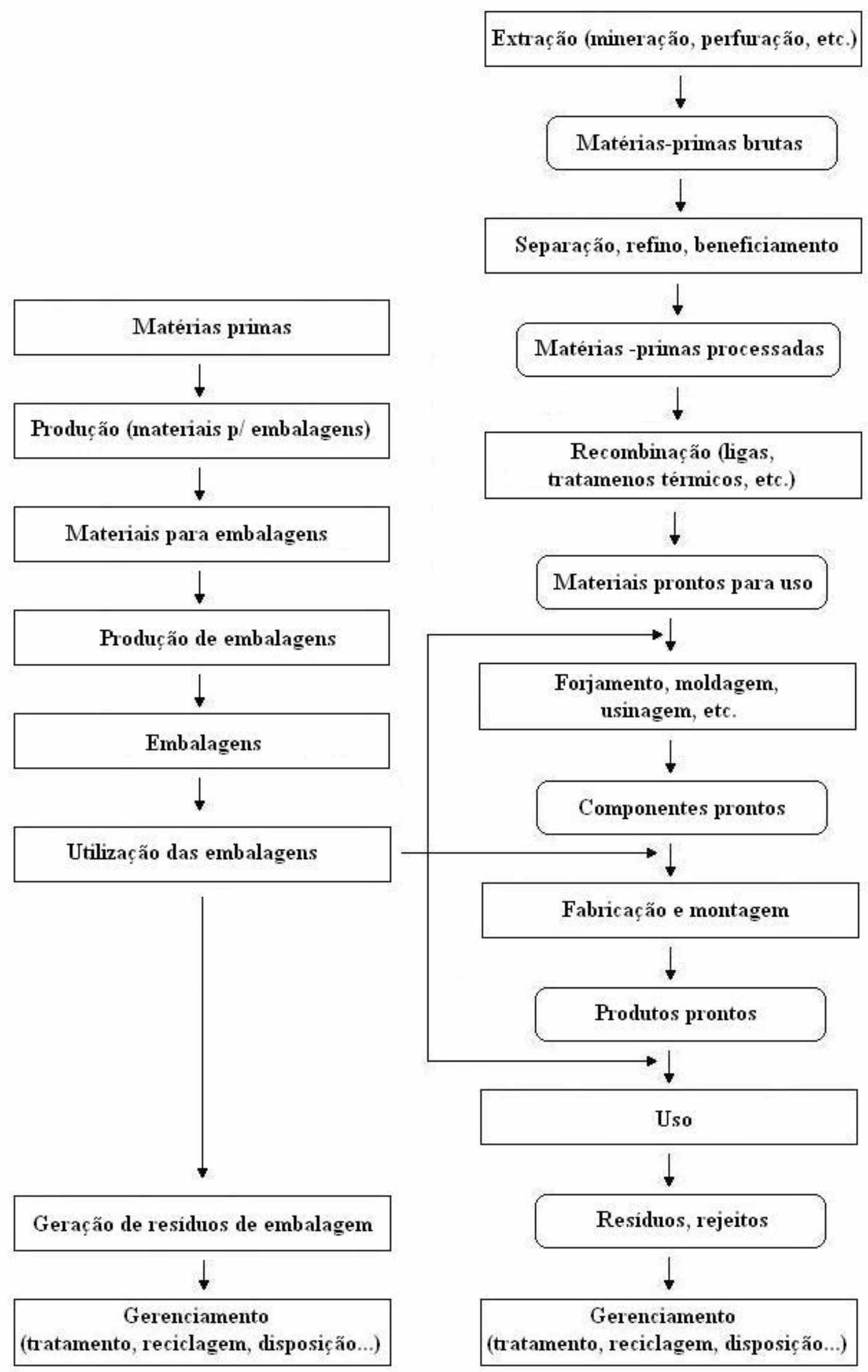

Figura 4 - Fluxos da embalagem e dos materiais e processos (adaptado de JACKSON, 1993) 


\subsection{Embalagem e o meio ambiente}

O aumento do uso de embalagens é um dos efeitos do processo de urbanização e dos modelos de vida decorrentes. O crescimento e adensamento das cidades tornou mais longo e sinuoso o percurso dos recursos, da produção ao consumo, tornando necessárias soluções de acondicionamento que garantissem a conservação dos produtos ao longo de todo o trajeto (SOUSA, 2000).

Os impactos ambientais associáveis às embalagens não cessam após sua fabricação, nem se iniciam quando elas se tornam resíduo. Pelo contrário, ao longo do fluxo de uma embalagem, pode ser detectada a geração de diversos tipos de impacto no meio ambiente, segundo Selke (1994) e Sousa (2000):

- processos de obtenção de materiais para embalagens: contribuem para o esgotamento de recursos naturais. Reservas de materiais como alumínio, ferro e petróleo têm sofrido drásticas diminuições ao longo dos tempos.

- produção de energia para beneficiamento dos materiais e fabricação das embalagens: em certos países, essa energia é produzida com geração de dióxido de carbono, responsável pelo efeito estufa, além de dióxidos de enxofre e óxidos de nitrogênio, ambos associados à chuva ácida.

- fabricação das embalagens: requer consumo de energia e é fonte de geração de resíduos e efluentes, que contribuem para a poluição do ar, água e solo. Um exemplo marcante é a geração de efluentes no processo de branqueamento da polpa de celulose, base para a produção de certos tipos de papel. Diversas modificações neste processo têm contribuído para diminuir a carga poluente gerada. A fabricação de papel, a partir da celulose, também produz efluentes com alta DBO (Demanda Bioquímica de Oxigênio); isto é, os compostos lançados nos corpos d'água consomem grandes quantidades de oxigênio para se decomporem. Outro exemplo é a produção de minério de ferro para fabricação de aço, responsável por emissões de material particulado de vários tipos, contribuindo assim para a poluição do ar e da água.

- transporte das embalagens: resulta em consumo de combustível, muitas vezes de origem fóssil, o que contribui para esgotamento de reservas naturais e, ao mesmo tempo, para a emissão de poluentes e aumento do efeito estufa (SELKE, 1994).

É importante lembrar que as embalagens necessitam de transporte em pelo menos dois momentos: da empresa fabricante das embalagens até a empresa consumidora, que as utiliza para acondicionar seus componentes, e da empresa 
fornecedora de componentes até a empresa que os emprega na fabricação ou montagem de seus produtos.

Por fim, o tratamento e a disposição final dos materiais das embalagens podem apresentar grandes inconvenientes. Alguns deles ao serem queimados, liberam substâncias tóxicas, como é o caso da espuma de poliuretano (MOURA \& BANZATO, 1997). Assim, a solução é a incineração - queima controlada - dos resíduos, ou a simples disposição em aterro. Neste caso, surge a questão: qual o tempo de degradação dos materiais? O papel, se disposto diretamente em aterro, também se degrada muito lentamente; a degradação do plástico é muito lenta, praticamente insignificante. Embalagens de vidro não são degradáveis em aterro (CEMPRE, 2004a; 2004b; 2004c).

O problema da disposição final dos resíduos de embalagens é também apontado por Selke (1994). Além da não-degradação de diversos tipos de materiais, animais podem ter sua vida ameaçada por resíduos de embalagens, ficando presos a eles ou ingerindo-os.

Ainda que em todos esses casos, as atividades relacionadas à embalagem não sejam de forma alguma as únicas causadoras dos impactos mencionados, como lembra a pesquisadora, um estudo criterioso do impacto ambiental causado pelas embalagens ao longo de seu ciclo de vida deve necessariamente considerá-las. Estudos com esta abordagem completa do ciclo de vida de um produto têm recebido o nome de Análise de Ciclo de Vida, e serão discutidos em maiores detalhes no item 3.8.

\subsection{Gerenciamento de resíduos}

O gerenciamento de resíduos de embalagens de uso industrial pode ser inserido no âmbito mais geral do gerenciamento de resíduos originados nos processos produtivos.

Durante boa parte do processo de desenvolvimento industrial, não havia qualquer preocupação com os resíduos e efluentes dos processos produtivos; havia simplesmente a geração e o lançamento no ambiente, sem que processo algum fosse utilizado para a diminuição das quantidades de resíduos geradas ou ao menos de sua periculosidade.

A partir do surgimento dos primeiros conceitos de gerenciamento ambiental, é possível traçar a seguinte linha evolutiva, conforme Oliveira (2002): 
- Os anos 70 caracterizaram-se, de modo geral, pelo chamado princípio do "fim de tubo" (end of pipe): o gerenciamento consistia apenas no tratamento dos resíduos no fim do processo;

- Nos anos 80, passou a ser considerada, adicionalmente, a minimização de danos ambientais, por meio de dispositivos e medidas que visavam o controle do processo;

- o desenvolvimento de conceitos como a prevenção da poluição e produção mais limpa, já nos anos 90, representavam uma nova necessidade, a de revisão dos processos produtivos.

Neste novo século, a estes conceitos somou-se a preocupação em promover uma completa revisão do produto e não apenas do processo de fabricação. Em virtude desta seqüência de acontecimentos, autores como Jackson (1993) afirmam estar ocorrendo uma mudança de paradigma no que diz respeito ao gerenciamento ambiental, refletida nas atitudes de inúmeras instituições governamentais e privadas que já priorizam a prevenção da poluição, considerando a seguinte hierarquia: redução de resíduos e prevenção da poluição, incluindo reciclagem interna; reciclagem externa, reuso e recuperação; tratamento; disposição controlada; disposição não controlada.

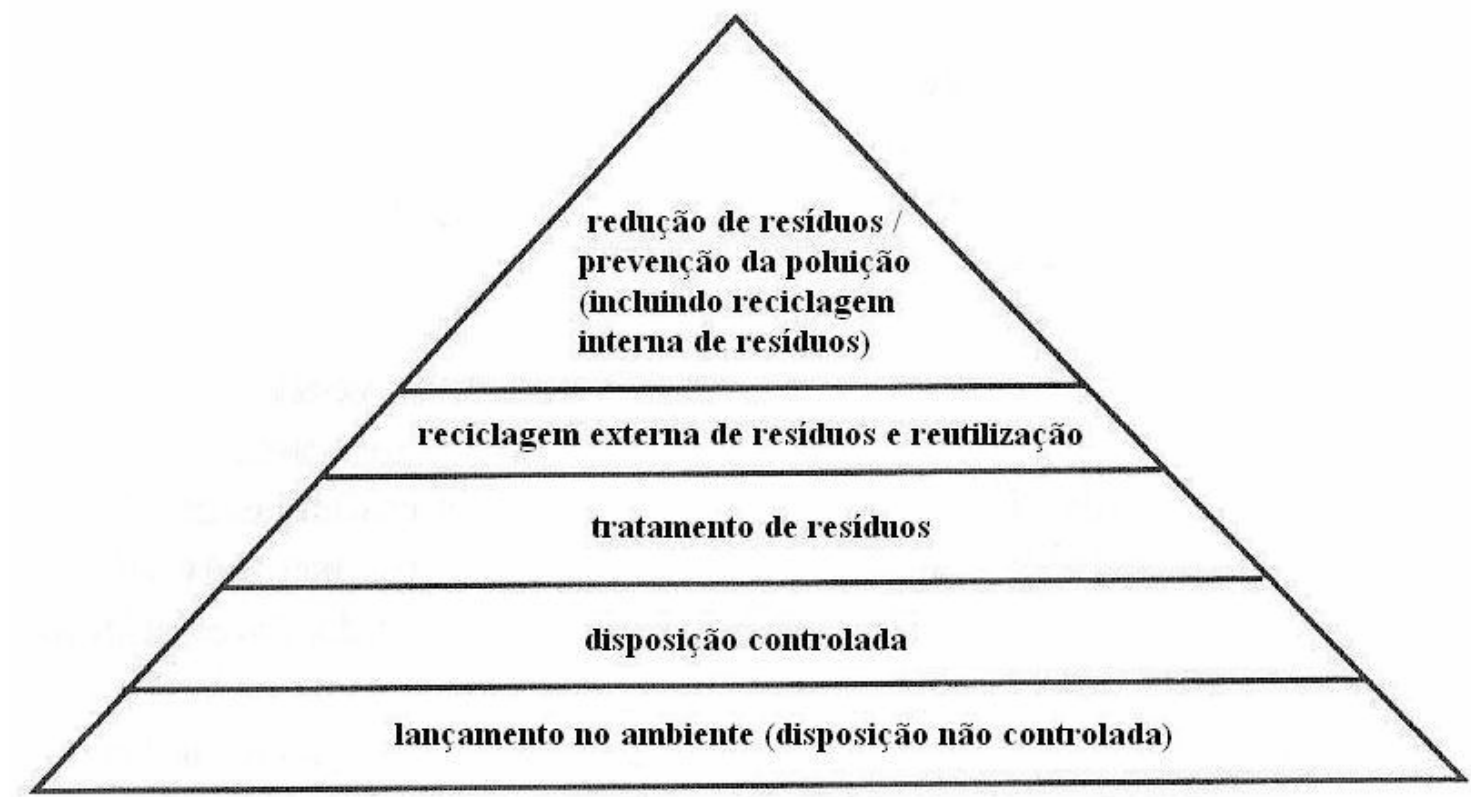

Figura 5 - Hierarquia do gerenciamento de resíduos (adaptada de JACKSON, 1993)

Sobre esta mudança, a Fundação Carlos Alberto Vanzolini (do Departamento de Engenharia de Produção da Escola Politécnica - USP), em seu boletim de março-abril de 2000, lembra que, se ainda há empresários que encaram as questões ambientais como 
restritivas às suas relações comerciais e as pressões públicas como contrárias aos interesses das companhias, os novos produtos e processos de produção, com maior responsabilidade ambiental, constituem parte das novas estratégias competitivas utilizadas por empresas vencedoras para interligar as questões ambientais às decisões de negócios.

\subsubsection{Reciclagem, reutilização, recuperação}

Estes três processos, mencionados anteriormente, têm se popularizado como formas de valorizar os resíduos gerados, isto é, de transformar os resíduos em fonte de energia, materiais ou de recursos.

A reciclagem permite aproveitar sobras de material, e até mesmo resíduos de embalagens, na fabricação de novas embalagens. O Compromisso Empresarial para a Reciclagem (CEMPRE) apresenta em seu site alguns números sobre a reciclagem de certos materiais de embalagens no Brasil e no mundo:

\section{$\underline{\text { Papelão ondulado }}$}

É o material com maior taxa de reciclagem no País. As indústrias fabricantes de caixas de papelão ondulado foram responsáveis pela utilização de 64,5\% das aparas recicladas no Brasil em 2002. Nos EUA a recuperação de embalagens de papelão ondulado em 2002 atingiu 73,9\%, com 23.165 mil toneladas de aparas recuperadas.

\section{$\underline{\text { Vidro }}$}

44\% das embalagens de vidro são recicladas no Brasil, somando 390 mil ton/ano. Desse total, $40 \%$ é oriundo da indústria de envaze, $40 \%$ do mercado difuso, $10 \%$ de bares, restaurantes, hotéis etc, e $10 \%$ do refugo da indústria. Os Estados Unidos produziram 10,3 milhões de toneladas de embalagens de vidro em 2000, sendo o segundo material em massa mais reciclado, perdendo apenas para os jornais. Nos EUA, o índice de reciclagem naquele ano foi de $40 \%$, correspondendo a 2,5 milhões de toneladas. Na Alemanha, o índice de reciclagem em 2001 foi de $87 \%$, correspondendo a 2,6 milhões de toneladas. Índices de reciclagem em outros países: Suíça (92\%), Noruega (88\%), Finlândia (91\%), Bélgica (88\%). 


\section{Plástico rígido/filme}

As resinas plásticas em 2002 foram destinadas para: embalagens (39,73\%), construção civil (13,67\%), descartáveis (11,55\%), componentes técnicos $(8,04 \%)$, agrícola $(7,67 \%)$, utilidades domésticas $(4,72 \%)$, outros $(14,62 \%) .17,5 \%$ dos plásticos rígidos e filme consumidos no Brasil retornam à produção como matéria-prima, o que equivale a cerca de 200 mil toneladas por ano.Deste total, 60\% provêm de resíduos industriais e $40 \%$ do lixo urbano, segundo estimativa da ABREMPLAST (Associação Brasileira de Recicladores de Materiais Plásticos).

Atualmente, a reutilização é válida para certos tipos de embalagens, que são usados e reutilizados diversas vezes com um mesmo produto, por uma mesma indústria, dependendo dos custos de retorno, das condições de distribuição física e comercial, segundo Moura \& Banzato (1997). Tambores, caixas plásticas, caixas de madeira, sacaria têxtil, botijões de gás e, mais raramente, caixas de papelão são, em maior ou menor grau, reutilizáveis. A redestinação, tanto da embalagem como de seus materiais, é também possível: a indústria pode recorrer às suas próprias embalagens usadas para alguma nova aplicação; embalagens como tambores, bombonas, paletes e caixas de madeira podem ser recuperadas por terceiros. Outra forma de redestinação é a que emprega o material da embalagem: latas são matéria-prima para pequenas indústrias artesanais, enquanto que a madeira pode ser empregada em habitações, móveis e brinquedos, além de servir como combustível.

Outra alternativa explorável é a recuperação de materiais a partir das próprias embalagens, o que diminui a necessidade de obtê-los através da exploração de reservas naturais; um exemplo é a possibilidade de se recuperar o estanho das latas metálicas (MOURA \& BANZATO, 1997). Segundo Rhyner et al. (1995), a prática de recuperação de materiais é efetiva em casos como o do aço.

$\mathrm{O}$ reaproveitamento de materiais e a reutilização de embalagens esbarram, porém, em certos obstáculos. A reciclagem, por exemplo, é dificultada no caso de contaminação do material: o papelão pode estar contaminado com graxa, o vidro pode conter terra e pedaços de cristal, e assim por diante. A combinação de materiais em embalagens compostas dificulta a separação destes; assim, a reciclagem deste tipo de embalagem é conseqüentemente dificultada, ainda que ela seja composta por materiais que são individualmente recicláveis. 
Outro exemplo é a reciclagem de vidro: segundo o CEMPRE (2004c), devido ao peso do material, uma das dificuldades para sua reciclagem é o custo do transporte da sucata. Os sucateiros e vidrarias costumam exigir o mínimo de 10 toneladas para fazer a coleta a uma distância não superior a 400 quilômetros.

\subsection{Prevenção da poluição (P2): o conceito de redução na fonte}

A prevenção da poluição no setor industrial não é um conceito novo: as operações industriais tradicionalmente adotam uma série de técnicas de redução de resíduos para reduzir custos de produção e aumentar lucros, afirma Shen (1995). O pesquisador, no entanto, lembra que em 1976, Joseph Ling, da 3M, apresentou um programa chamado "Prevenção da poluição Compensa", ou 3P (de Pollution Prevention Pays), durante um seminário da Comissão Econômica Européia das Nações Unidas sobre princípios e criação de tecnologias não-geradoras de resíduo, ocorrido em Paris.

Segundo Susag (1982), o objetivo do programa consiste em prevenir ou minimizar a potencial poluição em sua fonte, de forma que o tratamento no fim do processo de manufatura não seja necessário, e, depois que o produto deixa a fábrica, não haja maiores problemas no uso ou disposição final. Royston (1982) ressalta que os avanços tecnológicos e administrativos, obtidos com baixos investimentos em modificações na planta e no processo e nenhum investimento em equipamentos adicionais de controle da poluição, a 3M deixou de gerar, em suas plantas no mundo todo, centenas de milhares de toneladas de efluentes gasosos, milhões de toneladas de resíduos sólidos e centenas de milhões de litros de águas residuárias; e, ao invés de gastar dinheiro para obter este resultado, a companhia economizou mais de US\$ 80 milhões entre 1976 e 1982. Os custos de produção tornaram-se desse modo mais baixos que antes, quando eram empregadas práticas mais poluentes.

$\mathrm{O}$ autor menciona ainda um estudo de 17 companhias que administravam 120 plantas de papel e celulose nos EUA, que mostrou uma forte correlação entre melhor controle da poluição e maior lucro; os pesquisadores concluíram que o maior lucro refletia os menores custos associados ao melhor controle da poluição e gerenciamento mais eficiente; em outras palavras, ao mesmo tempo em que trouxe benefícios através da diminuição no desperdício de recursos, a prevenção da poluição também resultou em menor impacto ambiental. 
No programa da 3M e nos que se seguiram, a prevenção da poluição sempre está associada à redução na fonte. No entanto, de acordo com Thomas (1995), ao longo dos anos 80, a terminologia de redução de resíduos favoreceu o termo minimização de resíduos. Claramente, esta terminologia, que não abrangia medidas de redução na fonte, não atingiu o objetivo desejado. Muitas empresas relutavam em implementar projetos de redução na fonte, preferindo concentrar seus esforços no aumento da eficiência dos tratamentos de "fim de tubo", o que resultou em falta de progresso em direção à real redução na geração de resíduos.

A terminologia prevenção da poluição, segundo a autora, identifica a estratégia desejada e é um objetivo "superior". Em termos simples, a prevenção da poluição visa à redução real da quantidade de emissões tóxicas ano ambiente. Difere da minimização de resíduos porque, em primeiro lugar, não gera resíduos; ao contrário, previne a geração de resíduos que devem ser tratados, estocados, dispostos, ou em último caso destruídos.

Segundo Shen (1995), a redução na fonte abrange qualquer prática que:

a) reduza a quantidade de quaisquer substâncias que entram em um fluxo de resíduos ou são lançadas no ambiente sem passarem por reciclagem ou tratamento;

b) reduza os riscos à saúde pública e ao ambiente associados ao lançamento de tais substâncias; isto é, que reduza a toxicidade dos resíduos;

c) enseje modificações em equipamentos, tecnologia, processos, procedimentos, reformulação ou reprojeto de produtos, substituição de matérias primas e melhoramentos na manutenção, treinamento e controle.

Além disso, para a aplicação de técnicas de prevenção da poluição, a definição de resíduo deve se estender além do foco de resíduos perigosos para incluir todos os materiais gasosos, aquosos, sólidos e semi-sólidos que acabarão, cedo ou tarde, sendo dispostos no ambiente por sua aparente falta de valor. A definição de toxicidade deve incluir elementos tóxicos ao ar, à água e resíduos perigosos e diversos (THOMAS, 1995)

Para Jackson (1993), a implantação de medidas visando à prevenção da poluição deve considerar os seguintes fatores, em ordem decrescente de importância: atividades, produtos, materiais e processos.

Atividades: aumento na produção de componentes substituíveis; fabricação de produtos e embalagens reutilizáveis pelos consumidores; mudança para atividades menos poluidoras.

Produtos: mudança na composição, aumento na durabilidade. 
Materiais: redução no consumo de material - por exemplo, na quantidade de embalagem utilizada; utilização de materiais menos tóxicos e materiais reciclados; reutilização de sobras de material. A substituição de materiais e produtos, enfatiza SHEN (1995), é questão complexa, pois deve considerar as preferências dos consumidores internos e externos, além dos aspectos econômicos e tecnológicos.

Processos: melhora nas operações; condução de auditorias ambientais; implantação de planos regulares de manutenção preventiva e de programas de treinamento de empregados; reciclagem no processo, que permite reutilizar materiais em excesso ou desnecessários em estágios subseqüentes da produção, e que assim se tornaram resíduos; adoção de tecnologia mais avançada, que permita controle sobre as variáveis envolvidas e até mesmo a automação do processo; modificação de processos de limpeza; técnicas de separação de materiais, que reduzem a quantidade final a ser gerenciada; aperfeiçoamento nas atividades de setores como oficinas, laboratórios, escritórios e refeitórios.

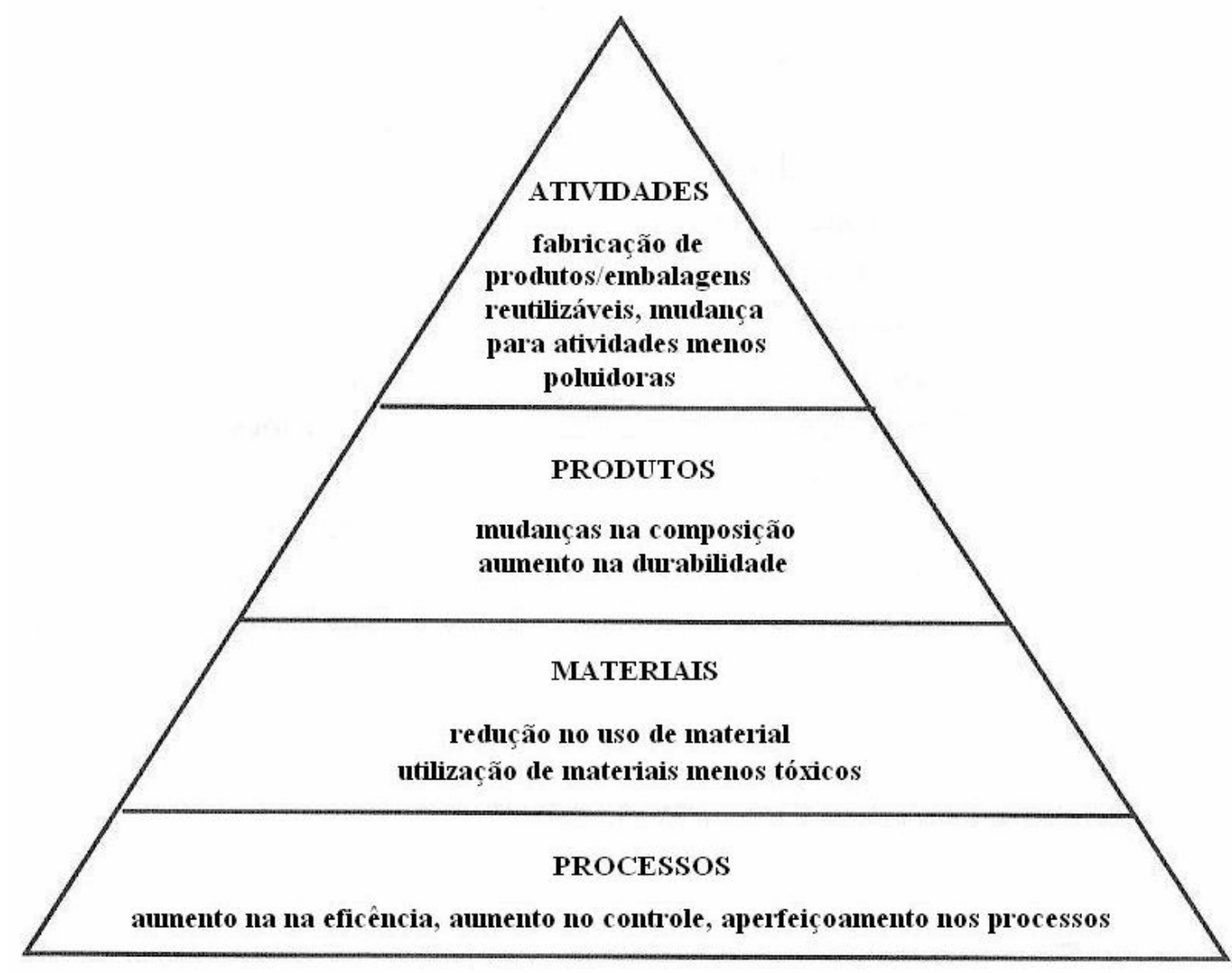

Figura 6 - Hierarquia de opções "preventivas" (adaptada de JACKSON, 1993) 
O autor, por fim, observa que o progresso técnico em direção à prevenção da poluição ocorre de forma descentralizada, uma vez que é conduzido por considerações sobretudo econômicas, além de ser freqüentemente específico a um dos muitos processos industriais existentes. Isto porque os estudos para identificação de oportunidades e implantação de medidas de prevenção da poluição em um determinado processo devem considerar as peculiaridades do processo em questão, para serem realmente efetivos.

\subsubsection{Benefícios da prevenção da poluição}

A CETESB (2003) aponta uma série de benefícios, de ordem ambiental, social e econômica, que podem ser conseguidos através de um programa de P2:

- econômicos: economia de água, materiais e energia; redução de gastos relativos ao gerenciamento dos resíduos; aumento na qualidade do produto e na competitividade da empresa;

- sociais: aumento da segurança no ambiente de trabalho; redução de afastamentos por acidentes; aumento na motivação dos funcionários; melhoria da imagem pública da empresa pela redução de possíveis conflitos com a comunidade circunvizinha;

- ambientais: redução do uso de matérias-primas tóxicas; redução da geração de resíduos; minimização da transferência de poluentes de um meio para o outro; melhoria do desempenho ambiental; redução e eliminação de conflitos com órgãos de fiscalização.

É interessante, neste ponto, recorrer novamente a Susag (1982). Ele lembra que muitas pessoas erroneamente acreditam que a simples combinação de prevenção da poluição, tratamento e medidas de reciclagem ou reuso eliminará a geração de resíduos industriais e a necessidade de instalações para disposição final. $\mathrm{O}$ fato é que tratamentos de resíduos e processos de reciclagem geram necessariamente resíduos, por vezes perigosos, que precisam ser dispostos em algum lugar; dessa forma, instalações para disposição de resíduos no solo serão sempre necessários. Mesmo avançadas instalações para incineração com 99,9\% de eficiência produzem resíduos: após a fração metálica ter sido removida por processo eletromagnético, restam as cinzas que, dependendo do caso, podem conter materiais como cromo e chumbo e, desse modo, devem ser dispostas em aterros especiais para resíduos perigosos. 
O autor acredita que o governo, a indústria e a comunidade devem cooperar para se chegar a um método aceitável para disposição dos resíduos que sem dúvida restarão, mesmo após medidas de prevenção, reciclagem, reutilização e tratamento.

\subsubsection{Barreiras à prevenção da poluição}

Thomas (1995) descreve as possíveis barreiras a serem encontradas na tentativa de se estabelecer um programa de prevenção da poluição, adiantando que nenhuma delas tem se mostrado insuperável. Os entraves, segundo ela, podem ser de ordem econômica, técnica e regulatória.

\section{Barreiras econômicas}

A vantagem econômica é, sem dúvida, o parâmetro que determina a continuidade de qualquer projeto em uma empresa; assim, problemas de ordem econômica são freqüentemente fatores-chave para a interrupção desses projetos. Entre as potenciais barreiras econômicas à prevenção da poluição estão:

- aumentos nos custos de operação em razão de novos equipamentos para reuso e reciclagem;

- falta de capital para dar continuidade a projetos, ou transferência de capital para outros projetos não orientados à produção;

- conclusão de que os benefícios econômicos serão muito pequenos.

\section{$\underline{\text { Barreiras técnicas }}$}

Motivos de ordem técnica são em geral as reais barreiras a programas de P2; podem ser citados como exemplos:

- falta de capacidade técnica na empresa para efetuar as mudanças e implementar novas tecnologias

- mudanças freqüentes na produção, como por exemplo, sistemas produtivos que operam em lote (batelada), com mudanças constantes na linha;

- limitações físicas na empresa, como limitações de espaço para eventuais equipamentos adicionais, ou instalações insuficientes de energia elétrica e água;

- barreiras comportamentais, como recusa à mudança por parte do pessoal, refletida na falta de vontade de adotar novos procedimentos e tecnologias;

- preocupações técnicas sobre a qualidade do produto; e

- barreiras institucionais resultantes de falta de comprometimento da gerência. 


\section{$\underline{\text { Barreiras regulatórias }}$}

Pode-se verificar o surgimento de entraves legais a partir da diferença na forma com que as leis ambientais considerem as indústrias, se estas forem grandes e pequenas, ou federais ou privadas. Outras barreiras dessa natureza podem ser:

- custo e tempo envolvidos na obtenção ou revisão de licenças;

- limitações impostas ao transporte de resíduos, que impeçam ou dificultem sua transferência para locais onde se poderia realizar procedimentos de recuperação ou reciclagem.

\subsubsection{Programa de prevenção da poluição}

A CETESB (2003) sugere a seguinte metodologia para a implementação de ações de produção mais limpa / prevenção da poluição:

1) comprometimento da direção da empresa;

2) definição da equipe de P2;

3) elaboração da Declaração de Intenções;

4) estabelecimento de prioridades, objetivos e metas;

5) elaboração de cronograma de atividades;

6) disseminação de informações sobre P2;

7) levantamento de dados;

8) definição de indicadores de desempenho;

9) identificação de oportunidades de P2;

10) levantamento de tecnologias;

11) avaliação econômica;

12) seleção das oportunidades de $P 2$;

13) implementação das medidas de P2;

14) avaliação dos resultados;

15) manutenção do programa.

As etapas 7 a 12 podem ser realizadas durante uma auditoria ambiental.

\subsubsection{Auditoria ambiental - identificação de oportunidades de P2}

Segundo La Rovere (coord.) et al. (2003), auditoria é uma avaliação independente, relacionada a um determinado assunto, realizada por especialista que usa seu julgamento profissional e comunica o resultado ao cliente. A auditoria ambiental, por sua vez, é um instrumento que permite que as empresas atendam a práticas, 
políticas, procedimentos ou requisitos estipulados com o objetivo de evitar a degradação ambiental. SHEN (1995) afirma que a auditoria ambiental permite identificar e corrigir problemas associados à operação da fábrica, o que além de adequá-la a empresa a novas normas e padrões, pode gerar economia pela minimização na geração de resíduos, e melhorar a imagem da companhia junto à comunidade e governo; pode ser conduzida em muitos ambientes diferentes por indivíduos com diversas formações e habilidades. Segundo Schilling et al. (2000), a redução de resíduos e a prevenção da poluição devem ser os principais objetos de identificação durante a auditoria para que posteriormente o planejamento do gerenciamento dos resíduos industriais satisfaça o evitar, o reduzir, o reutilizar e o reciclar.

Uma auditoria pode ser desenvolvida em 3 fases:

- Pré-avaliação e preparação da auditoria: definição da equipe envolvida, divulgação do objetivo junto aos funcionários, estabelecimento de metas, e das áreas a serem cobertas pela auditoria.

- Coleta de dados (inspeção de resíduos): verificação visual, verificação de amostragem e classificação, balanço de massa ou verificação de entradas/saídas. Podem ser empregadas tabelas que descrevam os resíduos gerados em cada operação, as opções de prevenção da poluição e que também estabeleçam critérios para a definição de quais resíduos devem ter prioridade de tratamento, de acordo com as possibilidades de gerenciamento: não geração, redução da geração, reciclagem do resíduo gerado, tratamento e disposição final.

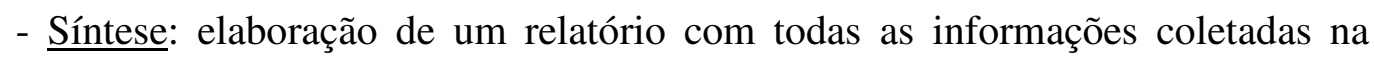
auditoria. Pode ser composto de um resumo introdutório, seguido de detalhamento, com informações sobre o escopo, participantes da auditoria, setores avaliados, entrevistas, definições de padrões e normas a serem seguidas, resultados, propostas e observações sobre boas práticas existentes na empresa (adaptado de SHEN, 1995).

A equipe interna de prevenção da poluição, formada por representantes de setores como gerência, pesquisa e desenvolvimento, marketing e chão de fábrica, seria responsável pelas etapas seguintes, isto é, pela análise do resultado da auditoria, implementação das medidas de $\mathrm{P} 2$, reavaliando processos ou reprojetando o processo e o produto, e a manutenção do programa, avaliando periodicamente seu progresso. As ações deste grupo serão pautadas por metas e cronogramas previamente determinados. 


\subsection{Produção mais limpa}

Cunhado em 1989 por um grupo de trabalho do PNUMA (Escritório da Indústria e Meio Ambiente do Programa das Nações Unidas para o Meio Ambiente), o termo "produção mais limpa" descreve a aplicação contínua de uma estratégia ambiental preventiva integrada aos processos, produtos e serviços, para aumentar a eco-eficiência e evitar ou reduzir os danos ao homem e ao ambiente ${ }^{2}$ :

- nos processos produtivos: pela conservação de matérias primas e energia, eliminação de matérias tóxicas e redução da quantidade e toxicidade dos resíduos e emissões;

- nos produtos: por meio da redução dos impactos negativos ao longo do ciclo de vida de um produto, desde a extração das matérias-primas até sua disposição final;

- nos serviços: através da incorporação de preocupações ambientais no planejamento e entrega dos serviços (GASI, 2002).

O próprio uso da palavra "produção" pode sugerir que o conceito abranja apenas os processos industriais, porém, segundo Jackson (1993), está claro que os produtos devem ser tratados com a mesma atenção. E mais: são necessárias estratégias que considerem não apenas os processos de fabricação e os produtos destes processos, mas também as formas com que as escolhas de material são feitas e a dinâmica do sistema de produção e consumo ao longo do qual essas escolhas são implementadas.

O pesquisador prossegue afirmando que a aplicação do conceito de produção mais limpa deve se estender não apenas às práticas industriais, mas às políticas econômicas e aos processos de escolha dos consumidores, sejam eles dentro ou fora da indústria, de modo a garantir que os processos produtivos, ciclos de produto e padrões de consumo permitam o desenvolvimento e o atendimento a necessidades básicas, sem a degradação ou destruição dos ecossistemas nos quais esse desenvolvimento deve ocorrer: é, em suma, o mesmo objetivo do desenvolvimento sustentável.

Segundo o CNTL - Centro Nacional de Tecnologias Limpas (2003), podem ser utilizadas várias estratégias para a introdução de técnicas de Produção mais Limpa em um processo produtivo, tendo em vista metas ambientais, econômicas e tecnológicas. A priorização destas metas é definida em cada empresa, através de seus profissionais, e

\footnotetext{
${ }^{2}$ Inicialmente, havia sido adotada a expressão 'produção limpa' (clean production); o grupo do PNUMA a substituiu por 'produção mais limpa', por reconhecer que todos os processos têm um certo impacto e, ao mesmo tempo, para indicar um processo que deve evoluir continuamente.
} 
baseada em sua política gerencial: dependendo do caso, os fatores econômicos podem ser os determinantes na avaliação e revisão de um processo produtivo, e a minimização de impactos ambientais, uma simples consequiência; alternativamente, os fatores ambientais poderão ser prioritários. Sobre esta abordagem econômica do conceito, Oliveira (2002) afirma que o conceito de produção mais limpa é uma forma de considerar todas as saídas do processo, especialmente as indesejáveis, como custo adicional e que, portanto, devem ser otimizadas.

\subsubsection{Prevenção da poluição e produção mais limpa}

Estas duas expressões, citadas freqüentemente em meio à "selva" de termos criados ao longo das últimas décadas para definir os novos conceitos de gerenciamento ambiental, são muitas vezes empregadas com o mesmo sentido, de evitar a geração de resíduos nos processos. Há, porém, um modo de vê-las como termos diferentes e complementares.

Jackson (1993) considera que a produção mais limpa é "uma abordagem operacional do desenvolvimento do sistema de produção e consumo", que incorpora a noção de prevenção, ou, ainda, o desenvolvimento de "uma abordagem operacional do paradigma da prevenção".

Em outras palavras, adotar o conceito de produção mais limpa significa colocar em prática um conjunto de medidas, aplicáveis à produção e ao consumo, que tenham a prevenção da poluição como objetivo principal. Assim, pode-se considerar a prevenção da poluição como parte integrante do conceito de produção mais limpa.

\subsection{A prevenção da poluição e a série de normas ISO 14000}

A gestão ambiental abrange uma vasta gama de questões, inclusive aquelas com implicações estratégicas e competitivas. As Normas Internacionais de gestão ambiental, como as da série ISO 14000, têm por objetivo definir os elementos de um sistema de gestão ambiental (SGA) eficaz, passível de integração com outros requisitos de gestão, de forma a auxiliá-las a alcançar seus objetivos ambientais e econômicos (ABNT, 1996). Moura (2004) identifica, como conseqüência dos procedimentos gerenciais guiados por normas, um estreitamento na comunicação entre clientes e fornecedores, sobretudo quando as relações comerciais envolvem o comércio internacional 
Primeira das normas da série, a ISO 14001 foi editada originalmente em 1996, e atualizada no final de 2004, recebendo sempre versões em português editadas pela ABNT (Associação Brasileira de Normas Técnicas). A norma fixa as especificações para a certificação e avaliação do SGA de uma organização. Essa norma foi fortemente inspirada na norma inglesa BS 7750 - Specification for Environmental Management Systems, ou Especificação para Sistemas de Gerenciamento Ambiental, editada em caráter oficial em 1994, e cancelada quando do lançamento da ISO 14.001 (MOURA, 2004).

O objetivo da ISO 14001 é, segundo seu próprio texto, "equilibrar a proteção ambiental e a prevenção de poluição com as necessidades sócio-econômicas". O texto da norma define prevenção da poluição como sendo "o uso de processos, práticas, materiais ou produtos que evitem, reduzam ou controlem a poluição, os quais podem incluir reciclagem, tratamento, mudanças no processo, mecanismos de controle, uso eficiente de recursos e substituição de materiais", e apresenta como benefícios potenciais a redução de impactos ambientais adversos e a melhoria da eficiência e a redução de custos.

O texto da ISO 14001 esclarece que a norma engloba apenas requisitos que podem ser auditados para fins de certificação; o único requisito de desempenho ambiental estipulado na norma é o comprometimento com à legislação e regulamentos aplicáveis e com a melhoria contínua. Em outras palavras, a ISO 14001 se aplica apenas aos aspectos ambientais que possam ser controlados e influenciados pela organização, não estabelece critérios específicos de desempenho ambiental. Quanto a esse aspecto, pode-se mencionar a NBR ISO 14004, também editada em 1996, que trata das diretrizes gerais sobre princípios, sistemas e técnicas de apoio. Esta norma apresenta exemplos e tópicos de ajuda prática no estabelecimento de objetivos, metas, critérios e indicadores de desempenho.

O Sistema de Gestão Ambiental é definido pela ISO 14001 como "a parte do sistema de gestão global que inclui estrutura organizacional, atividades de planejamento, responsabilidades, práticas, procedimentos, processos e recursos para desenvolver, implementar, atingir, analisar criticamente e manter a política ambiental". Considera que o sistema de gestão ambiental é uma ferramenta que permite à organização atingir e controlar, de forma sistemática, o nível de desempenho ambiental por ela mesma estabelecido. A norma identifica cinco etapas no estabelecimento e manutenção de um SGA, a saber: 
1) Comprometimento e definição da política ambiental;

2) Planejamento;

3) Implementação e operação;

4) Medição, avaliação e ações corretivas;

5) Análise crítica.

Cada etapa precisa atender a requisitos básicos, descritos no texto da norma.

Para Moura (2004), a implantação de um SGA envolve três conjuntos básicos de atividades:

- Análise da situação atual da empresa: verificar "onde se está”, no tocante ao desempenho, aos produtos, serviços prestados e sistemas de produção, e ao atendimento aos requisitos da legislação. É a fase de diagnóstico do problema, levantando-se os impactos ambientais principais que resultam das atividades da empresa.

- Estabelecimento de metas: estudar as possibilidades físicas, recursos materiais e humanos necessários e, a partir de diretrizes da Política Ambiental, definir "onde se quer chegar", em termos de melhorias, em um certo período de tempo.

- Estabelecimento de métodos: estabelecer um modo de trabalho, para que se saiba "como chegar" aos resultados pretendidos, para que sejam atingidas as metas.

Esse processo, dito 'dinâmico e cíclico', de planejar, implementar, verificar e analisar criticamente, permite à organização interessada, entre outras possibilidades:

"b) identificar os aspectos ambientais decorrentes de atividades, produtos ou serviços da organização, passados, existentes ou planejados, para determinar os impactos ambientais significativos;

c) identificar requisitos legais e regulamentares aplicáveis;

d) identificar prioridades, estabelecendo objetivos e metas ambientais apropriados (...)" (ABNT, 1996a)

Além disso, à medida que o SGA da organização torna-se "maduro", estabelecido, é esperado que a organização passe a executar com mais facilidade este ciclo de atividades.

\section{$\underline{\text { Política ambiental }}$}

É a “declaração da organização, expondo suas intenções e princípios em relação ao seu desempenho ambiental global, que provê uma estrutura para ação e definição de seus objetivos e metas ambientais." (ABNT, 1996a). Além da observância dos 
regulamentos ambientais, a ISO 14004 indica que a política pode declarar comprometimentos com:

- minimização de impactos ambientais negativos de novos desenvolvimentos;

- desenvolvimento de procedimentos para avaliação de desempenho ambiental;

- incorporação da abordagem de ciclo de vida ${ }^{3}$;

- concepção de produtos de modo a minimizar seus impactos ambientais nas fases de produção, uso e disposição;

- prevenção da poluição, redução de resíduos e do consumo de recursos e, quando viável, comprometimento com a recuperação e reciclagem em substituição à disposição;

- encorajamento do uso de SGA por fornecedores e prestadores de serviços.

A organização pode focalizar inicialmente seus esforços em setores onde há benefícios mais óbvios e imediatos, como o cumprimento de leis e regulamentos, ou a utilização mais eficiente de materiais. A intenção é que, com o passar do tempo e o conseqüente amadurecimento do SGA, sejam buscadas melhorias em diversos outros setores, de forma que as considerações ambientais acabem sendo integradas em todas as decisões de negócios (ABNT, 1996b).

\section{$\underline{\text { Planejamento }}$}

Os elementos do sistema de gestão ambiental relativos ao planejamento incluem, segundo a ISO 14004:

- identificação de aspectos ambientais e avaliação dos impactos ambientais $\operatorname{associados}^{4}$;

- requisitos legais;

- política ambiental;

- critérios internos de desempenho;

- objetivos e metas ambientais;

- planos ambientais e programa de gestão.

\footnotetext{
${ }^{3}$ Mais sobre o conceito de "ciclo de vida" no item 3.8.

4 Aspecto ambiental: elemento qualquer da atividade, produto ou serviço da organização que pode ter impacto benéfico ou adverso sobre o ambiente. Ex.: envolver descargas, emissões, ruídos, consumo ou reutilização de um material. Impacto ambiental: alteração no meio ambiente resultante do aspecto. Ex.: a poluição ou contaminação da água ou esgotamento de um recurso natural. (ABNT, 1996b)
} 
A identificação dos aspectos ambientais é um processo contínuo que determina o impacto - positivo ou negativo - passado, presente e potencial das atividades da organização sobre o meio ambiente. Pode ser realizada nas seguintes etapas:

1) Seleção de uma atividade, produto ou serviço;

2) Identificação do maior número possível de aspectos ambientais da atividade, produto ou serviço, como por exemplo, emissões atmosféricas, lançamentos em corpos de água, gerenciamento de resíduos, uso de matérias-primas e recursos naturais, entre outros;

3) Identificação do maior número possível de impactos ambientais, reais ou potenciais, positivos ou negativos, associados a cada aspecto identificado.

Exemplos dessas três etapas são mostrados a seguir.

Quadro 4 - identificação de aspectos e impactos

\begin{tabular}{|l|l|l|}
\hline \multicolumn{1}{|c|}{$\begin{array}{c}\text { Atividade, produto ou } \\
\text { serviço }\end{array}$} & \multicolumn{1}{|c|}{ Aspecto } & \multicolumn{1}{c|}{ Impacto } \\
\hline $\begin{array}{l}\text { Atividade - Manuseio de } \\
\text { materiais perigosos }\end{array}$ & $\begin{array}{l}\text { Possibilidade de derrame } \\
\text { acidental }\end{array}$ & $\begin{array}{l}\text { Contaminação do solo ou da } \\
\text { água }\end{array}$ \\
\hline Produto - Refino do produto & $\begin{array}{l}\text { Reformulação do produto } \\
\text { para reduzir seu volume }\end{array}$ & $\begin{array}{l}\text { Conservação de recursos } \\
\text { naturais }\end{array}$ \\
\hline $\begin{array}{l}\text { Serviço - Manutenção de } \\
\text { veículos }\end{array}$ & Emissões de escapamento & $\begin{array}{l}\text { Redução de emissões para a } \\
\text { atmosfera }\end{array}$ \\
\hline
\end{tabular}

Fonte: ABNT (1996b)

4) Avaliação da importância dos impactos: pode levar em conta considerações ambientais, como a escala, severidade e duração do impacto, e considerações comerciais, como o custo para alteração do impacto, efeito de uma alteração sobre outras atividades e processos, preocupações das partes interessadas e efeitos na imagem pública da organização.

Com base nos impactos identificados, a organização deve estabelecer seus objetivos e metas ambientais. Objetivos são os propósitos globais para o desempenho ambiental, identificados na política ambiental; podem incluir, segundo a ISO 14004:

- redução no consumo de recursos;

- redução na geração de resíduos;

- redução ou eliminação da liberação de poluentes no meio ambiente; 
- projeto de produtos de modo a minimizar seus impactos ambientais nas fases de produção, uso e disposição;

- controle do impacto ambiental das fontes de matérias-primas;

- minimização de impactos ambientais negativos de novos empreendimentos.

Metas ambientais são os requisitos de desempenho detalhado, resultantes dos objetivos ambientais, e que precisam ser estabelecidos e atendidos para que tais objetivos sejam atingidos, tudo dentro de prazos especificados.

A norma ISO 14001 determina expressamente que os objetivos e metas estabelecidos devem ser compatíveis com a política ambiental, incluindo o comprometimento com a prevenção de poluição.

Na determinação de seus objetivos e metas, uma organização deve definir seus próprios critérios internos de desempenho. Segundo a ISO 14004, uma organização pode possuir critérios relativos a áreas como:

- sistemas de gestão;

- fornecedores e prestadores de serviços;

- gestão de produtos;

- prevenção de poluição e conservação de recursos;

- modificação de processos;

- gerenciamento de resíduos;

- gerenciamento da água (por exemplo, águas servidas, pluviais e subterrâneas);

- gerenciamento da qualidade do ar;

- transporte.

Ainda segundo a mesma norma, uma vez definidos os objetivos e metas, o progresso em direção a um objetivo pode ser medido por meio de indicadores de desempenho ambiental, tais como:

- quantidade de matérias-primas ou energia utilizada;

- quantidade de emissões, tais como CO2;

- produção de resíduos por quantidade de produto acabado;

- eficiência no uso de materiais e energia;

- porcentagem de resíduos reciclados;

- porcentagem de material reciclado usado na embalagem;

- número de quilômetros rodados pelos veículos por unidade de produção;

- quantidade de poluentes específicos, como $\mathrm{NOx}, \mathrm{SO} 2, \mathrm{CO}, \mathrm{HC}, \mathrm{Pb}, \mathrm{CFC}$;

- investimentos em proteção ambiental; 
- número de ações judiciais;

- área de terreno destinada a reserva natural.

A ISO 14004 apresenta o seguinte exemplo integrado "objetivo-metaindicador":

\section{Objetivo}

- reduzir a energia requerida para operações industriais

$\underline{\text { Meta }}$

- atingir redução de $10 \%$ no consumo de energia em relação ao ano anterior

$\underline{\text { Indicador }}$

- quantidade de combustíveis e energia elétrica por unidade de produção

Assim, com relação às embalagens envolvidas na produção, pode-se ter:

\section{$\underline{\text { Objetivo }}$}

- reduzir a geração de resíduos de embalagem no processo de fabricação

$\underline{\text { Meta }}$

- atingir redução de $20 \%$ na geração de tais resíduos em relação ao ano anterior

Indicador

- quantidade de resíduos de embalagem gerados por unidade de produção

A organização pode atingir os objetivos e metas definidos previamente através de um programa de gestão ambiental, que deve incluir considerações sobre planejamento, projeto, produção, comercialização, uso e disposição final - tanto para as atividades, produtos ou serviços atuais quanto para os futuros - e a atribuição de responsabilidades ambientais em cada função e nível pertinente da organização. Tais responsabilidades não devem se restringir à área ambiental, mas sim incluir outras áreas da organização, como a gerência operacional ou outras funções não especificamente ambientais (ABNT, 1996a).

\section{Implementação e operação}

Na implementação do SGA, é necessário definir e disponibilizar os recursos humanos, físicos e financeiros necessários ao atingimento dos objetivos ambientais. 
Podem ser desenvolvidos procedimentos para acompanhar os benefícios e os custos de suas atividades, produtos ou serviços, tais como o custo do controle de poluição, resíduos e disposição.

É preciso também estabelecer e manter procedimentos de controle sobre operações e atividades que contribuem para os impactos ambientais significativos, tais como: pesquisa e desenvolvimento, projeto e engenharia; compras, prestadores de serviços, processos de produção e manutenção e transporte (ABNT, 1996b).

A ISO 14004 divide as atividades de controle em três categorias:

- atividades destinadas a prevenir a poluição e conservar recursos em novos projetos prioritários, modificações de processos e gestão de recursos, propriedade (aquisições, alienação de ativos e gestão patrimonial) e novos produtos e embalagens;

- atividades de gestão diária para assegurar conformidade com os requisitos internos e externos da organização e garantir sua eficiência e eficácia;

- atividades de gestão estratégica destinadas a antecipar e atender a novos requisitos ambientais.

\section{Verificação e ação corretiva}

Esta etapa compreende atividades como:

- Monitoramento e medição periódica das características principais das operações e atividades que possam ter um impacto significativo sobre o meio ambiente;

- Identificação das necessárias ações corretivas e preventivas, em função dos resultados dessas medições e monitoramentos;

- Identificação, manutenção e descarte de registros ambientais: tais registros podem incluir informações sobre processos e produtos, registros de inspeção, manutenção e calibração, e informações pertinentes relativas a prestadores de serviços e fornecedores;

- Auditorias do SGA: devem ser realizadas periodicamente para determinar a conformidade do sistema ao que foi planejado e verificar se ele vem sendo adequadamente implementado e mantido. Podem ser conduzidas por pessoal da própria organização ou por terceiros por ela selecionados (ABNT, 1996b).

\section{$\underline{\text { Análise crítica }}$}

Deve ser feita periodicamente pela administração da organização, e incluir, segundo a ISO 14004: 
- análise de objetivos, metas e desempenho ambientais;

- constatações das auditorias do SGA, e avaliação de sua eficácia;

- avaliação da adequação da política ambiental e da necessidade de alterações, em vista de mudanças na legislação, nas expectativas e requisitos das partes interessadas, nos produtos ou atividades da organização, nas preferências do mercado, entre outros fatores.

Por fim, a melhoria contínua é atingida através da avaliação contínua do desempenho ambiental do SGA em relação à política, objetivos e metas ambientais. Para tal, é necessário:

- identificar oportunidades de melhoria do desempenho ambiental;

- determinar causas de não-conformidades ou deficiências;

- desenvolver e implementar plano de ações corretivas e preventivas;

- verificar a eficácia dessas ações;

- documentar alterações ocorridas nos procedimentos;

- comparar os resultados com os objetivos e metas (ABNT, 1996b).

Em resumo, pode-se afirmar que a norma ISO 14001 está fundamentada no funcionamento de um processo cíclico, em que a prevenção da poluição figura como peça chave para a melhora constante do desempenho ambiental e econômico de uma organização.

\subsection{Análise de Ciclo de Vida (ACV)}

Anteriormente, já foi apresentado o conceito de fluxo de materiais e processos, a seqüência que vai da extração das matérias-primas até o tratamento e posterior disposição final. Ampliando-se este conceito, de modo a abranger também os processos de reuso, reciclagem e recuperação, esta seqüência é transformada, ao menos teoricamente, em um ciclo fechado. Chega-se então, ao termo ciclo de vida, que descreve a seqüência de processos e atividades associadas a um certo produto, da extração de matérias-primas até a reciclagem, reutilização e recuperação de materiais, ou a disposição final dos resíduos considerados inservíveis. 
Isto posto, define-se Análise de Ciclo de Vida como um processo que avalia os aspectos ambientais e impactos associados ao ciclo de vida de um produto, identificando, por exemplo, as quantidades de energia e matéria-prima utilizadas em cada etapa (ABRE, 2003b). De acordo com Bishop (2000), tais processos analisam as interações da empresa com as ações de seus fornecedores e consumidores, e o resultado, dessa forma, é uma análise completa ("cradle-to-the-grave") do impacto ambiental de um produto. Autores como Chehebe (1997) utilizam, ainda, a expressão "da terra à terra" para indicar que a ACV abrange todos os estágios do ciclo de vida de um produto : extração e processamento dos recursos naturais, manufatura, uso/reuso e disposição final.

O estudo consiste no desenvolvimento de modelos que descrevam os elementos chaves do sistema físico em questão. A escolha desses elementos depende dos objetivos e do escopo do estudo, isto é, da aplicabilidade dos resultados e do nível de detalhes desejado, de modo que o estudo seja gerenciável, prático, econômico e, ao mesmo tempo, produza resultados confiáveis (CHEHEBE, 1997).

A ISO 14040, norma que dispõe sobre os procedimentos gerais da ACV, determina a divisão do estudo em 4 fases:

- definição dos objetivos e do alcance (escopo);

- levantamento dos dados;

- avaliação dos impactos;

- interpretação dos resultados.

Os resultados serão aplicados conforme determinado no objetivo do estudo. A ACV, de acordo com Chehebe (1997), é uma ferramenta técnica de caráter gerencial, que permite à empresa saber mais sobre seus processos e seu desempenho, sobretudo nos aspectos ambientais. Pode ser realizada com inúmeros propósitos:

- avaliação dos aspectos ambientais do processo produtivo: permite comparar processos que visam ao mesmo objetivo, ajudando a determinar qual o menos impactante;

- avaliação de desempenho de produtos, através da análise de indicadores associados a eles;

- apoio à decisão na compra de materiais: quantifica e compara o desempenho ambiental de materiais similares;

- auxílio ao projeto de produtos: permite a análise das alternativas possíveis, não só quanto à forma, mas também quanto à composição dos componentes do projeto; 
- identifica prioridades e oportunidades de melhoria, afastando-se do enfoque "fim-de-tubo" dado à proteção ambiental;

- dá subsídio consistente a estratégias de marketing, ao contrário de outras análises menos completas do sistema produtivo.

Todos esses objetivos podem ser aplicados tanto para revisar os processos e remodelar os produtos já existentes, com o objetivo de adequá-los a novas realidades ou requisitos mercadológicos, como para o desenvolvimento de novos produtos, tendo em vista essas novas exigências desde o início do projeto.

\subsubsection{Histórico da Análise de Ciclo de Vida}

Segundo Chehebe (1997), os primeiros estudos que podem ser considerados análises do ciclo de vida de produtos datam de meados da década de 60 e visavam, principalmente, a otimização do consumo de energia, numa tentativa de mitigar o impacto da crise energética mundial desencadeada a partir daquela época, pelos sucessivos aumentos do preço do petróleo.

Mais recentemente, a busca pelo chamado "desenvolvimento sustentável" constituiu novo impulso ao desenvolvimento de instrumentos gerenciais que permitissem a conciliação de desenvolvimento econômico com a prevenção e redução nos impactos ao meio ambiente. A Análise do Ciclo de Vida mostrou-se peça importante na busca da sustentabilidade por parte da indústria, que cunhou o termo "eco-eficiência" para designar a condição de competitividade econômica aliada a desempenho ambiental (CHEHEBE, 1997).

$\mathrm{O}$ processo de desenvolvimento da $\mathrm{ACV}$, no entanto, foi marcado por inúmeras dificuldades e acontecimentos que, em certo momento, ameaçaram até mesmo sua credibilidade como instrumento gerencial. Tal estudo requer a análise de inúmeras entradas e saídas de processos freqüentemente complexos, o que dificultou a elaboração e padronização de metodologias adequadas, e, ao mesmo tempo, levou muitos profissionais a desconsiderar certas etapas e informações ao realizar tais estudos. Estas omissões podem resultar em graves erros de avaliação que comprometem, às vezes totalmente, o resultado da análise. Muitas empresas, na ânsia de utilizar esta ferramenta como simples instrumento de marketing, realizaram ou encomendaram diversos estudos com base em análises de ciclo de vida, alguns deles publicados no início da década de 90. Quando comparados, alguns desses estudos mostram diferenças gritantes nos 
resultados, o que leva a crer que, intencionalmente ou não, apenas os dados que interessavam às empresas foram publicados (CHEHEBE, 1997).

Esse comportamento tendencioso de algumas das primeiras ACV's acabou por colocar em xeque a precisão e a credibilidade do estudo. Porém, diversos institutos passaram a desenvolver pesquisas na tentativa de desenvolver metodologias confiáveis para a realização dessas análises. Manzini \& Vezzoli (2002) relatam que a SETAC (Society of Environmental Toxicology and Chemistry) foi o primeiro organismo a avaliar essas diversas experiências que estavam sendo desenvolvidas, de modo a definir objetivos, critérios e termos comuns para o desenvolvimento da ACV.

O trabalho da SETAC constituiu a base para a elaboração, pela ISO (International Organization for Standardization), de normas que norteassem a realização desses estudos. Em 1997, foi publicada a norma ISO 14040, que determinava as normas e procedimentos gerais para a realização da Análise de Ciclo de Vida, que desse modo, alcançou reconhecimento como ferramenta "científica".

\subsubsection{A ACV nas normas ISO e legislações}

Até o momento, a ISO publicou uma série de normas relacionadas à $\mathrm{ACV}$, bem como relatórios técnicos, identificados pela sigla TR, relativos à aplicação de algumas delas. No Brasil, a ABNT é responsável pela publicação das normas NBR-ISO (ver Apêndice II).

A ACV também já tem sido objeto de medidas governamentais em diversos países; legislações no Japão, Estados Unidos e em países europeus já consideram a importância desse estudo. Um exemplo é o "Life Cycle and Waste Management Act", aprovado pelo governo alemão em meados da década de 90, e que determinou metas e prazos para a implantação, nas indústrias, de programas de ciclo de vida para vários produtos, além das embalagens. Considera ainda, a adoção de medidas que obriguem diversas companhias associadas a um produto específico a fornecer uma série de informações ambientais relativas a cada estágio do processo de manufatura do produto (ECOCYCLE, 2003). 


\subsection{Tendências atuais no setor de embalagem}

O setor de embalagens pode e deve acompanhar a tendência atual em direção à prevenção na geração de resíduos. Os conceitos e técnicas gerenciais desenvolvidos recentemente são utilizáveis tanto pelos fabricantes de embalagens como pelas indústrias que utilizam as embalagens e que, cedo ou tarde, terão de gerenciar os resíduos resultantes.

Exemplo disso é a realização de projetos que envolvem ACV's; tais estudos têm sido desenvolvidos, abordando tanto embalagens quanto produtos alimentícios acondicionados, visando a atualização dos bancos de dados básicos necessários à análise: energia elétrica, transporte e gerenciamento de resíduos sólidos (CETEA, 2004).

As técnicas de prevenção da poluição mais eficazes são as que incluem o conceito de "design for the environment", ou projeto para o ambiente. BISHOP (2000) aponta a íntima relação entre o design for the environment e a Análise de Ciclo de Vida do produto, uma vez que ambos envolvem o refinamento de um processo de fabricação ou mesmo do próprio produto. Assim, para ser efetivo, o projeto deve sempre considerar todos os aspectos do produto e de seu processo de fabricação, incluindo a seleção de materiais e seleção do processo de manufatura.

Para descrever um projeto como esse, que considera todos os aspectos do ciclo de vida de um produto, Pinatti (1999) emprega o termo ecodesign. Para o pesquisador, o ecodesign (ou ecoprojeto) é a visão ecológica do design industrial; seu objetivo é o projeto de produtos com menor impacto ambiental, uso correto e reaproveitamento dos materiais, menor consumo de energia, preocupação com a embalagem e seu destino. A aplicação do ecoprojeto às embalagens está expressa em algumas das recomendações da ABRE (2003b):

- na escolha de material: levar em consideração fatores como toxidez, escassez, renovabilidade e reciclabilidade;

- no projeto: evitar 'overpacking' (uso desnecessário ou excessivo de embalagens); considerar a 'desmontagem' da embalagem; reduzir a espessura das paredes da embalagem; priorizar rótulos que não utilizam cola e embalagens incolores, pois as tintas aplicadas às embalagens podem não ser quimicamente compatíveis com o material, prejudicando a reciclagem; intensificar o uso de refil; disponibilizar ao consumidor todas as informações referentes à embalagem; 
- otimização da função do produto: prolongar o tempo de vida útil do produto; maximizar as possibilidades de reaproveitamento.

Conceitos como os apresentados até aqui refletem a preocupação na redução da poluição ainda na fase de projeto. Outras ferramentas, porém, visam a valorização dos resíduos já gerados, transformando-os, por exemplo, em fonte de matérias-primas; é o caso das chamadas bolsas de resíduos. Consistem basicamente em um sistema que reúne, de um lado, indústrias geradoras de resíduos, que anunciam e disponibilizam os resíduos que geram, e, de outro, indústrias que manifestam interesse na compra de determinados tipos de rejeitos.

As bolsas de resíduos não são exatamente uma idéia nova. Dorn \& McAdams (1982) já discorriam sobre o funcionamento do sistema: a bolsa mantém listagens de empresas interessadas na compra de certos tipos de resíduos e de empresas que disponibilizam seus resíduos, sendo que os nomes destas são mantidos em sigilo, para que não sejam reveladas informações que beneficiem concorrentes ou causem desconfiança do público. Companhias que venham a interessar por certo tipo de resíduos anunciados contatam a bolsa, que encaminha seu pedido para a firma listada. A transação ente as firmas é, então, realizada, desde que atenda a algumas condições de viabilidade:

- técnica: as propriedades físico-químicas dos resíduos devem atender às especificações estabelecidas para a matéria-prima;

- econômica: os custos de administração e transporte do processo de transferência devem compensar os custos de disposição ou de aquisição de matériaprima "virgem".

- institucional: o gerador e o futuro usuário dos resíduos devem se sentir “confortáveis" ao fazer negócios um com o outro, e a transferência deve ser permitida pela lei.

Em princípio, qualquer empresa geradora de resíduos potencialmente reutilizáveis ou recicláveis, ou que possa substituir matéria-prima virgem por algum tipo de material já utilizado pode se beneficiar da associação a uma bolsa de resíduos, afirmam os autores. Segundo eles, tais sistemas se caracterizam por divulgar produtos com valor relativamente pouco conhecido, que são tidos simplesmente como resíduos e não como subprodutos; desse modo, não competem com outros intermediários ou negociantes de subprodutos químicos, industriais ou comerciais. 
A bolsa, ao reunir e facilitar a transação entre essas empresas, permite a um só tempo, que a geradora de resíduos se livre de material que, inútil para ela, teria que ser tratado e disposto adequadamente, e que as compradoras possam ter acesso a resíduos que são, para ela, matérias-primas e que, se não fossem assim adquiridas, teriam de ser obtidas através da exploração de reservas naturais virgens, o que contribuiria para o esgotamento destas; acrescente-se a isso o fato de que obter recursos a partir desses resíduos requer menos energia do que extraí-los da natureza. Dessa forma, as bolsas de resíduos podem, em tese, diminuir a necessidade por sistemas de tratamento, instalações de disposição e utilização de reservas naturais, contribuindo indiretamente para a redução na geração de resíduos.

No entanto, Fonseca et al. (2005) ressaltam que boa parte das Bolsas instaladas no país não tem apresentado resultados condizentes com os objetivos esperados; tais organismos ainda precisam ser mais eficazes como intermediadores, inclusive visando lucros com as negociações entre as empresas participantes, o que ajudaria a sustentar a estrutura necessária ao bom funcionamento do sistema, e garantiria um maior controle sobre a movimentação ocorrida e os resultados obtidos. Os autores ainda consideram necessário incentivar programas de cooperação com os órgãos ambientais, buscando maior agilidade na obtenção da documentação legal exigida para a identificação e comercialização de resíduos industriais.

\subsection{Experiências de gerenciamento: o caso da Comunidade Econômica}

\section{Européia}

A Comunidade Econômica Européia foi instituída por meio do Tratado de Roma, ou Tratado da CEE, assinado em 25 de março de 1957. O Tratado de Maastricht, ou Tratado da União Européia - TUE, firmado em 7 de fevereiro 1992, alterou o Tratado de Roma, instituindo a União Européia ${ }^{5}$ (EUROPA, 2004).

De modo geral, os tratados de Roma e Maastricht visaram à criação de um mercado comum entre os países daquela região, estabelecendo uma união econômica e monetária e a necessidade de aplicação de políticas e ações comuns. O texto atualizado

5 Atualmente, 25 países fazem parte da União Européia: Áustria, Bélgica, Chipre, República Tcheca, Dinamarca, Estônia, Finlândia, França, Alemanha, Grécia, Hungria, Irlanda, Itália, Letônia, Lituânia, Luxemburgo, Malta, Países Baixos, Polônia, Portugal, Eslováquia, Eslovênia, Espanha, Suíça e Reino Unido (EUROPA, 2004). 
do tratado da CEE apresenta, em seu artigo $3^{\circ}$. da parte $\mathrm{I}$, as ações previstas para o estabelecimento da União, entre as quais destacam-se:

“- Uma política comercial comum;

- Um mercado interno caracterizado pela abolição, entre os EstadosMembros, dos obstáculos à livre circulação de mercadorias, de pessoas, de serviços e de capitais;(...)

- A aproximação das legislações dos Estados-Membros na medida do necessário para o funcionamento do mercado comum;(...)

- Uma política no domínio do ambiente (grifo nosso);.

- O reforço da capacidade concorrencial da indústria da Comunidade.

- A promoção da investigação e do desenvolvimento tecnológico.(...)"

Nesse contexto, têm sido adotadas uma série de diretivas, de modo a coordenar as ações daquele bloco de países nas áreas econômica, monetária, administrativa e ambiental, entre outras.

\subsubsection{A diretiva $94 / 62$}

De especial interesse para o presente texto é a diretiva 94/62, que visa unificar as disposições e medidas nacionais relativas à gestão das embalagens e dos resíduos de embalagens. Entre os pontos principais enfocados pelo texto estão:

- prevenção;

- reutilização;

- valorização e reciclagem;

- sistemas de recuperação, coleta e valorização;

- normalização;

- sistemas de informação - bases de dados;

- informações para os utilizadores das embalagens.

O texto, de início, tece considerações sobre a necessidade da redução dos resíduos, “condição necessária para o crescimento sustentável expressamente mencionado no Tratado da União Européia”. Determina que a estratégia de gestão de embalagens e resíduos de embalagens:

“incluirá, como primeira prioridade, a prevenção da produção de resíduos de embalagens (grifo nosso) e, como princípios fundamentais, a reutilização de embalagens, a reciclagem e outras formas de valorização dos resíduos de embalagens e, por conseguinte, a redução da eliminação final de tais resíduos; (...)" 
A seguir, são apresentados e discutidos alguns artigos merecedores de destaque.

$\mathrm{O}$ artigo $1^{\circ}$ apresenta os objetivos da diretiva, entre os quais está o de harmonizar as disposições dos países-membros relativas à gestão de embalagens e de resíduos de embalagens, a fim de prevenir e reduzir os impactos ambientais. Estabelece como prioridade a prevenção da produção de resíduos de embalagens, tendo como princípios fundamentais a reutilização e a reciclagem, entre outras formas de valorização dos resíduos de embalagens.

$\mathrm{O}$ artigo $2^{\circ}$ declara que a diretiva abrange todas as embalagens colocadas no mercado da Comunidade e todos os resíduos de embalagens, sejam eles utilizados ou produzidos na indústria, no comércio, em escritórios, lojas ou serviços, em residências ou em qualquer outro nível, e independentemente do material utilizado.

Os artigos $4^{\circ}$ e $5^{\circ}$ discorrem, respectivamente, sobre a prevenção e a reutilização: os países-membros devem assegurar que sejam tomadas medidas de prevenção, como programas de ação nacionais, bem como incentivar o uso de sistemas de reutilização das embalagens susceptíveis de serem reutilizadas.

O artigo $6^{\circ}$ estabelece metas para reciclagem dos resíduos de embalagens.

Segundo o artigo $7^{\circ}$, os países-membros deverão assegurar a criação de sistemas que garantam:

- a coleta e recuperação das embalagens usadas e resíduos de embalagens provenientes do consumidor ou de qualquer outro utilizador final ou do fluxo de resíduos, destinando-os para as soluções alternativas de gestão mais adequadas;

- a reutilização ou valorização, incluindo a reciclagem das embalagens e dos resíduos de embalagens recolhidos.

As embalagens, de acordo com o artigo $8^{\circ}$, indicarão a natureza dos materiais utilizados, para efeitos de identificação e classificação pela respectiva indústria, a fim de facilitar a coleta, reutilização e valorização, incluindo a reciclagem. A marcação adequada será aplicada no rótulo ou na própria embalagem; deve ser claramente visível, de fácil leitura e ter uma duração adequada, inclusivamente depois da abertura da embalagem.

No artigo $10^{\circ}$, prevê-se a elaboração de normas européias relativas aos requisitos essenciais relativos à composição e à possibilidade de reutilização, valorização ou reciclagem das embalagens; em especial, regulamentos sobre:

- critérios e metodologias de análise do ciclo de vida da embalagem; 
- métodos de medição e verificação da presença de metais pesados e de outras substâncias perigosas na embalagem e sua libertação no ambiente a partir de embalagens e resíduos de embalagens;

- critérios referentes à existência de um teor mínimo de material reciclado nas embalagens, para tipos de embalagem adequados;

- critérios a adotar quanto aos métodos de reciclagem, de compostagem e de marcação das embalagens.

Segundo o artigo $12^{\circ}$, os países membros têm a responsabilidade de criar cada qual sua própria base de dados relativos às embalagens e resíduos de embalagens em cada país-membro. Essas bases de dados devem fornecer informações sobre volume, características e evolução dos fluxos de embalagens e resíduos de embalagens (incluindo informações sobre o conteúdo tóxico ou perigoso dos materiais de embalagem e dos componentes utilizados no seu fabrico).

Por fim, o artigo $13^{\circ}$ estabelece que os países-membros devem adotar medidas que assegurem que todos os utilizadores de embalagens, em especial os consumidores finais, disponham de informações necessárias sobre:

- sistemas de coleta e recuperação de que dispõem;

- a possibilidade de contribuírem para reutilização e reciclagem de embalagens e resíduos de embalagens;

- o significado das marcações nas embalagens existentes no mercado;

- planos de gestão das embalagens e resíduos de embalagens.

A diretiva apresenta, em seu anexo II, requisitos essenciais relativos à composição e às possibilidades de reutilização, valorização ou reciclagem das embalagens. Alguns exemplos:

- as embalagens devem ser concebidas, produzidas e comercializadas de modo a permitir a sua reutilização, valorização ou reciclagem e a minimizar o impacto ambiental quando da disposição de seus resíduos;

- na fabricação das embalagens deve-se minimizar a presença de substâncias nocivas e outras substâncias e matérias perigosas no material utilizado;

- as propriedades físicas e características das embalagens devem permitir um certo número de viagens ou ciclos de utilização.

Há, ainda, requisitos específicos para embalagens biodegradáveis; estas deverão ter características que permitam a decomposição física, química, térmica ou biológica 
que garanta que a maioria do composto acabe por se decompor em dióxido de carbono, biomassa e água.

\subsubsection{Selos de qualidade ambiental na Europa}

Os selos de qualidade ambiental funcionam como um complemento da legislação ambiental uma vez que, de modo geral, não são obrigatórios por lei; em outras palavras, sua adoção pelas empresas ocorre não por força de legislação, mas por pressões sobretudo mercadológicas. Alguns deles, os chamados "rótulos tipo I", baseiam-se na análise do ciclo de vida do produto em questão, e são concedidos não pelo fabricante, e sim por terceiros, isto é, organismos devidamente credenciados.

A criação dos "selos verdes" ocorreu de forma isolada por uma série de entidades de diversos países, e acabou levando à criação de normas internacionais como a ISO 14024, referente a programas de rotulagem ambiental (MOURA, 2004). A adoção de um selo de qualidade ambiental confere imagem positiva à empresa, e facilita sua entrada em determinados mercados mais exigentes.

O site da Câmara de Comércio Brasil-Alemanha apresenta uma relação de selos de qualidade ambiental de uso freqüente na Europa. Alguns deles são concedidos para produtos e equipamentos de segurança comprovada, e outros para produtos em conformidade com as diretrizes da Comunidade Econômica Européia. Outros, ainda, estão voltados para a certificação ambiental de produtos e serviços. É o caso dos selos apresentados a seguir.

\section{Ponto Verde (Grüner Punkt)}

O "Sistema Dual" baseado no Regulamento de Embalagem, utiliza este símbolo:

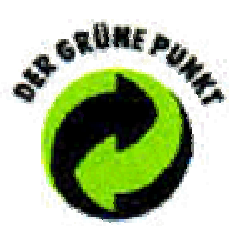

Figura 7 - O Ponto Verde (Fonte: Câmara de Com. e Ind. Brasil-Alemanha, 2004)

O sistema obriga o comércio e a indústria a recolher e aproveitar os materiais das embalagens de transporte e venda para sua reciclagem e reutilização. Varejistas e fabricantes poderão ser dispensados de sua obrigação individual de admitir a devolução de embalagens se participarem de um sistema amplo e acessível publicamente para a 
coleta, separação e reciclagem de embalagens usadas. Esse sistema público é executado pela empresa Duales System Deutschland AG.

Caso o produtor de bens destinados ao consumidor final não tenha um sistema individual de reciclagem das embalagens, deve recolher uma taxa ao sistema, que se encarrega de reciclar as embalagens utilizadas por estes bens colocados em circulação. O pagamento desta taxa autoriza o produtor ou importador a utilizar o selo "Ponto Verde".

A Duales System tem que publicar anualmente seus dados de desempenho, através de um documento chamado verificação do fluxo de material. De posse deste documento, a empresa pode demonstrar aos Ministérios de Meio Ambiente dos estados alemães que as embalagens pós-consumidor são devidamente coletadas, separadas e recicladas.

\section{$\underline{\text { Anjo Azul (Blauer-Engel) }}$}

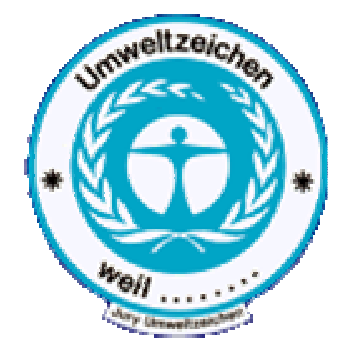

Figura 8 - O Anjo Azul (Fonte: Câmara de Com. e Ind. Brasil-Alemanha, 2004)

O Anjo Azul é utilizado desde 1978 no mercado ambiental como símbolo para produtos ou serviços com impacto ambiental reduzido ou positivo. Para receber este selo, um produto, além de ter as características de funcionalidade e segurança iguais aos similares, precisa apresentar consideráveis vantagens ambientais. Para tal, a empresa fabricante deve considerar todos os aspectos ambientais envolvidos, como a preservação de recursos naturais.

O selo contém, em seu centro, o símbolo de meio ambiente das Nações Unidas, a figura azul com os braços abertos, que levou o selo a ter o nome popular, não-oficial, de Anjo Azul. Contém, ainda, os dizeres "selo ambiental porque...", que fazem referência às principais características ambientais do produto. Exemplos: "porque é feito de plástico reciclado", "porque não contém mercúrio e cádmio". 
O Anjo Azul é propriedade do Ministério de Meio Ambiente, Proteção da Natureza e Segurança Atômica da Alemanha e é concedido, por prazo determinado, por uma comissão julgadora independente. Faz parte dos instrumentos ambientais ditos "brandos", pois é totalmente voluntário: sua ausência não resulta em nenhuma restrição ou proibição ao produto. No entanto, a Câmara informa que cerca de 4000 produtos estão atualmente autorizados a utilizar o Anjo Azul.

Produtos ou serviços de uma empresa não sediada na Alemanha também podem receber o Anjo Azul; 13\% das permissões de utilização do selo foram concedidas para empresas de outros países. Entre os produtos que podem ser analisados para a concessão do selo estão: garrafas reutilizáveis, papelão reciclado, material de construção de vidro reciclado e embalagens de transporte reutilizáveis, entre muitos outros.

Também podem ser citados selos como o canadense Environmental Choice, o japonês Eco Mark, e o Energy Saver e o Green Seal, ambos utilizados nos Estados Unidos (MOURA, 2004).

\subsection{Brasil: situação atual}

\subsubsection{Estatísticas}

É sintomático o fato de o texto da resolução CONAMA 313, que será discutida mais adiante, incluir a passagem:

“(...) Considerando a ausência de informações precisas sobre a quantidade, os tipos e os destinos dos resíduos sólidos gerados no parque industrial do país;(...)"

De fato, além de números sobre a reciclagem, como os divulgados pelo CEMPRE e apresentados no item 3.4.1, há poucas informações estatísticas relativas ao setor. Mesmo essas estatísticas apontam números relativos aos materiais; não são números específicos referentes à geração de resíduos de embalagens. Conseqüentemente, não se dispõe, no Brasil, de números precisos referentes à geração de resíduos de embalagens de uso industrial. São encontrados apenas dados sobre a produção de embalagens, como os obtidos pela Fundação Getúlio Vargas e divulgados pela ABRE (Associação Brasileira de Embalagem), em seu site: 


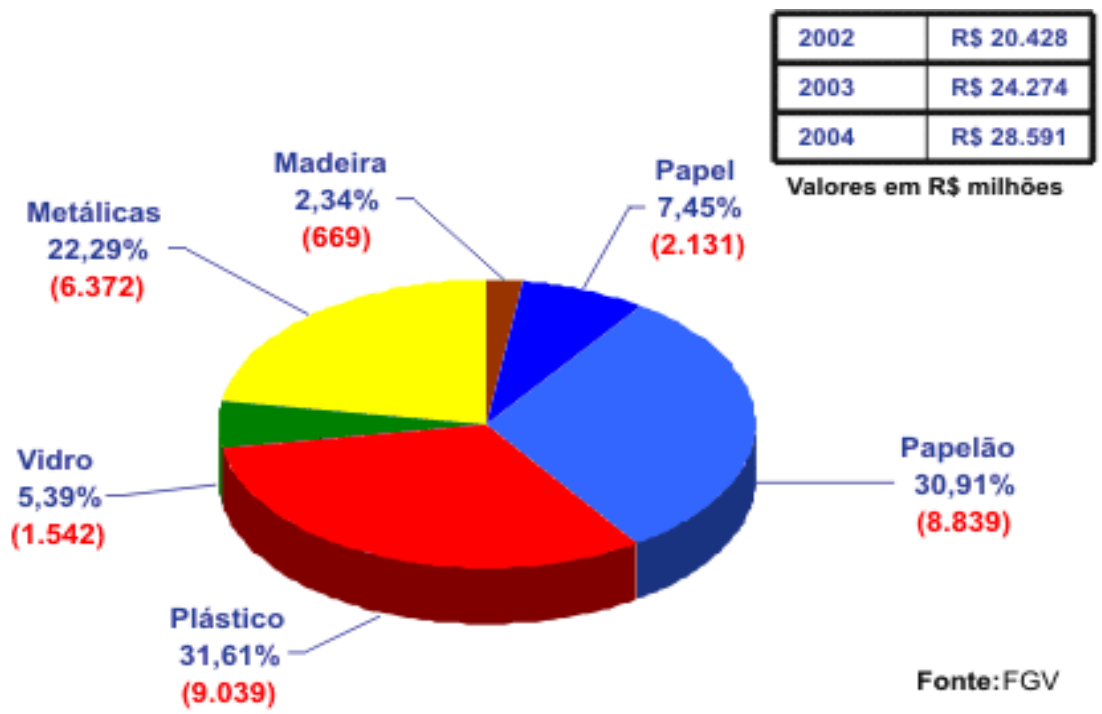

Figura 9 - Faturamento e divisão do setor de embalagens. Fonte: ABRE (2005a)

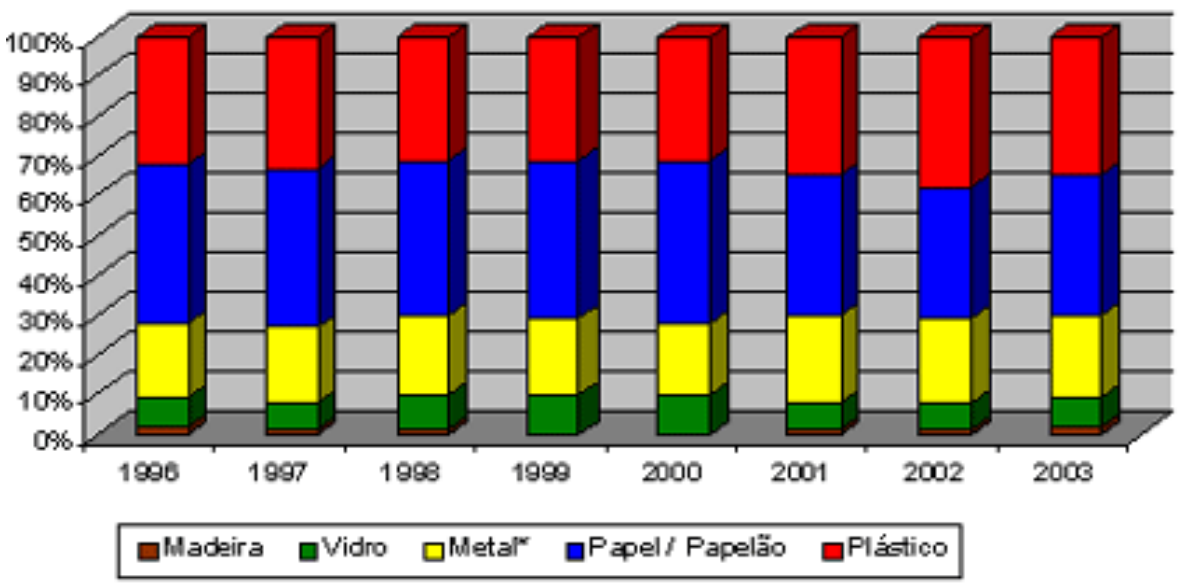

Figura 10 - Participação de materiais no mercado. Fonte: ABRE (2005a)

\subsubsection{Legislação federal}

Conforme ressalta Valle (2002), até o início da década de 70 não havia legislação que abordasse especificamente a questão ambiental no Brasil; apenas normas e regulamentos que tratavam da saúde pública, da proteção à fauna e à flora, e da segurança e higiene industrial.

O processo de criação da legislação ambiental brasileira, de acordo com Alemeida (1998), inicia-se após as reações negativas à posição do Brasil na Conferência das Nações Unidas sobre Meio Ambiente Humano (Estocolmo, 1972). No encontro, a 
delegação brasileira defendeu a priorização do crescimento industrial em detrimento dos aspectos ambientais.

Em meados da década de 70, aponta a autora, a questão ambiental passou a integrar o planejamento governamental, estando presente no II Plano Nacional de Desenvolvimento (II PND). Nessa mesma época, surgiram as primeiras leis específicas sobre a matéria, e são criados os primeiros órgãos ambientais estaduais: a CETESB, em São Paulo, e a FEEMA, no Rio de Janeiro; originalmente voltados para o saneamento básico, ampliaram suas atividades, passando a tratar também de questões como a poluição industrial.

Os anos 80 trouxeram avanços na política ambiental, refletido na aprovação de leis significativas e na promulgação da Constituição de 1988, que dedicou um capítulo inteiro à questão ambiental. Em 1992, ocorre a transformação da Secretaria do Meio Ambiente - SEMAM no Ministério do Meio Ambiente (MMA).

A legislação atual aborda os problemas da contaminação ambiental em três planos distintos:

- locais de produção: visa reduzir os impactos ambientais resultantes das atividades - controle na origem da geração de resíduos e emissões;

- produtos: visa restringir o uso de certos materiais perigosos, e estabelecer limites aos impactos causados pela utilização e descarte;

- condições ambientais: limitar, em casos extremos, certas atividades que possam afetar os ecossistemas da região ou área em que estão instaladas ou mesmo, em casos mais graves, o ambiente global (VALLE, 2002).

São apresentadas a seguir algumas das leis mais significativas no tocante à questão ambiental, principalmente no caso das indústrias.

\section{Decreto-Lei 1413, de 14 de agosto de 1975}

Dispõe sobre o controle da poluição do meio ambiente provocada por atividades industriais. Estabelece a necessidade, por parte das empresas, de prevenirem ou corrigirem os inconvenientes e prejuízos da poluição; prevê medidas de zoneamento, para determinar locais adequados para instalação de indústrias, e de alternativas para nova localização de determinados empreendimentos, nos casos mais graves, bem como o estabelecimento, por parte de estados e municípios, de condições para o funcionamento de empreendimentos. 


\section{Decreto 76389 , de 3 de outubro de 1975}

Regulamenta o Decreto-Lei 1413/75, dispondo sobre as medidas de prevenção e controle da poluição industrial por ele determinadas. Prevê critérios, normas e padrões para evitar e corrigir as consequiências deste tipo de poluição, destacando novamente a possibilidade de os estados e municípios estabelecerem tais, e determina a aplicação de penas aos infratores.

Se por um lado, o texto discorre sobre medidas de controle da poluição, por outro, apresenta, no parágrafo único do art $3^{\circ}$ a seguinte redação:

"No estabelecimento de critérios, normas e padrões acima referidos, será levada em conta a capacidade autodepuradora da água, do ar e do solo, bem como a necessidade de não obstar indevidamente o desenvolvimento econômico e social do País (grifo nosso)."

A preocupação em explicitar a necessidade de manutenção do crescimento econômico talvez seja um indício de que a posição defendida pelo governo brasileiro na conferência de Estocolmo ainda não havia mudado totalmente.

\section{$\underline{\text { Lei Federal 6803, de } 2 \text { de julho de } 1980}$}

Dispõe sobre as diretrizes básicas para o zoneamento industrial nas ditas áreas críticas de poluição. Classifica as zonas destinadas à instalação industrial em três tipos: zonas de uso estritamente industrial, de uso predominantemente industrial e de uso diversificado; prevê o enquadramento das indústrias já existentes nessas zonas industriais, mediante instalação de equipamentos especiais de controle, e até mesmo à mudança de local, se necessário; determina também a classificação dessas zonas, segundo padrões pré-determinados, em não saturadas, em vias de saturação e saturadas. Para cada tipo, devem ser aplicadas normas diferenciadas para o licenciamento de indústrias e a implementação de programas de controle da poluição.

A lei, por fim, condiciona a obtenção de licença para implantação, operação e ampliação de estabelecimentos industriais nas áreas críticas de poluição à observância do disposto em seu texto, e ao atendimento de normas e padrões ambientais definidos. 


\section{Lei Federal 6938, de 31 de agosto de 1981}

Institui e dispõe sobre a Política Nacional do Meio Ambiente. Tornou-se, no entender de autores como Almeida (1998), um marco do avanço brasileiro em termos de estrutura legal e do tratamento das questões ambientais. As questões ambientais passaram a ser tratadas de forma integrada: o objetivo não era simplesmente garantir a preservação de recursos naturais, mas também seu uso racional, através do disciplinamento de atividades potencialmente poluidoras, além do estímulo de ações educativas e de incentivo a pesquisas no setor (SOUSA, 2000).

De fato, a Política visa, segundo o art. $2^{\circ}$. da lei, à "preservação, melhoria e recuperação da qualidade ambiental propícia à vida”, através de atividades e mecanismos como:

- incentivo ao estudo e à pesquisa de tecnologias nacionais que permitam a racionalização do uso e preservação do solo, subsolo, água e ar e demais recursos naturais;

- planejamento e fiscalização do uso dos recursos ambientais;

- controle e zoneamento das atividades potencial ou efetivamente poluidoras;

- educação ambiental a todos os níveis do ensino, com vistas à conscientização da comunidade;

- difusão de tecnologias de manejo do meio ambiente;

- divulgação de dados e informações ambientais.

Para atingir estes objetivos, a Política conta com instrumentos como:

- o estabelecimento de padrões de qualidade ambiental;

- o zoneamento ambiental;

- a avaliação de impactos ambientais;

- o licenciamento e de atividades efetiva ou potencialmente poluidoras;

- incentivos à produção e instalação de equipamentos e a criação ou absorção de tecnologia.

No art. $5^{\circ}$., parágrafo único, a lei explicita que "as atividades empresariais públicas ou privadas serão exercidas em consonância com as diretrizes da Política Nacional do Meio Ambiente".

Chama-se a atenção também para o artigo 13, segundo o qual o Poder Executivo incentivará atividades voltadas ao meio ambiente, visando: 
“(...) ao desenvolvimento, no País, de pesquisas e processos tecnológicos destinados a reduzir a degradação da qualidade ambiental;

II - à fabricação de equipamentos antipoluidores;

III - a outras iniciativas que propiciem a racionalização do uso de recursos ambientais (...)"”

Ainda conforme o artigo 13, entre as metas prioritárias dos órgãos e programas de incentivo à pesquisa científica e tecnológica, deve estar o apoio a projetos que tenham o objetivo de adquirir e desenvolver conhecimentos básicos e aplicáveis na área ambiental e ecológica.

\section{$\underline{\text { Lei Federal 7347, de } 24 \text { de julho de } 1985}$}

Disciplina a ação civil pública de responsabilidade por danos causados ao meio ambiente, consumidor e outros.

A lei determina que danos morais e patrimoniais causados ao meio ambiente, ao consumidor, à ordem urbanística, a bens e direitos de valor artístico, estético, histórico, turístico e paisagístico, a qualquer outro interesse difuso ou coletivo podem ser passíveis de ação civil pública. Seu artigo $4^{\circ}$ prevê, inclusive, a possibilidade de se mover ação de modo a evitar que o dano venha a ser causado.

A ação poderá ser proposta pelo Ministério Público, pela União, pelos Estados e Municípios e também por autarquia, empresa pública, fundação, sociedade de economia mista ou por associação que esteja constituída há pelo menos um ano, nos termos da lei civil, e tenha como uma de suas finalidades institucionais a proteção ao meio ambiente ao consumidor, à ordem econômica, à livre concorrência, ou ao patrimônio artístico, estético, histórico, turístico e paisagístico.

\section{Constituição Federal, promulgada em 5 de outubro de 1988}

A Constituição brasileira estabelece, em seu art. 174, que o Estado, na condição de responsável pela normatização e regulação de atividades econômicas, deve exercer "na forma da lei”, as funções de fiscalizar, incentivar e planejar, e que o planejamento deve ser "determinante para o setor público e indicativo para o setor privado".

O Capítulo VI do Título VIII - Da Ordem Social - é intitulado "Do Meio Ambiente" e é composto pelo artigo 225. Segundo o parágrafo $1^{\circ}$ deste, o Poder Público está incumbido de:

"I - preservar e restaurar os processos ecológicos essenciais e prover o manejo ecológico das espécies e ecossistemas;(...) 
III - definir, em todas as unidades da Federação, espaços territoriais e seus componentes a serem especialmente protegidos, sendo a alteração e a supressão permitidas somente através de lei, vedada qualquer utilização que comprometa a integridade dos atributos que justifiquem sua proteção; IV - exigir, na forma da lei, para instalação de obra ou atividade potencialmente causadora de significativa degradação do meio ambiente, estudo prévio de impacto ambiental, a que se dará publicidade;

V - controlar a produção, a comercialização e o emprego de técnicas, métodos e substâncias que comportem risco para a vida, a qualidade de vida e o meio ambiente; (...)"

\section{Lei 9605 , de 12 de fevereiro de 1998}

É também conhecida por Lei dos Crimes Ambientais, uma vez que dispõe sobre as sanções penais e administrativas aplicadas em caso de conduta ou atividade lesiva ao meio ambiente. Determina, em seu art. $2^{\circ}$, que as penas devem ser aplicadas a quem contribui para a prática dos crimes previstos no texto e também a quem tenha conhecimento de conduta criminosa e não a impede, mesmo tendo possibilidade - pune o crime por ação e por omissão.

Entre as sanções previstas no texto está a chamada pena de interdição temporária de direito, que impossibilita o culpado de firmar contrato com o Poder Público, receber incentivos fiscais ou qualquer outro tipo de benefício, bem como participar de licitações.

$\mathrm{O}$ art. $14^{\circ}$ apresenta as circunstâncias atenuantes da pena, entre elas o arrependimento do infrator, pela reparação espontânea ou limitação significativa do dano causado, a comunicação prévia de risco iminente de degradação ambiental, e a colaboração com os agentes encarregados da vigilância e do controle ambiental.

$\mathrm{O}$ art. $15^{\circ}$, por sua vez, relaciona as circunstâncias agravantes, entre elas a reincidência no crime, e o fato de a infração ter sido cometida:

- para obter vantagem econômica;

- por meio de coação, fraude ou abuso de confiança;

- afetando ou expondo a grave perigo a saúde pública ou o meio ambiente;

- atingindo regiões, como áreas urbanas ou quaisquer assentamentos humanos, e espaços territoriais especialmente protegidos;

- em determinados dias ou épocas do ano - domingos ou feriados; à noite; em secas ou inundações;

- no interesse de pessoa jurídica que receba verbas públicas ou incentivos fiscais;

- facilitada por funcionário público em exercício de função. 
O Capítulo V da Lei discorre sobre os crimes contra o meio ambiente, dividindoos em crimes contra a fauna (art. $33^{\circ}$ ), contra a flora (art. $44^{\circ}$ ) e crimes ambientais (art. $54^{\circ}$ ). Mais especificamente, no caso das indústrias, são considerados crimes ambientais:

- a produção, o processamento, a embalagem, a importação, a exportação, o comércio, o fornecimento, o transporte, a armazenagem ou utilização de produto ou substância tóxica, perigosa ou nociva à saúde humana ou ao meio ambiente, em desacordo com leis ou regulamentos. $\mathrm{O}$ abandono de produtos ou substâncias também é punível (art. 56);

- a construção, reforma, ampliação, instalação ou funcionamento no território brasileiro de qualquer estabelecimento, obra ou serviço potencialmente poluidor, sem licença ou autorização, ou em desacordo com as normas legais e regulamentares pertinentes (art. 60).

Fritsch (2000) destaca que na legislação anteriormente existente, adotava-se o princípio poluidor/pagador; isto é, o simples pagamento eximia o poluidor de quaisquer outras obrigações em relação ao meio ambiente. A partir desta lei, não é mais suficiente que o infrator pague pelos danos causados ou recupere a degradação que provocou, uma vez que está também sujeito a penas de outra natureza, como a detenção e a interdição temporária de direito.

\subsubsection{Resoluções CONAMA}

O CONAMA é o órgão deliberativo-consultivo do Sistema Nacional do Meio Ambiente. Em outras palavras, tem, segundo o texto da Lei 6938/81, a finalidade de “assessorar, estudar e propor ao Conselho do governo diretrizes de políticas governamentais para o meio ambiente e os recursos naturais e deliberar, no âmbito de sua competência, sobre normas e padrões compatíveis com o meio ambiente ecologicamente equilibrado e essencial à sadia qualidade de vida". Nesse sentido, as resoluções elaboradas pelo CONAMA complementam as leis federais, detalhando-as. Alguns exemplos significativos são:

\section{$\underline{\text { Resolução } \mathrm{n}^{\circ} \text { 001, de } 23 \text { de janeiro de } 1986}$}

Estabelece diretrizes gerais para a implementação do processo de Avaliação de Impacto Ambiental (AIA), e apresenta uma relação de empreendimentos cujo licenciamento depende da realização do chamado Estudo de Impacto Ambiental (EIA) e do respectivo Relatório de Impacto Ambiental (Rima). O EIA deve, entre outros 
requisitos, identificar e avaliar sistematicamente os impactos ambientais gerados tanto na fase de implantação como durante a operação da atividade.

Resolução no 313 , de 29 de outubro de 2002

Dispõe sobre o Inventário Nacional de Resíduos Sólidos Industriais. Segundo a lei, o Inventário é o conjunto de informações sobre a geração, características, armazenamento, transporte, tratamento, reutilização, reciclagem, recuperação e disposição final dos resíduos sólidos gerados pelas indústrias do país. Visa compensar a falta de informações mais detalhadas sobre a geração e formas de tratamento e destinação dos resíduos gerados em indústrias, entre os quais se inserem os resíduos de embalagens de uso industrial.

A resolução transforma o controle dos resíduos existentes ou gerados pelas atividades industriais, em parte integrante do seu processo de licenciamento ambiental, isto é, condiciona a obtenção da licença de funcionamento à existência do inventário, o que, em tese, obriga as indústrias a manter registros atualizados dos resíduos sólidos nelas gerados. As indústrias devem apresentar ao órgão estadual de meio ambiente informações sobre geração, características e forma de gerenciamento de seus resíduos sólidos (ver Quadro 5). O texto inclui um modelo de formulário a ser preenchido pela indústria para a coleta desses dados. Nele, é apresentada uma série de códigos para classificar os resíduos encontrados na indústria e as formas de armazenamento, tratamento, reciclagem e disposição final utilizadas. São classificáveis resíduos como embalagens metálicas e de metais não ferrosos (latas vazias), tambores metálicos, bombonas de plástico não contaminadas, filmes e pequenas embalagens de plástico, resíduos de acetato de etil vinila (EVA) e de poliuretano (PU), espumas, e mesmo resíduos de embalagens gerados fora do processo industrial, em setores como escritórios (ver Quadro 6). 
Quadro 5 - Principais dados a serem coletados para o Inventário

\section{Informações gerais da indústria}

- Razão social da indústria, endereço da planta industrial, endereço para correspondência, contato técnico (responsável).

\section{Características da atividade industrial}

- atividade principal da indústria;

- período de produção: horas por dia, dias por mês, meses por ano;

- número de funcionários em cada setor da indústria: Produção, Administração, outros;

- área útil total, em $\mathrm{m}^{2}$

- coordenadas geográficas da planta: latitude e longitude, em graus e minutos.

\section{Processo de produção desenvolvido pela indústria}

- matérias-primas e insumos ${ }^{6}$ utilizados: quantidade atual (por ano), capacidade máxima (por ano), com respectivas unidades de medida;

- produção anual da indústria: produtos, quantidade atual (por ano), capacidade máxima (por ano), com respectivas unidades de medida;

- relação das etapas do processo industrial, com a respectiva descrição e os pontos de geração de resíduos sólidos - uma para cada linha de produção existente.

\section{Resíduos sólidos gerados nos últimos doze meses}

- descrição do resíduo;

- formas de armazenamento e tratamento (dentro ou fora da indústria) e métodos de destinação final para cada tipo de resíduo gerado nos últimos doze meses.

\section{Resíduos sólidos gerados nos anos anteriores}

Para cada tipo de resíduo sob a responsabilidade da empresa:

- descrição do resíduo e da respectiva forma de armazenamento, seja ele feito na área da própria indústria ou não;

- se o armazenamento ocorre em uma área fora da indústria: posição geográfica desse local, em graus e minutos;

- quantidade / ano, em toneladas dos últimos doze meses;

- estado físico: sólido, gases, semi-sólido ou pastoso, ou líquido.

Fonte: CONAMA (2003)

\footnotetext{
${ }^{6}$ Matéria-prima: substância principal e essencial na composição de um produto, submetida a processo de beneficiamento ou transformação, para a obtenção deste produto. Ex.: aço, cana-de-açúcar, peles. Insumo: toda substância que faz parte do processo produtivo, beneficiando ou transformando a matéria-prima. Ex.: produtos químicos, detergentes. (definições existentes na Resolução)
} 
Quadro 6 - Métodos de gerenciamento de resíduos - exemplos de classificação

Método de armazenamento:

Resíduos atualmente gerados (S):

S01 - tambor em piso impermeável, área coberta

S02 - a granel em piso impermeável, área coberta

S03 - caçamba com cobertura

S11 - tambor em piso impermeável, área descoberta

S12 - a granel em piso impermeável, área descoberta

S13 - caçamba sem cobertura

S21 - tambor em solo, área coberta

S31 - tambor em solo, área descoberta

(no caso de resíduos não mais gerados, substitui-se o $\mathrm{S}$ por $\mathrm{Z}$ )

Método de tratamento:

T01 - Incinerador

T05 - Queima a céu aberto

T08 - Encapsulamento / fixação química ou solidificação

T17 - Secagem

T19 - Plasma térmico

Processos de reutilização / reciclagem / recuperação:

R01 - Utilização em forno industrial (exceto em fornos de cimento)

R02 - Utilização em caldeira

R06 - Incorporação em solo agrícola

R12 - Sucateiros intermediários

R13 - Reutilização / reciclagem / recuperação internas

Método de disposição final:

B02 - Aterro municipal

B03 - Aterro industrial próprio

B04 - Aterro industrial - terceiros

B05 - Lixão municipal

B06 - Lixão particular

Fonte: CONAMA (2003)

É preciso observar que, no momento, a classificação de resíduos constante na resolução CONAMA 313/02 encontra-se desatualizada, por ter sido elaborada com base no texto antigo da norma NBR 10004 (classificação de resíduos sólidos). A resolução, por exemplo, determina códigos para embalagens consideradas "resíduos nãoperigosos", fazendo menção às classes II e III, divisão abandonada na nova redação da norma. No final de 2004, foram editadas novas versões das normas NBR 10004 a 10007, mas até o presente momento, ainda não havia previsão de alterações na resolução para adaptá-la aos novos textos (SESANA, 2005). 


\subsubsection{A Política Nacional de Resíduos Sólidos}

Em maio de 2002, foi enviado ao Congresso Nacional o substitutivo do Projeto de Lei $n^{\circ} 203$, de 1991. Este projeto, entre outras providências, institui a Política Nacional de Gerenciamento de Resíduos Sólidos e estabelece diretrizes e normas para o "gerenciamento compartilhado, descentralizado e participativo dos diferentes tipos de resíduos sólidos".

Na subseção II ("dos resíduos industriais e de mineração"), o projeto de lei atribuía, no artigo 45, aos estabelecimentos industriais e de mineração a responsabilidade pelo gerenciamento completo de seus resíduos, desde a sua geração até a destinação final, incluindo:

- separação e coleta interna diária dos resíduos;

- acondicionamento, identificação e transporte interno;

- manutenção de áreas para operação e armazenagem de resíduos;

- apresentação dos resíduos à coleta externa;

- transporte externo, tratamento e destinação final dos resíduos.

Os responsáveis pelos estabelecimentos industriais ou de mineração, conforme o artigo 46, arcariam com os custos relativos a todas as etapas do gerenciamento de seus resíduos, incluídas as análises técnicas requeridas pelos órgãos competentes. No entanto, segundo Campanili (2002), a indústria conseguiu garantir que, no projeto de lei, a responsabilidade pós-consumo seja compartilhada entre o poder público, o setor produtivo e o consumidor.

A Subseção XII (“das embalagens”) apresenta definição e classificações das embalagens (art. 102). Importante distinção faz o parágrafo $3^{\circ}$ do artigo, ao explicitar que "os resíduos de embalagens não abrangem os resíduos de produção".

O artigo 103 determina prazo máximo de dois anos, a contar da data de entrada em vigor da lei, para que as embalagens, entre outros requisitos, sejam concebidas, produzidas e comercializadas de forma a permitir a sua reutilização, valorização ${ }^{7}$, ou reciclagem e a minimizar o impacto sobre o meio ambiente. Nota-se, aqui, a clara influência do texto da Diretiva 94/62 da Comunidade Européia, que estabeleceu condições semelhantes para a fabricação de embalagens em seus países-membros.

\footnotetext{
${ }^{7}$ Segundo o parágrafo único do art. 117 do projeto de lei, as embalagens devem ser valorizáveis sob a forma de reciclagem, de valorização energética, ou tratadas para fins de compostagem.
} 
Os órgãos competentes do SISNAMA promoverão, segundo o artigo 104, a elaboração de normas técnicas relativas a aspectos como:

- critérios e metodologias de análise do ciclo de vida da embalagem;

- critérios referentes à existência de um teor mínimo de material reciclado nas embalagens;

- critérios a serem adotados quanto aos métodos de reciclagem, compostagem e à marcação das embalagens.

O fabricante ou importador e o utilizador ou envasador de embalagem terão como obrigações a elaboração anual de Plano de Gestão de Resíduos Especiais de Embalagens, nos moldes determinados pela lei (art. 108), e o recebimento, em retorno, embalagens ou resíduos de embalagens por eles fabricados ou utilizados, desde que isentas de contaminação (art. 109).

Os fabricantes ou importadores de embalagens devem, ainda, criar sistemas que garantam a coleta e recuperação de embalagens e resíduos visando a destinação adequada, "nos termos desta lei", bem como a reutilização e a valorização, incluindo a reciclagem (art. 110). Caso tais sistemas sejam implantados, o art. 111 determina que os distribuidores e os pontos de venda ficam obrigados a receber, também em depósito, essas embalagens ou resíduos.

O artigo 112 estipula prazo de um ano, a partir da data de vigência da lei, para que os utilizadores ou envasadores, distribuidores, pontos de venda e, em especial, os consumidores de embalagens disponham de informações sobre:

- sistemas existentes para recuperação, coleta e valorização da embalagem;

- possibilidades de contribuição para reutilização, valorização e reciclagem da embalagem e resíduos de embalagens; e

- o significado das marcações nas embalagens existentes no mercado.

$\mathrm{O}$ art. 113 também determina prazo de um ano para que as embalagens fabricadas passem a indicar a origem dos materiais utilizados em sua produção.

Em seu artigo 114, o projeto de lei prevê, ainda, o estabelecimento de metas mínimas de reciclagem de embalagens, a serem observadas pelos fabricantes e pelos utilizadores ou envasadores de embalagens de bebidas, alimentos, demais descartáveis plásticos, metálicos, de papel e de vidro.

Por fim, segundo o texto, Os Estados, Municípios e o Distrito Federal deverão incentivar: 
- o uso de sistemas de reutilização das embalagens em moldes que respeitem o ambiente e as normas de saúde pública (art. 118);

- o uso de materiais provenientes de resíduos de embalagens reciclados para o fabrico de embalagens e outros produtos (art. 119);

- o estabelecimento de programas de ação nacional, estadual, municipal, distrital ou regional.

\subsection{Conclusões - sinais do descompasso entre o Brasil e o exterior}

Depois da leitura e análise das leis apresentadas, percebe-se que a atual legislação brasileira, mesmo sendo bastante abrangente, ainda não contemplou de forma adequada a questão dos resíduos de embalagens de uso industrial. Dispõe-se de parâmetros para classificação destes resíduos na resolução CONAMA 313/02, porém o aspecto do gerenciamento propriamente dito ainda permanece fora dos dispositivos legais. A única exceção é o gerenciamento dos resíduos de embalagens de agrotóxicos, regulamentado pela Lei 7802/89, modificada pela Lei 9974/00, e pela resolução CONAMA 334 de 2003; nenhum destes dispositivos, porém, se aplica ao caso da presente pesquisa.

A partir da comparação com a União Européia, observa-se que o Brasil, em termos de arcabouço legal, está atrás não apenas de alguns países isolados, mas de todo um bloco de países que tem grande participação e importância nas relações comerciais e no cenário político mundial. A propósito, autores como Almeida (1998) apontam como principal característica dos instrumentos da política ambiental brasileira o seu caráter corretivo, e não preventivo. Tais instrumentos são definidos como sendo de "comando e controle", isto é, determinam o que fazer e fiscalizam o cumprimento. Em função disso - do aspecto do "controle" -, dependem de fiscalização intensa para funcionar adequadamente, o que requer mão-de-obra preparada. Assim, segundo a autora, há grande dependência de recursos públicos para executar as ações de regulação; conseqüentemente, as agências ambientais estaduais e demais órgãos encarregados da fiscalização têm dificuldade em monitorar as condições ambientais, o que só consegue ser realizado nos grandes centros.

Diante desta situação, a Política Nacional de Resíduos Sólidos, cujo projeto de lei apresenta disposições relativas às embalagens visivelmente influenciadas pela 
diretiva 94/62 da União Européia, constitui uma tentativa de diminuir o atraso do país na matéria. A aprovação do texto pode significar a existência, no Brasil, de um instrumento de suporte legal ao estabelecimento de sistemas de gerenciamento que privilegiem a prevenção da poluição, abandonando os tratamentos de "fim de tubo". Ainda assim, haverá necessidade de uma fiscalização eficiente para observar o cumprimento das metas e normas e o funcionamento dos sistemas eventualmente criados por força daquela lei.

Evidentemente, não se pode prescindir de dispositivos como normas e selos de qualidade, cuja conquista constitui estímulo muitas vezes mais significativo para uma empresa. A busca pelos benefícios advindos de certificações, como a melhora na imagem da empresa e a possibilidade de conquistar novos mercados - inclusive em outros países - leva a mudanças de mentalidade que, ainda que involuntariamente, podem conduzir à utilização mais racional de recursos naturais. 


\section{METODOLOGIA}

\section{Histórico e definição do universo de pesquisa}

O método para pesquisa foi desenvolvido e aperfeiçoado ao longo do curso, em razão de não ter sido encontrada pesquisa nem metodologia semelhante na bibliografia consultada. De início, foi determinado que o universo de pesquisa seria composto por indústrias da cidade de São Carlos. Isto porque o parque industrial da cidade, além de significativo qualitativa e quantitativamente, oferece a vantagem da proximidade, o que deveria em tese facilitar o contato com as indústrias. Ao longo do desenvolvimento da pesquisa, em especial por ocasião das etapas de qualificação, foram apresentadas várias sugestões, entre as quais a idéia de focar a pesquisa nas empresas montadoras localizadas na cidade. Esta escolha pareceu bastante lógica, uma vez que a atividade de montagem envolve o recebimento de inúmeras partes e componentes; assim, ainda que tais empresas contem com linhas de fabricação de peças, dependem principalmente do recebimento de lotes de componentes, o que conseqüentemente leva ao recebimento de grandes quantidades de embalagens de diversos tipos.

Por essa época, a proposta de estudo comparativo de duas ou mais empresas foi substituída pela realização de um estudo de caso simples, em razão de limitações de tempo e pessoal necessárias para conduzir uma comparação de forma realmente aprofundada. Assim, definiu-se a metodologia empregada na parte prática da pesquisa: um estudo de caso simples a ser realizado em uma empresa montadora instalada em São Carlos.

O próximo passo da pesquisa consistiu em identificar e elaborar uma lista das principais empresas montadoras localizadas na cidade e estabelecer os contatos iniciais. A Volkswagen Fábrica de Motores a primeira das empresas contatadas a concordar em participar da pesquisa. Foi enviada, então, à empresa, uma solicitação de visitas; após o aceite, deu-se início à parte prática propriamente dita da pesquisa.

\section{$\underline{\text { Seqüência lógica do estudo }}$}

O estudo adotou a seguinte seqüência lógica para obter os dados:

Empresa $\rightarrow$ Linha $\rightarrow$ Produto $\rightarrow$ Componentes $\rightarrow$ Embalagens 
Ao longo dessa seqüência, várias informações foram sendo obtidas de modo a situar a questão dos resíduos de embalagens na empresa. $\mathrm{O}$ estudo não se restringiu à análise das embalagens e de seus resíduos, mas também procurou reunir informações relativas a aspectos periféricos, como será detalhado a seguir. Assim, com a metodologia adotada, foram coletados tanto dados diretos - referentes ao produto adotado para análise - como indiretos, referentes às atividades outros setores da empresa, como a Logística e Segurança do Trabalho.

\section{Coleta de dados - as visitas}

As visitas técnicas à planta foram realizadas periodicamente, e incluíram entrevistas com representantes de diversos setores da empresa. As entrevistas foram sendo agendadas uma a uma, por telefone ou mensagens de correio eletrônico, e realizadas conforme a disponibilidade dos representantes. A troca de mensagens pela Internet também possibilitou a coleta de dados, quando a realização de visitas não era possível.

Foram visitados os setores de Recursos Humanos, Qualidade e Logística, bem como o pátio externo de resíduos, além, evidentemente, da linha escolhida para a pesquisa.

De modo geral, os únicos entraves à realização da pesquisa foram a dificuldade no agendamento de visitas e a ocasional necessidade de reagendamento. Estas situações já eram esperadas desde o início da pesquisa, visto que a dinâmica de uma empresa muitas vezes dificulta o contato e a disponibilidade deste ou daquele funcionário.

\section{Os dados obtidos}

Dentre os modelos de motores fabricados pela empresa, foi adotado para a análise o motor 1.0, a gasolina. Essa escolha é explicada pelo fato de que os carros com motor 1.0 tem presença majoritária no mercado brasileiro, com 52,83\% de participação, segundo dados da Federação Nacional de Distribuição de Veículos (Fenabrave), relativos a 2004 (VENDA DE CARROS..., 2005). Em função dessa escolha, foi aplicado um questionário, previamente elaborado, para auxiliar na obtenção e reunião das informações. A versão final do questionário encontra-se no Anexo I.

Durante as visitas, o questionário foi “desmembrado", isto é, proposto em partes a cada representante de setor, de modo que em cada caso fossem dirigidas as questões 
mais convenientes, ou que pudessem ser melhor respondidas por aquele contato em particular.

Uma vez que a pesquisa consistiu em estudo simples de caso, não houve a necessidade de estabelecer comparação direta com outra empresa da cidade, por meio de uma base comum de informações a serem coletadas. Ao mesmo tempo, visitas preliminares permitiram um contato inicial com a organização da planta, e com as particularidades de seu processo de produção. Estes dois fatores permitiram que o questionário preparado inicialmente fosse revisto para se amoldar à realidade da empresa. Assim, algumas perguntas foram retiradas, por se mostrarem desnecessárias, ou cederam destaque no questionário; houve o acréscimo de questões e $\mathrm{o}$ desenvolvimento de outras. De modo geral, os aspectos logísticos do processo produtivo, como a relação com os fornecedores da empresa, ganharam importância no estudo. É evidente que, caso não se soubesse de maiores informações sobre o tipo de embalagens utilizadas, teria sido utilizado um questionário mais geral.

As questões diretamente relacionadas à linha de produção e às embalagens envolvidas foram direcionadas a representantes do setor de Qualidade da empresa. Foi possível ter acesso a documentos como a relação de componentes envolvidos na fabricação de cada tipo de motor, chamada de Austaktung, diagramas da linha de produção do motor em questão, e o manual de embalagens, que relaciona todos os tipos de embalagens utilizados na planta, com fotos, informações sobre a capacidade de cada um e os componentes que podem conter. Foram obtidos, ainda, dados complementares diretamente com um dos representantes da empresa, sobre os fornecedores de cada componente e sua cidade ou país de origem.

Obteve-se como resultado uma planilha com dados sobre os componentes do motor em questão, bem como as correspondentes embalagens, empresas e locais de procedência e a ocorrência ou não de geração de resíduo derivado da embalagem.

Inicialmente, a intenção era recolher todos os resíduos de embalagem gerados à medida que ocorria a produção do motor escolhido. Isto, porém, não foi possível, porque a linha de produção da planta opera em lotes: em um dado momento, era possível notar que no meio da linha estava sendo fabricado um certo tipo de motor, e no início da linha era fabricado outro tipo. Portanto, além de ser necessário saber de antemão qual motor seria fabricado em certo dia - e ainda assim, poderia haver mudanças de última hora, para atender alguma encomenda - seria preciso identificar e separar os resíduos gerados pelas embalagens correspondentes ao motor escolhido, e o 
nível de padronização observado nas embalagens poderia induzir a vários erros nessa análise. Dessa forma, tal abordagem não foi adotada, o que impossibilitou a obtenção, nesta pesquisa, de indicadores como a quantidade de resíduo gerado (em $\mathrm{Kg}$ ) por unidade de motor. Foi possível, no entanto, realizar estimativas desta quantidade a partir de dados constantes do balanço geral de resíduos mantido pela planta.

Adicionalmente, a simples observação da linha e dos setores visitados permitiu a obtenção de dados, como previsto. Foi possível registrar algumas dessas informações por meio de fotografias.

Por fim, ainda a respeito do questionário, deve-se salientar também que ele foi inteiramente desenvolvido durante o curso, com uma única exceção: a seção em forma de tabela, que procura identificar aspectos na relação com fornecedores da empresa, foi extraída de um questionário proposto por um grupo formado por professores e alunos do Departamento de Engenharia de Produção da Escola Politécnica da USP. Esse questionário foi utilizado por ocasião de uma pesquisa encomendada pelo BNDES e iniciada pelo grupo em 2001, com o objetivo de avaliar a cadeia de suprimentos na indústria automobilística brasileira ${ }^{8}$.

\footnotetext{
${ }^{8}$ Projeto contratado pelo BNDES através da Fundação Carlos Alberto Vanzolini; mais informações no site http://www.prd.usp.br/cadeia-automotiva/
} 


\section{RESULTADOS E DISCUSSÕES}

A fábrica de motores da Volkswagen, de São Carlos (SP), está localizada à Rodovia Luís Augusto de Oliveira (SP-215), km 148,8, próxima a um dos trevos de acesso a cidade. Inaugurada em 12 de outubro de 1996, tem área total de $7.500 .000 \mathrm{~m}^{2} \mathrm{e}$ área construída de $35.000 \mathrm{~m}^{2}$. Emprega atualmente 535 funcionários, sendo que 305 deles diretamente envolvidos na produção.

A planta conta com duas linhas de produção:

- linha EA-111: conta com 285 funcionários, realizando operações de usinagem e montagem. Fabrica toda a linha de motores 1.0, para os modelos Gol, Polo, Fox e Parati, motores 1.6 para os modelos Polo, Golf e Fox, além dos motores 1.4; parte destes equipa a Kombi, e parte é exportada para a África do Sul e Europa.

- linha EA-113: conta com 20 funcionários, no turno da manhã, atuando em operações de montagem final. Fabrica motores de veículos mais sofisticados e dirigidos à exportação.

Os funcionários terceirizados atuando dentro da planta somam 335 pessoas, em áreas como logística, afiação de ferramentas e lubrificação. Desse total, 175 são da SG Logística, empresa responsável pela execução da logística definida pela VW.

\subsection{As embalagens}

Observou-se, logo de início, a utilização maciça de embalagens retornáveis. Segundo os representantes da empresa, esta é a prática em vigor na planta desde o início de seu funcionamento, o que reflete certas particularidades da fábrica de São Carlos, já que outras plantas da companhia, como a própria Matriz brasileira da empresa, em São Bernardo do Campo (SP), só vieram a adotar essa política após algum tempo já em operação.

A planta obteve recentemente a certificação de seu Sistema de Gestão Ambiental pela norma ISO 14001:2004, a nova versão da ISO 14001 editada no final de 2004. Segue, ainda, princípios estabelecidos na norma alemã VDA 6.3, relativa à indústria automobilística, e que, entre outras disposições, determina os tipos de embalagens a serem utilizados pelas indústrias do ramo.

As embalagens encontradas na linha analisada são de 3 tipos básicos: 
- KLT: em 3 tamanhos básicos, para peças de pequeno porte

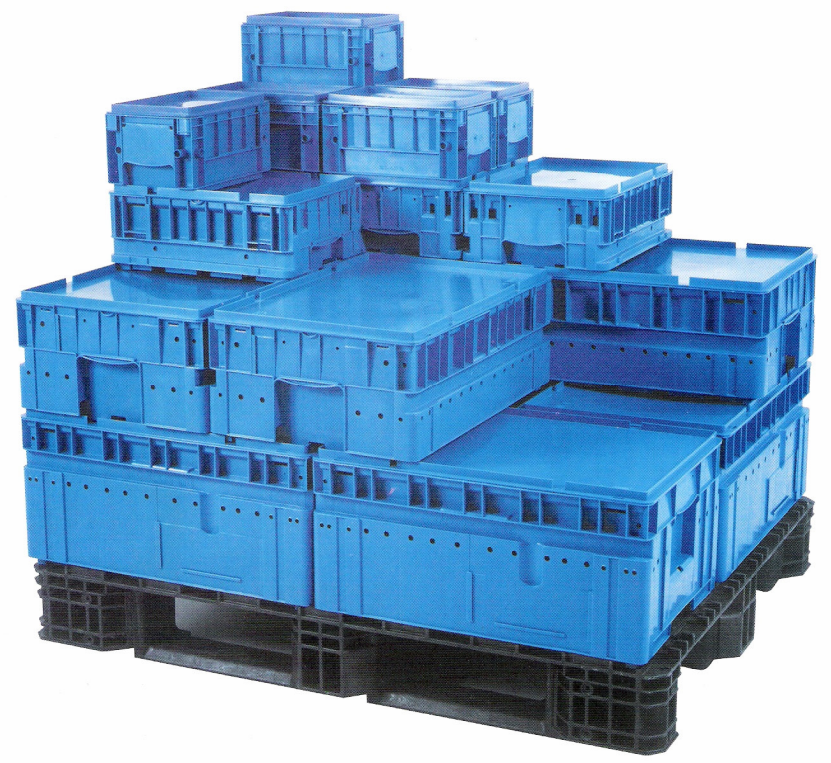

Figura 11 - Caixas KLT em 5 tamanhos diferentes, sobre palete plástico (Unipac, 2002)

- Caixamóbil: para peças maiores, mas que podem ser colocadas juntas, em contato umas com as outras; pode ser disposta junto à linha de produção e mantida aberta, para acesso rápido às peças; é também colapsível, o que facilita e reduz os custos de seu transporte quando vazia.
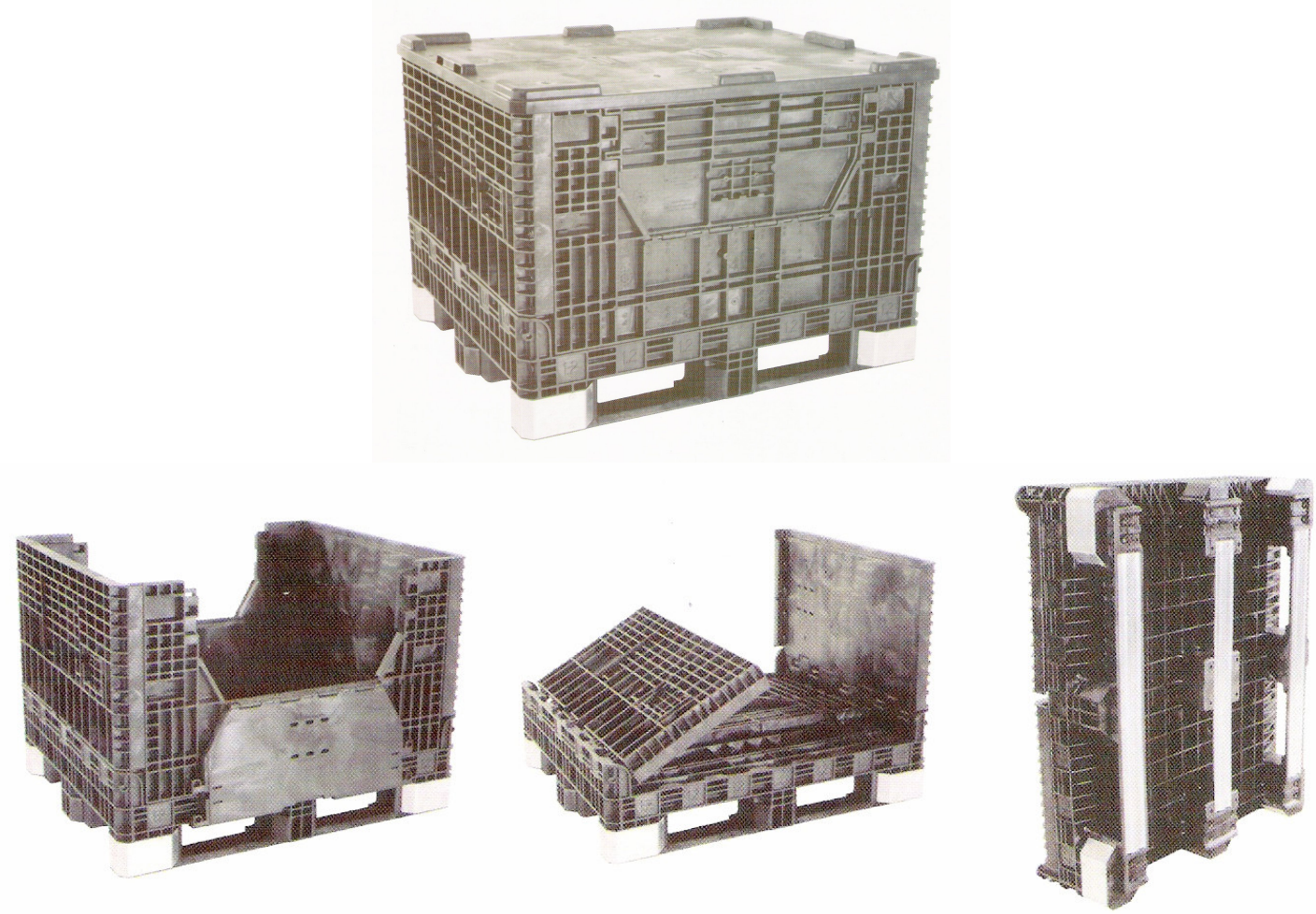

Figura 12 - Caixamóbil (Unipac, 2001) 
- Vacuum forming: Dispositivos que englobam tanto paletes e tampas, quanto berços plásticos, nos quais os componentes podem ser encaixados e fixados durante o transporte e armazenamento.

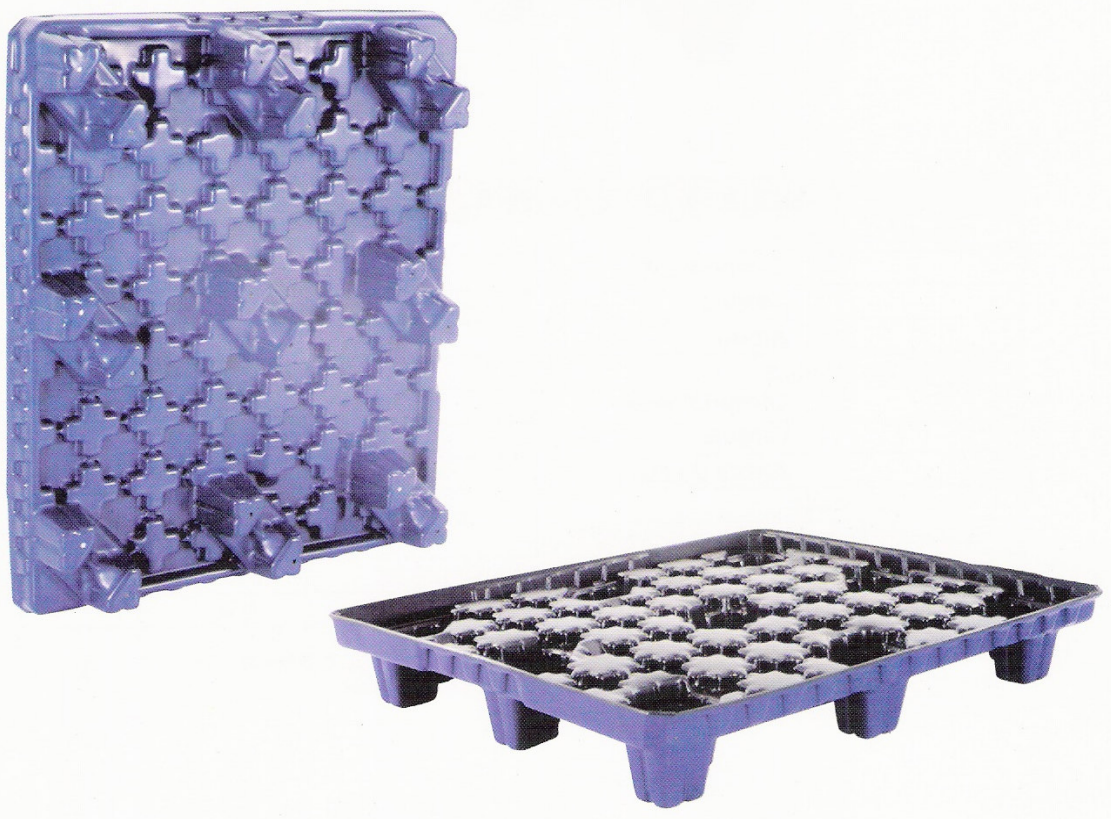

Figura 13 - Palete vacuum-forming (Unipac, 2000)

As embalagens retornáveis observadas na empresa traziam sempre impressos os nomes da empresa fornecedora das peças e da Volkswagen, como mostra o exemplo a seguir. Isto porque, por contrato, as embalagens são de uso e trânsito exclusivo entre a VW e seus fornecedores. Como tais tipos de embalagens padronizadas são também adotados por outras empresas do setor, a existência de identificação, na embalagem, das empresas que a utilizam evita extravios e trocas involuntárias.

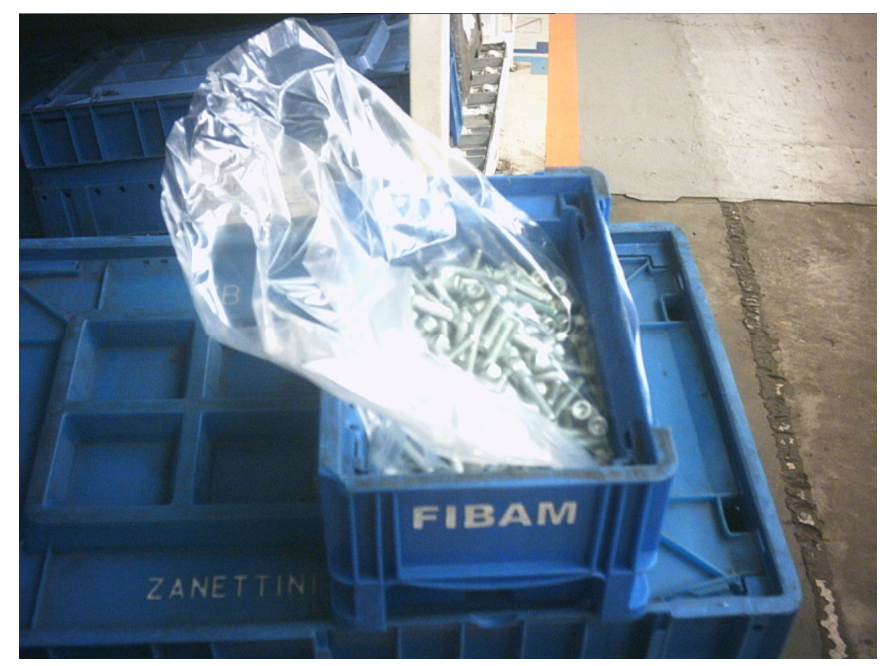

Foto 1 - Caixa KLT2001, de uso exclusivo entre a empresa (Fibam) e a Volkswagen 
As embalagens também recebem etiquetas com informações como:

- Nome e quantidade do componente contido na embalagem;

- Nome da empresa fornecedora;

- Pesos líquido, relativo ao peso dos componentes, e bruto, em $\mathrm{Kg}$;

- Tipo da embalagem;

- Data de expedição.

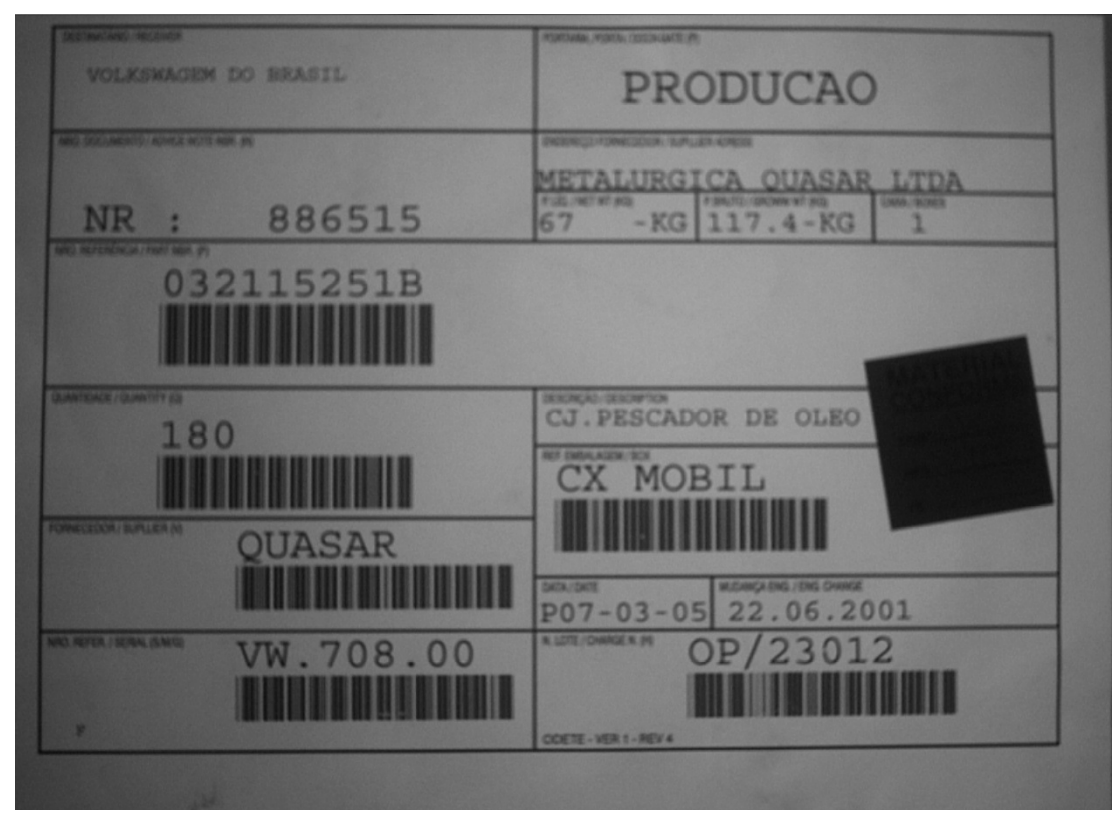

Foto 2 - Exemplo de etiqueta aplicada às embalagens

\subsection{Os acessórios}

Uma presença marcante nas embalagens observadas na linha é a presença dos chamados "acessórios", que visam à proteção dos componentes durante o transporte e armazenamento, bem como à manutenção da limpeza e lubrificação de certas peças, quando necessário. Os principais tipos de acessórios encontrados nas embalagens analisadas estão descritos a seguir.

- sacos plásticos: em polietileno de baixa densidade; acondicionam peças pequenas e numerosas, como parafusos, no interior das caixas KLT, impedindo contaminação por partículas de poeira no ar. 


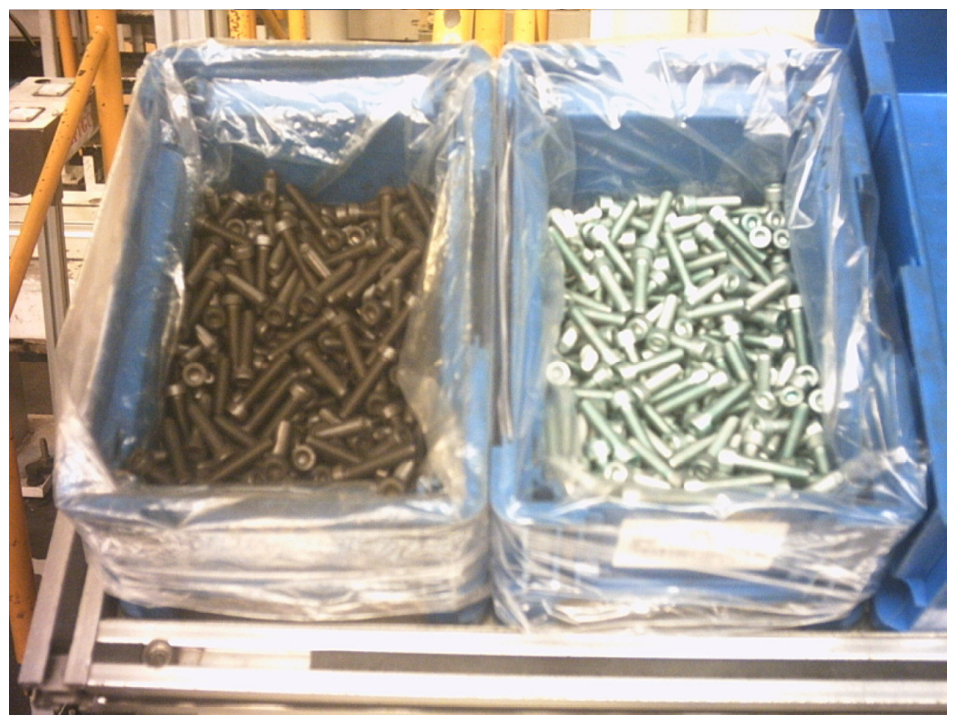

Foto 3 - Caixas KLT 2001, contendo parafusos protegidos por saco plástico

- Sacos de VCI: para peças maiores; são sacos de polietileno, em geral na cor amarela, que contêm sais orgânicos que se volatilizam gradualmente, gerando o chamado VCI (vapor inibidor de corrosão) e se depositando sobre os componentes. Esta camada substitui o óleo e a sílica como anticorrosivo, e se dissipa imediatamente ao se abrir a embalagem (Jornal de Plásticos, 2005; VCI Brasil, 2005).

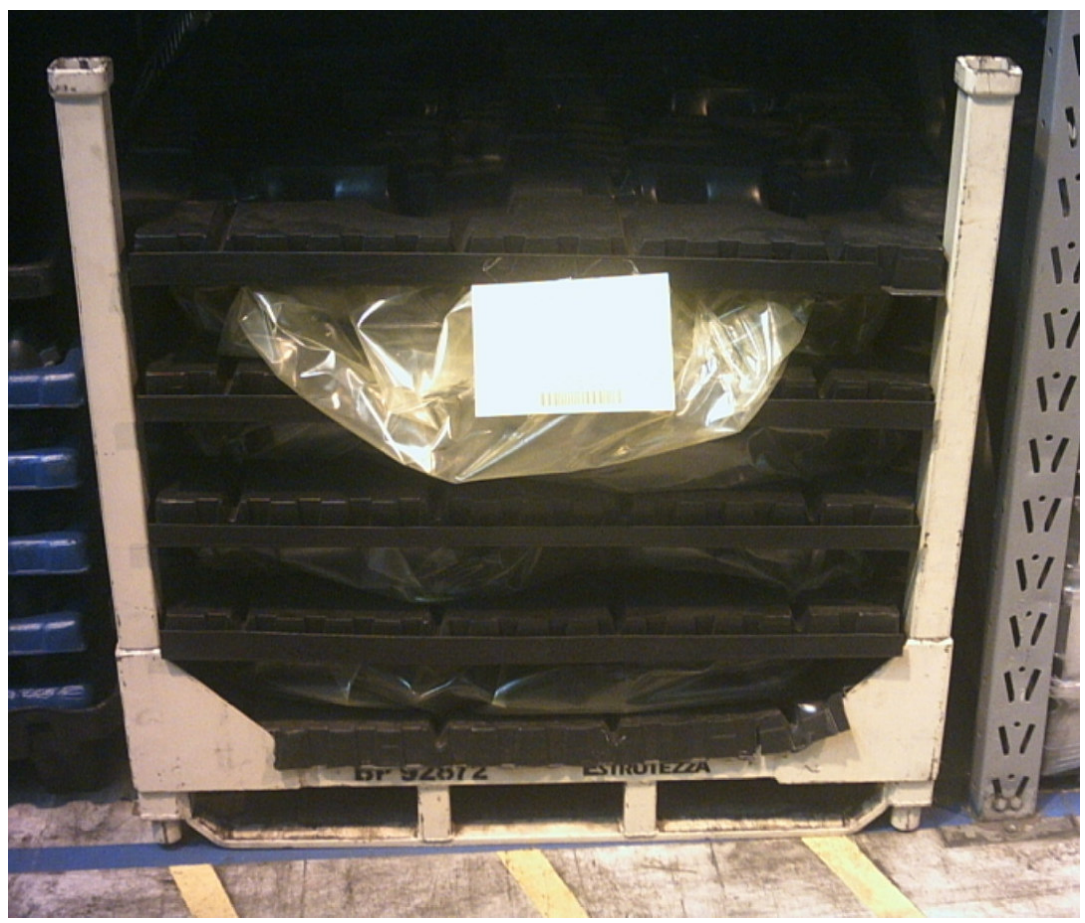

Foto 4 - Rack metálico, recipientes vacuum-forming e componentes em sacos de VCI 
- plástico bolha: protege componentes como blocos de motores:

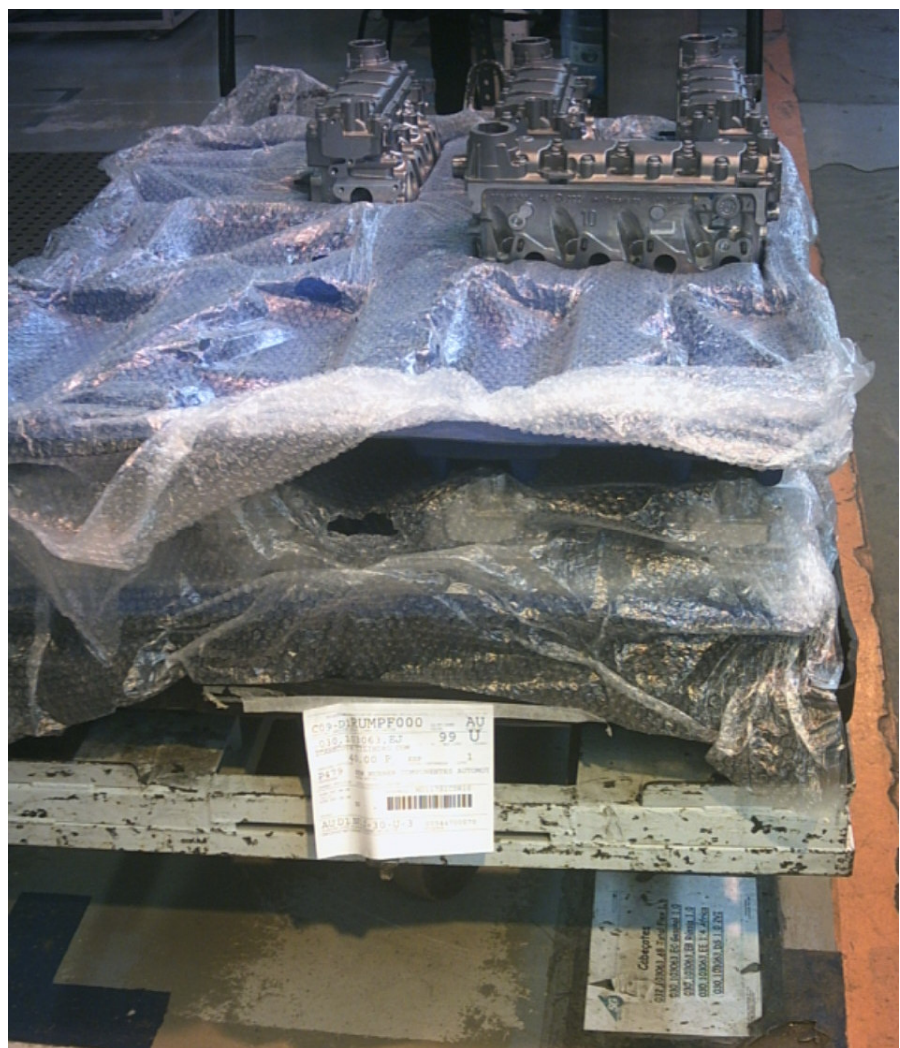

Foto 5 - Blocos de motor sobre berço plástico com manta de plástico bolha

- cintas plásticas: para garantir o fechamento da embalagem

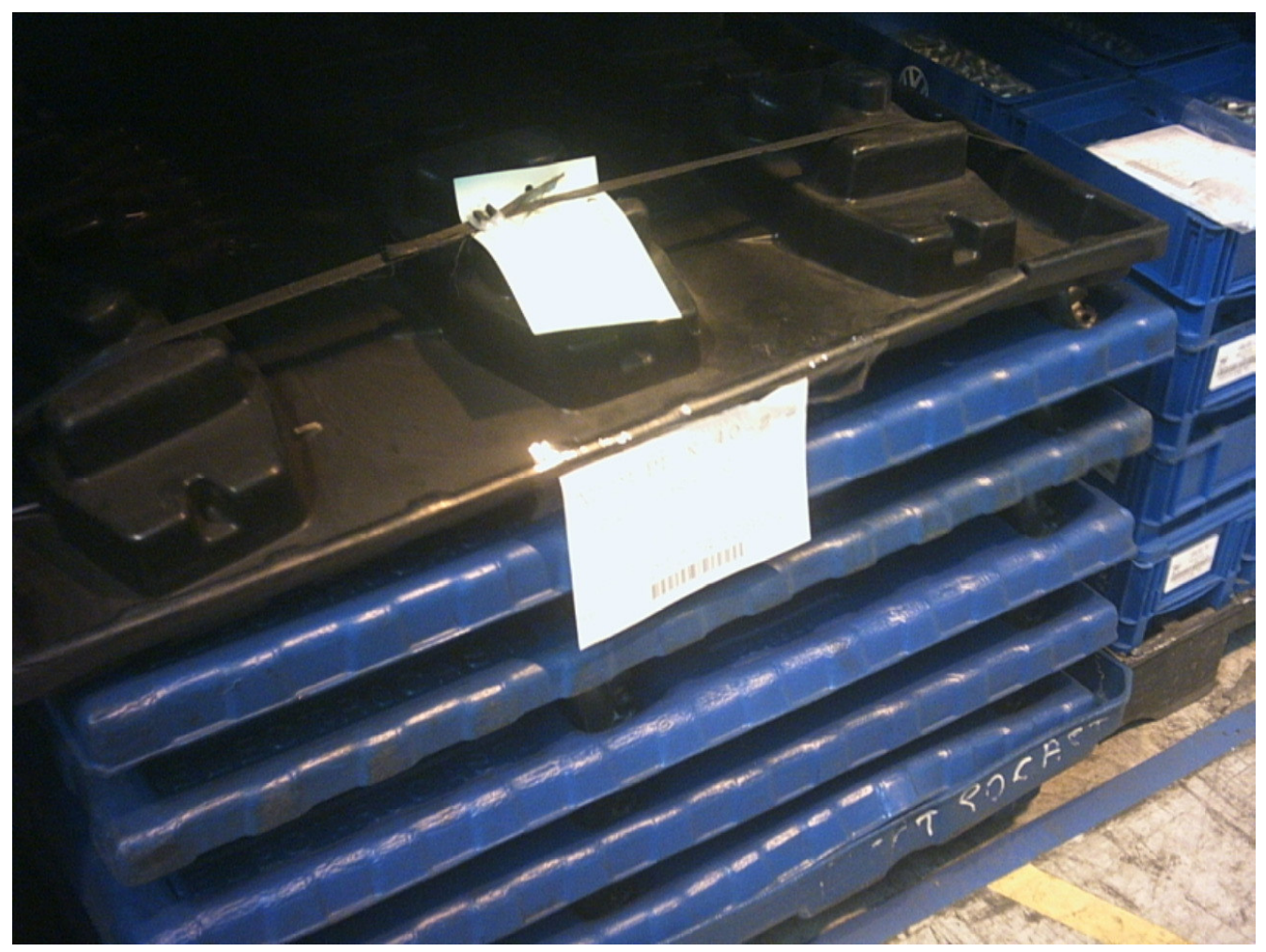

Foto 6 - Conjunto (berços plásticos e tampa vacuum-forming) fixado por cinta plástica 
- separadores de polionda: de estrutura semelhante ao papelão ondulado, porém em plástico, a polionda é utilizada nas formas "placa", que separa camadas de peças dentro da caixa, e "grade", que separa as peças como em um engradado de bebidas.

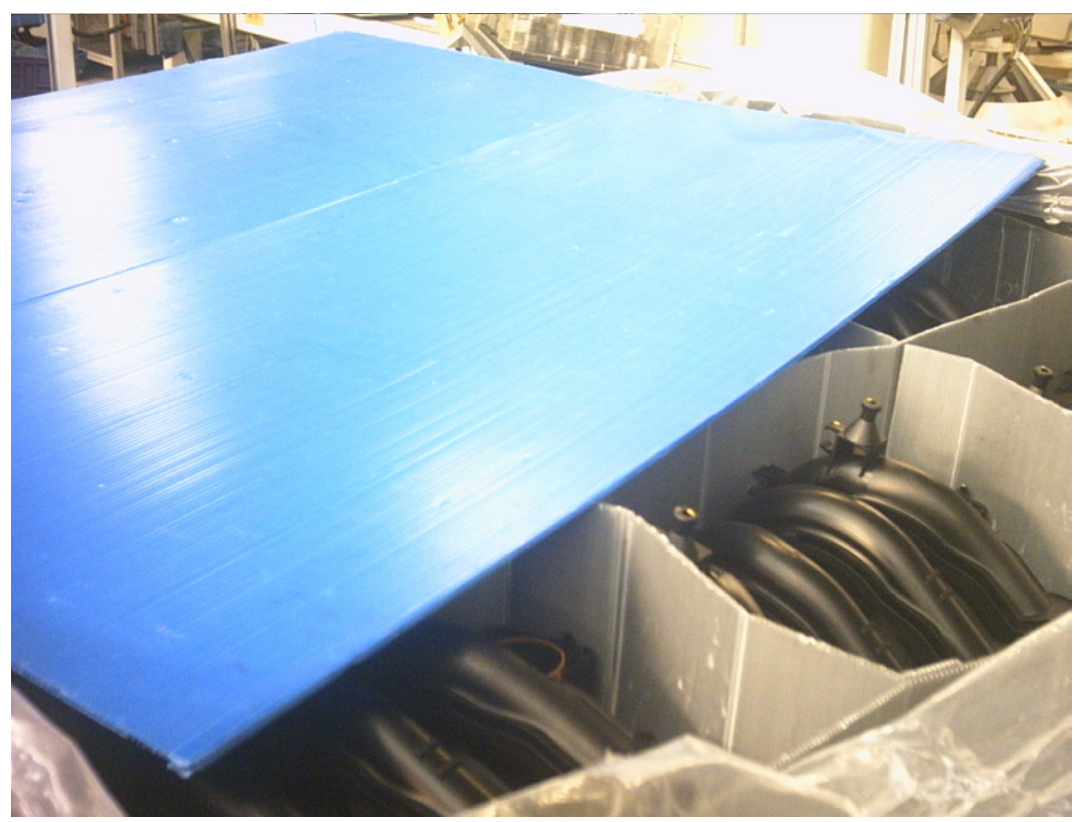

Foto 7 - Caixamóbil com separadores de polionda ("grade”: cinza; "placa”: azul)

- plástico filme: é aplicado externamente a certas embalagens, para proteção extra contra impurezas; alguns desses filmes são termoencolhíveis, isto é, são aplicados e, recebendo calor, se retraem, conferindo à embalagem grande isolamento.

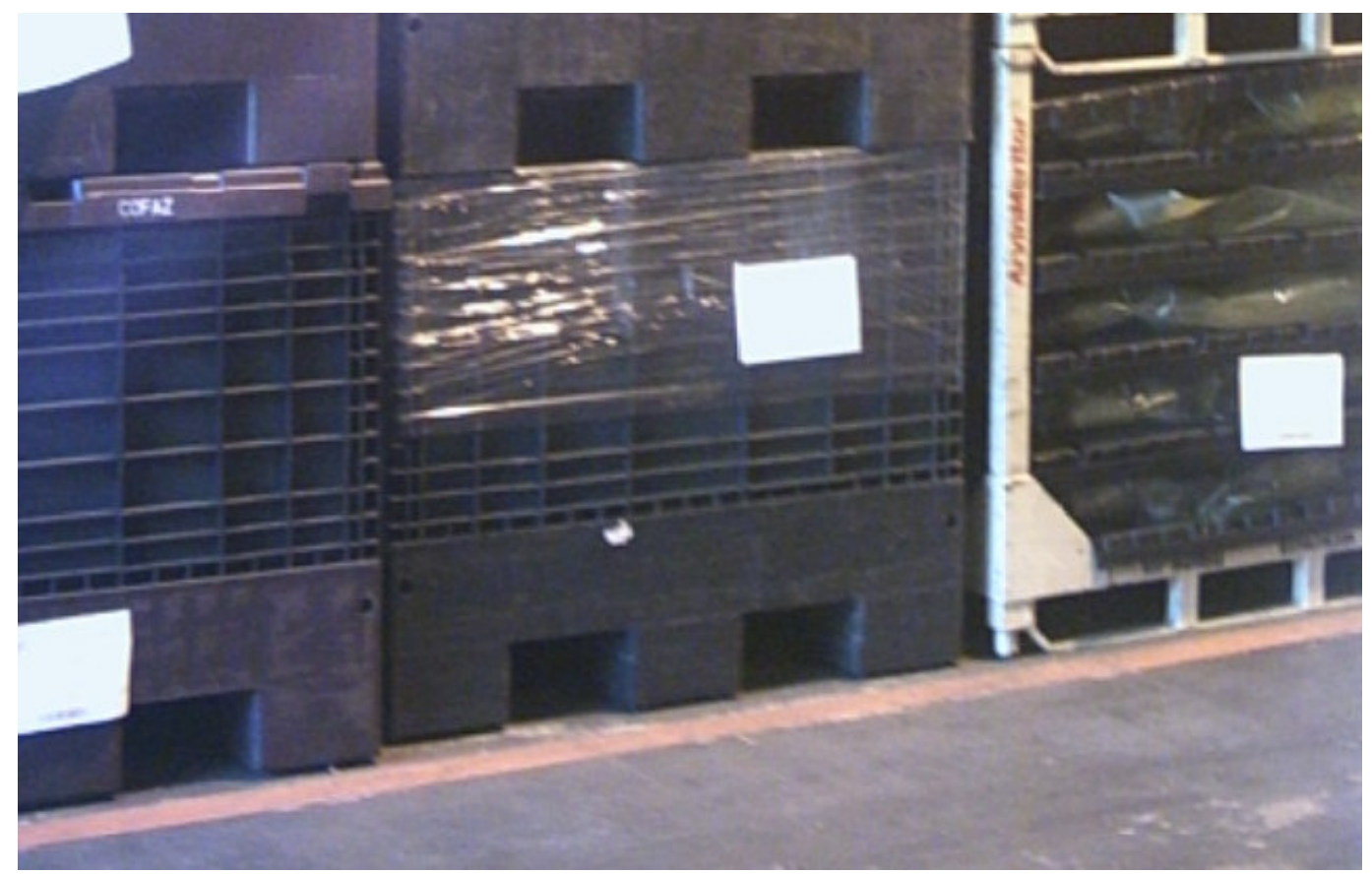

Foto 8 - Caixamóbil envolta por filme plástico (ao centro) 


\subsection{Fluxo das embalagens na planta}

$\mathrm{Na}$ linha EA-111, as embalagens seguem basicamente o mesmo fluxo, independentemente do tipo de motor considerado. As diferenças residem no destino final, como se verá no diagrama abaixo. Foi possível identificar uma etapa anterior à entrada na linha, e que é de fundamental importância para o gerenciamento de embalagens e seus resíduos: o planejamento das próprias embalagens, necessário em situações como a entrada em fabricação de componentes novos ou modificados.

Assim, tem-se:

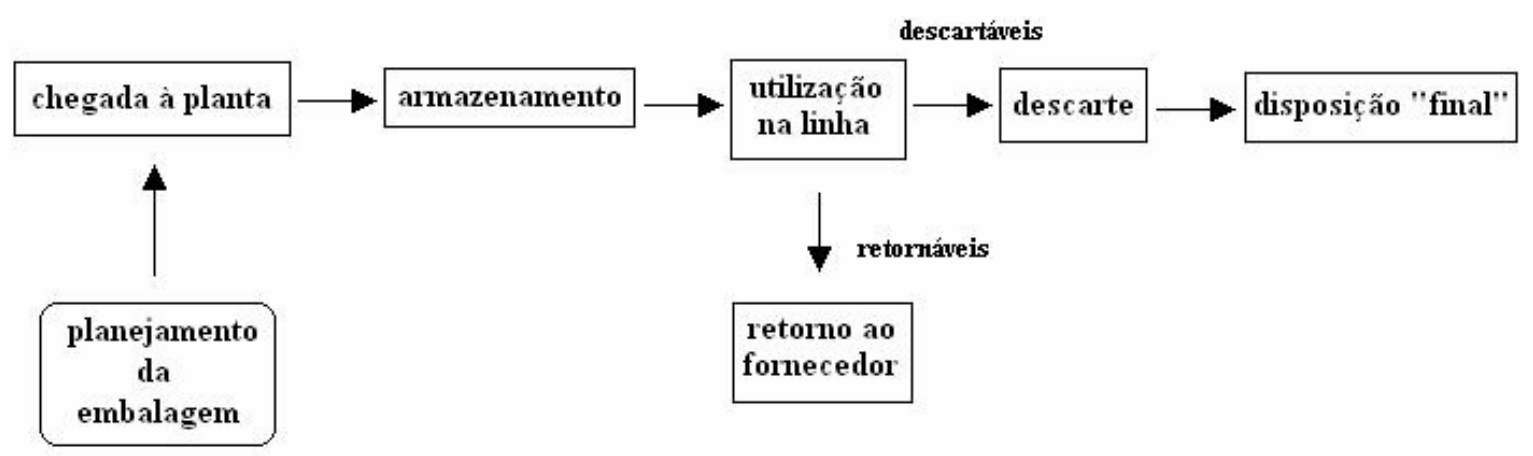

Figura 14 - Fluxo de embalagens na planta da VW

\section{$\underline{\text { O planejamento de uma nova embalagem }}$}

Quando a empresa considera necessária a utilização de um novo componente, seja por ocasião do desenvolvimento de um novo produto ou por modificação de um já existente, define, em conjunto com o fornecedor, três principais características:

- a freqüência de entrega: diária, semanal ou outra

- a forma de entrega: a VW recebe ou vai buscar no fornecedor

- o tipo de embalagem

A nova embalagem, assim, já nasce com um "conceito" definido, nas palavras de um representante do setor de Logística, visto que as exigências quanto ao tipo a ser utilizado já devem ser consideradas desde os primeiros contatos com o fornecedor em potencial.

Uma nova embalagem eventualmente proposta pelo fornecedor é então analisada em conjunto por diversos setores da fábrica, que podem fazer cada qual suas perguntas e exigências. Assim, pode-se ter: 
Logística:

- A embalagem é funcional ou não?

- A embalagem tem medidas padrão?

- Questões relativas à paletização, peso e verticalização: devem ser levados em conta os limites de altura e peso na armazenagem

- Custo do transporte e armazenagem, que são pagos pela VW

Segurança do Trabalho:

- características relativas à ergonomia

- segurança no empilhamento

Qualidade:

- Qual o(s) material(is) da embalagem?

- A qualidade da peça é garantida?

Cada setor pode também estabelecer condições para aprovação. O setor de Qualidade, por exemplo, pode exigir da embalagem alguma garantia extra de qualidade do componente, como, por exemplo, a utilização da camada externa de plástico filme sobre a embalagem para impedir a entrada de impurezas. Quanto aos materiais, foram estabelecidas algumas proibições, como o uso de madeira e papelão. Apenas um tipo de embalagem de papelão foi aprovado: trata-se de uma caixa retornável, utilizada pela Magnetti Marelli, e que apresenta três camadas de papelão, de estrutura semelhante ao compensado de madeira.

Estando todos os setores de acordo, a embalagem é aprovada para utilização, e as especificações são definidas por ocasião do contrato.

A determinação das características da embalagem logo no início do processo de fornecimento é importante, pois condições não estabelecidas de antemão tendem a se converter em fonte de problemas futuros. Uma embalagem retornável, por exemplo, pode ter acessórios descartáveis, como divisórias de papelão, e se essa questão não foi discutida logo durante os contatos iniciais com o fornecedor, mais tarde será difícil obrigá-lo a substituir o material descartável por um equivalente retornável, que representa custo adicional. 
Enquanto esta situação não é resolvida, persiste a geração de resíduos de embalagens; essa presença de material descartável na planta também pode levar à demeritação (penalização) da empresa durante uma auditoria; a título de informação, só durante o período de pesquisa na fábrica ocorreram duas auditorias.

Observa-se, assim, nesta "etapa $n^{\circ} 0$ ", que a relação com os fornecedores consiste numa atividade de grande importância em direção à prevenção da poluição por embalagens.

Foi identificado, ainda, outro instrumento de controle relativo às embalagens: o chamado BOL (Boletim de Ocorrência Logística). Consiste num documento que identifica a ocorrência de algum tipo de não-conformidade. Por exemplo, no caso das embalagens, caso o fornecedor tenha se comprometido a utilizar embalagens retornáveis, e em algum momento faz uso de embalagens de papelão, o setor preenche um BOL e entra em contato com a empresa para pedir explicações. Em caso de reincidência, a VW "multa" o fornecedor, através de desconto de determinado valor da folha de pagamento ("folha de crédito") da empresa em questão, comunicando o motivo desse desconto.

Segundo o representante do setor de Logística, a lógica de uso do BOL baseia-se no princípio de que a VW paga para o fornecedor comprar e utilizar as embalagens retornáveis; em outras palavras, o custo das embalagens está embutido no preço das peças; portanto, a VW tem o direito de exigir sua utilização.

Há algumas exceções a esta política. Por ocasião de um lançamento, por exemplo, a planta pode eventualmente receber embalagens descartáveis para suprir a demanda extra de componentes. Segundo representantes da planta, a aquisição de embalagens retornáveis extras para uso nesses esses períodos não seria compensador porque, no resto do tempo, elas praticamente não seriam utilizadas e, assim, demandariam espaço extra para sua armazenagem.

\section{Etapa 1: chegada do componente à planta}

Neste ponto, há diferenças entre os componentes nacionais e os provenientes do exterior. Os componentes nacionais devem se adequar diretamente ao padrão de embalagens retornáveis. Exemplos disso são os blocos dos motores, que chegam dentro de racks metálicos. Estes racks são colapsíveis, isto é, desmontáveis, de modo que, quando esvaziados, ocupam espaço bem menor nos caminhões, facilitando e barateando o custo do transporte. 


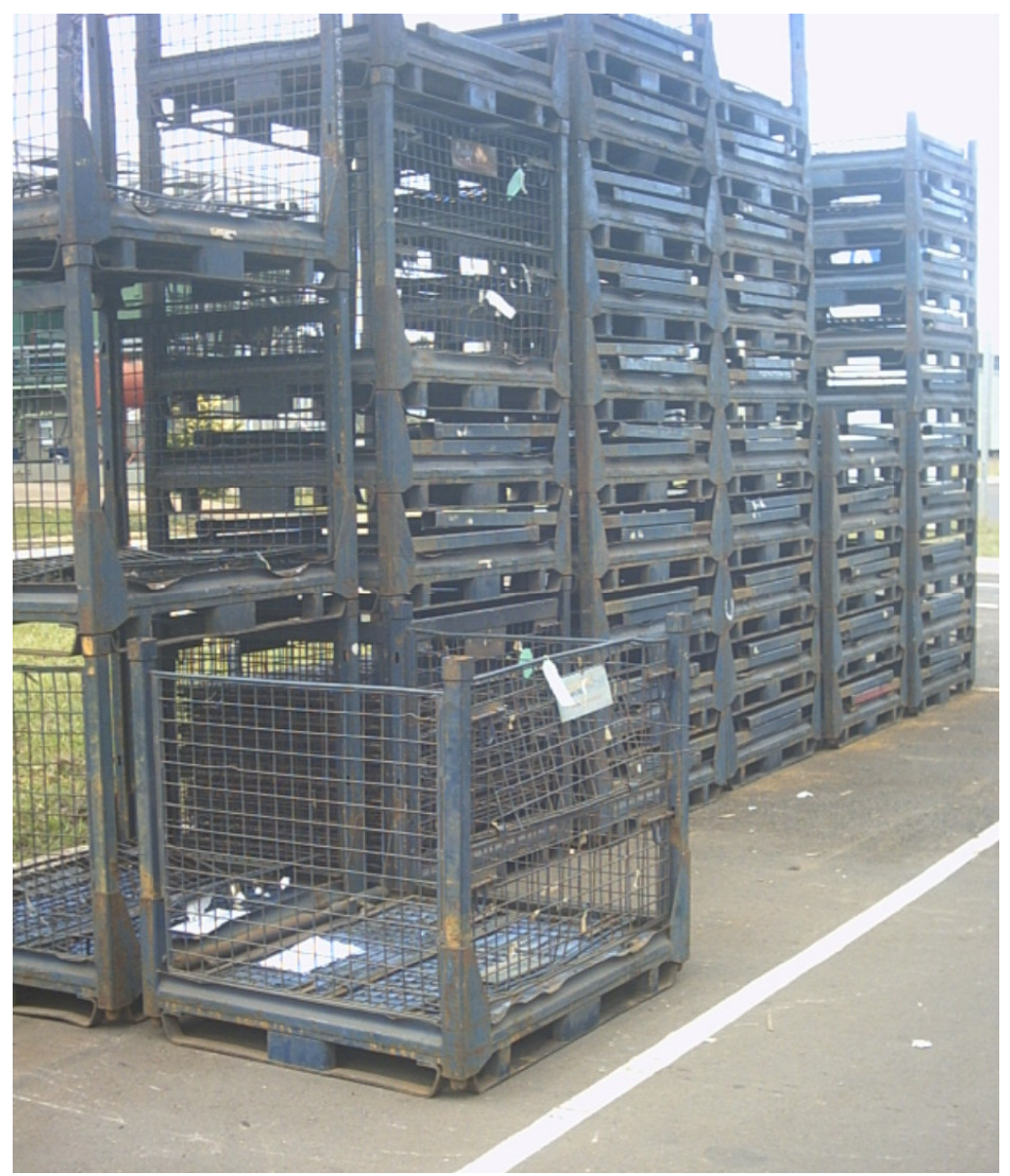

Foto 9 - Racks metálicos vazios no pátio externo da planta

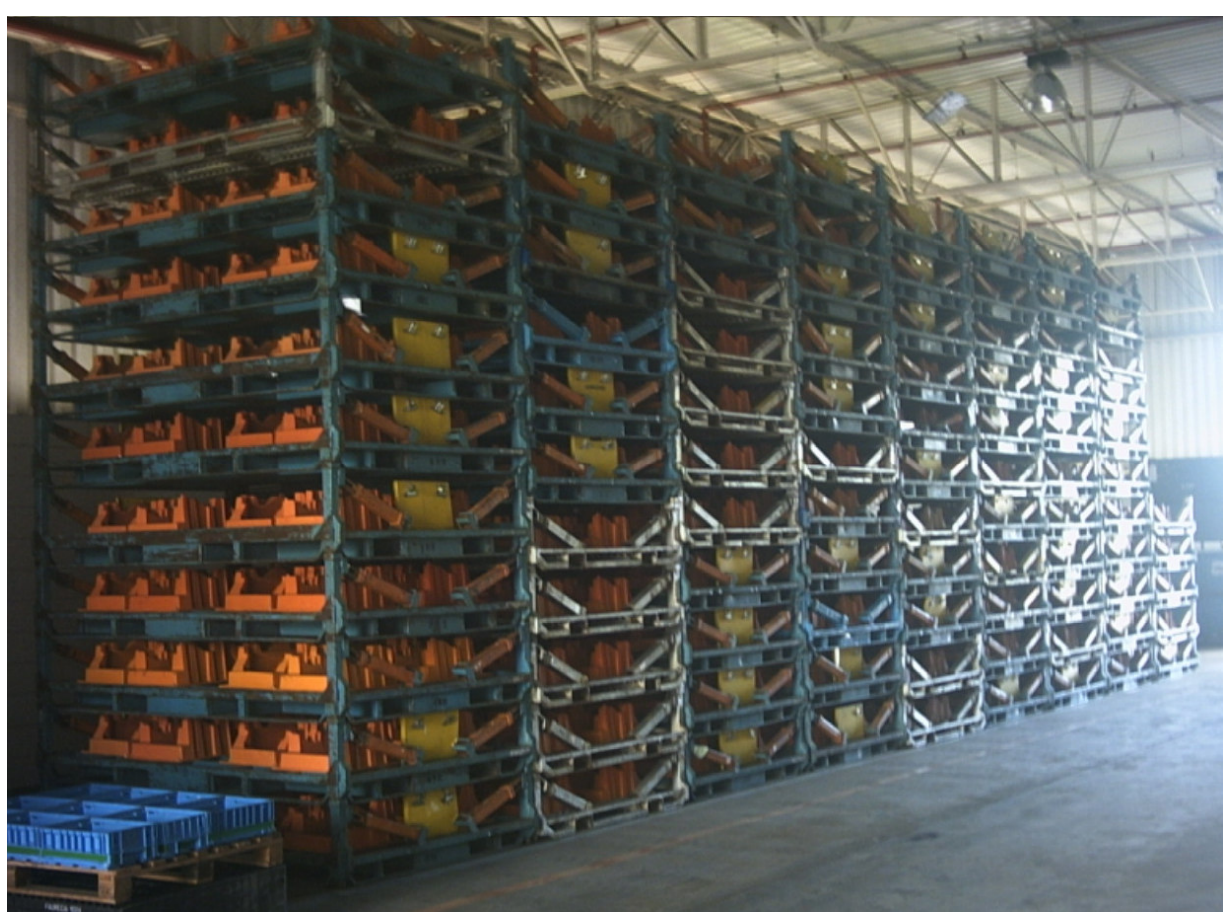

Foto 10 - Racks vazios no pátio interno da planta 
No caso das peças importadas, são utilizadas embalagens retornáveis, como as que abrigam os virabrequins, e não-retornáveis, como as que abrigam o coletor de admissão. Justificou-se esta escolha pelo fato de que o transporte de volta ao fornecedor de embalagens retornáveis vazias, como os racks e outras caixas maiores, aumentaria muito os custos de transporte.

De modo geral, quando os componentes chegam em embalagens descartáveis, é necessário fazer o transbordo de tais componentes. O processo de transbordo consiste simplesmente em retirar as peças da embalagem descartável original e transferi-las para embalagens retornáveis, que as conterão durante o transporte e armazenagem dentro da planta.

As embalagens descartáveis originais provêm de países como o México, Europa (Alemanha) e Argentina. Consistem basicamente em caixas de papelão e caixotes de madeira, no caso de certas peças que vêm da Volkswagen alemã. Os componentes chegam aos portos brasileiros (Santos ou Paranaguá) e são redistribuídos para as unidades de São Bernardo, Taubaté e outras. No caso da planta de São Carlos, as peças que chegam são transferidas para o galpão da SG Logística.

A SG está localizada a cerca de $1,5 \mathrm{~km}$ da planta da Volkswagen, no trevo de acesso à represa do Broa. Em suas instalações, realiza o transbordo das peças das embalagens descartáveis de madeira para embalagens retornáveis, que são de uso exclusivo das duas empresas, circulando entre as plantas. Os resíduos de embalagem gerados na SG são coletados em caçambas da empresa Alô Entulho.

Após a chegada à planta, ocorrido ou não o transbordo, as peças vão para o setor de armazenagem até sua utilização.

\section{Etapa 2: armazenamento}

O tempo de armazenagem na planta antes da utilização do componente é de dois dias, em média. A estocagem é feita em pilhas, sendo que a quantidade de embalagens nessas pilhas pode variar. 
Etapa 3: utilização na linha

$\mathrm{Na}$ linha, as embalagens são dispostas próximo ao ponto de utilização dos componentes. Algumas delas, como as do tipo caixamóbil, são desmontáveis parcialmente, o que facilita a retirada do componente.

Após o esvaziamento, as embalagens reutilizáveis menores podem ser colocadas dentro das maiores, o que facilita o transporte dentro da planta até o setor de armazenagem de embalagens vazias.

Etapa 4: descarte / preparação para retorno ao fornecedor

Os acessórios que são descartados são reunidos em carrinhos dispostos entre as duas seções da linha. Nota-se, na foto a seguir, a presença de cintas plásticas e mantas de plástico bolha.

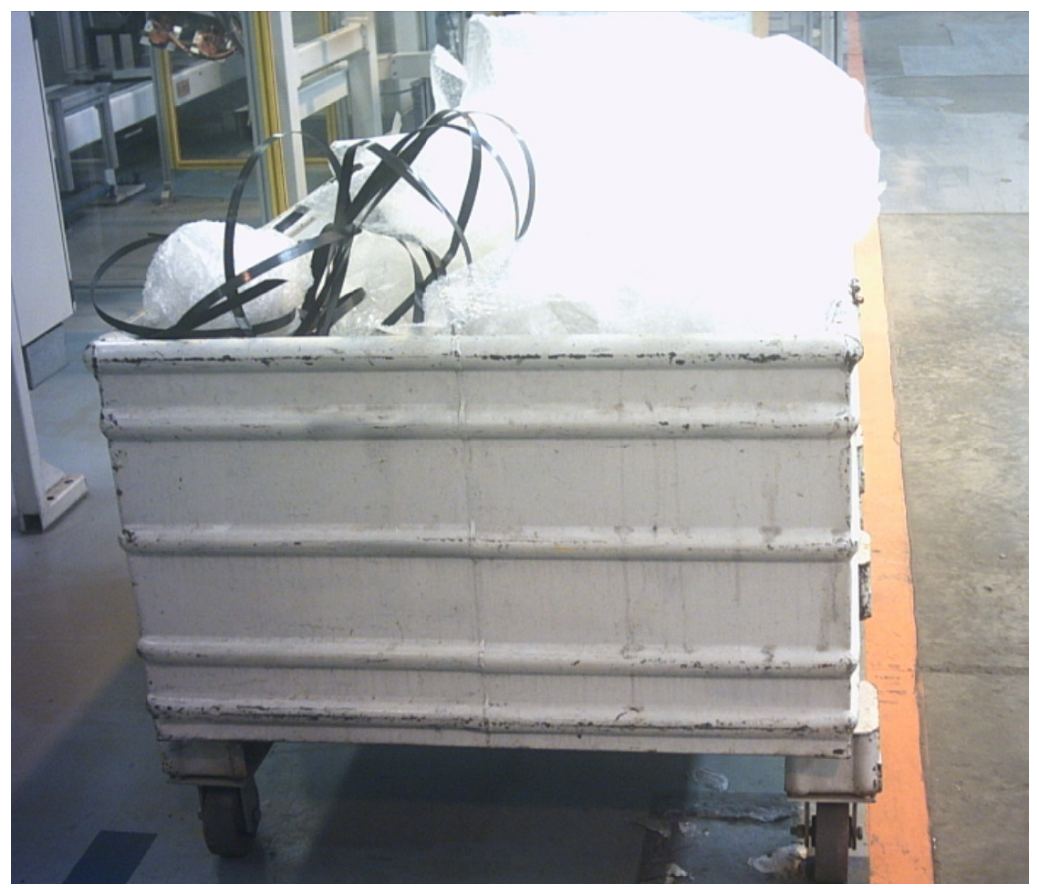

Foto 11 - Carrinho para coleta de descartáveis na linha

Por sua vez, as embalagens retornáveis, após a utilização dos componentes na linha, seguem para um setor de armazenagem especialmente dedicado a elas. Nesse setor, três empregados trabalham no processo de preparação para o retorno: eles retiram eventuais embalagens que tenham sido colocadas dentro das embalagens maiores, e separam as embalagens segundo o fornecedor, uma vez que as embalagens são "exclusivas" de cada fornecedor, e as armazenam em pilhas. Tais pilhas atingem, em 
geral, altura máxima de $6 \mathrm{~m}$, por questões de segurança, e permanecem no setor por 2 a 3 dias, até serem carregadas nos caminhões que as enviarão de volta aos respectivos fornecedores.

Neste ponto, surge outra diferença nos procedimentos. No caso das peças importadas, a empresa se responsabiliza por limpar e "cuidar" dos acessórios das embalagens, pois como se viu, alguns desses acessórios - sacos plásticos, cintas, plástico bolha - são descartados. Já no caso das peças nacionais, o fornecedor da VW é que deve limpar as embalagens que recebe, para posterior reutilização.

Segundo representante do setor de Logística da empresa, a VW, como usuária das embalagens retornáveis, não tem idéia precisa de seu tempo de vida útil; os fornecedores, porém, sabem, tanto que mantêm um plano de substituição de embalagens. De qualquer forma, a vida útil das embalagens depende de variáveis como os cuidados no manuseio e transporte, o material de que são compostas e o peso da peça em questão; peças mais pesadas, por exemplo, podem ir "afundando" a base da embalagem, pouco a pouco. Por fim, cabe ao fornecedor a responsabilidade pelas embalagens retornáveis, depois de inutilizadas.

\section{Etapa 5: disposição final}

Na planta, existe um local próprio para destinação e coleta de resíduos. Trata-se de um pátio externo, próximo às linhas de produção. Nesse local, como na planta da SG, encontram-se caçambas da empresa Alô Entulho, para coleta dos resíduos.

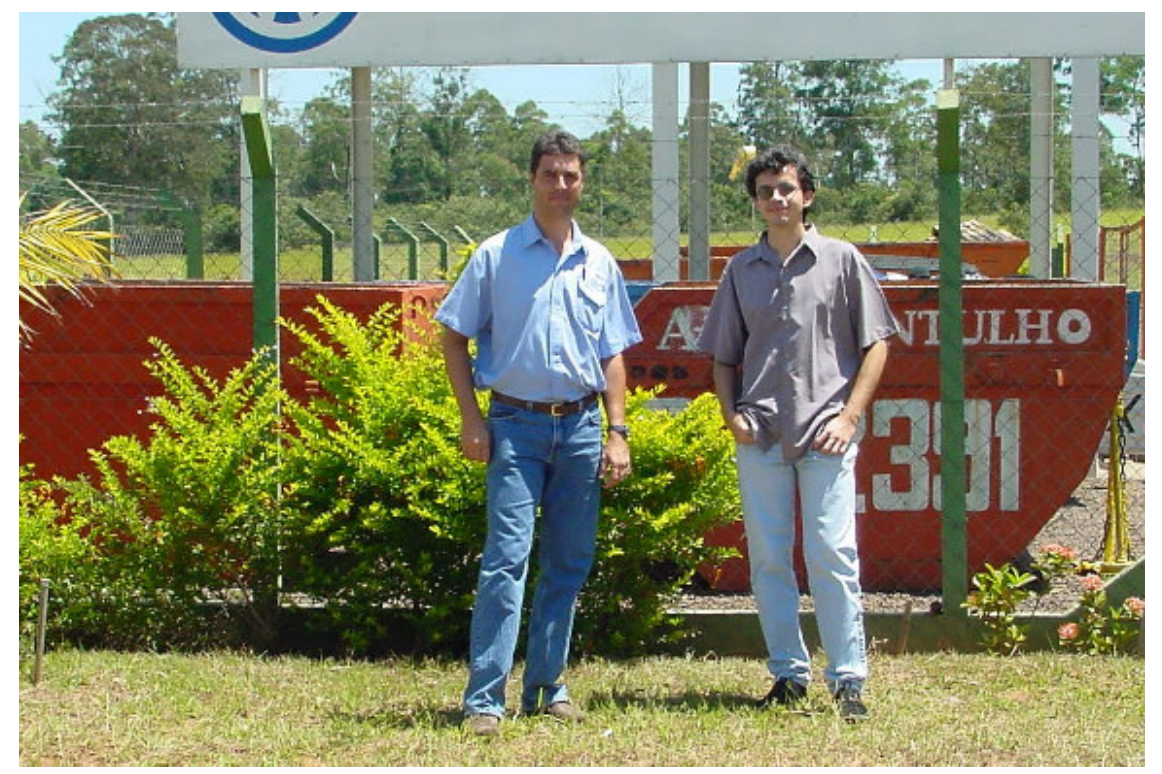

Foto 12 - Pátio externo para coleta de resíduos 


\subsection{A geração de resíduos - os Índices Globais de Resíduos (IGR's)}

A empresa mantém um registro geral dos resíduos gerados em suas instalações; o levantamento dos dados relativos a 2004 foi fechado em torno de março de 2005 e apresentado durante uma auditoria recente.

O registro contém dados sobre os tipos de resíduos gerados e a empresa responsável pelo resíduo - se compra os resíduos para reutilizar, caso dos plásticos e óleos lubrificantes, ou para destruir, como é o caso do lodo de ETE, processado em fornos de cimento. Nestes casos em que o resíduo é revendido para outra empresa, são registradas numa planilha informações como a nota fiscal da negociação, o peso total do resíduo, a data e a forma de envio. Recentemente, por conta das exigências da norma ISO 14001:2004, passou a ser feito um controle dos aspectos econômicos associados ao gerenciamento dos resíduos. Assim, tem-se um balanço de gastos resultantes de análises, envio do material para destruição, entre outras atividades, e da receita: gerada com a venda dos recicláveis.

Os registros existentes na empresa constituem, assim, uma espécie de "histórico" do resíduo, da saída da VW à destinação final, seja ela a venda para reutilização ou reciclagem ou a destruição e disposição. No caso dos resíduos descartáveis, tentava-se, à época das visitas, obter as notas fiscais relativas à venda destes pela empresa responsável, para se ter um registro completo.

Observou-se que, na planilha do registro de resíduos, constam, por exemplo, dados e números relacionados ao total de reagentes utilizados no tratamento de água. Neste caso, já se tem um índice do tipo quantidade de resíduo por motor produzido. No entanto, esses valores são obtidos em relação ao total de motores produzidos no período considerado; isto é, não há índice relativo a um tipo específico de motor. Isso talvez seja dificultado pelo motivo, já levantado anteriormente, de que a linha opera com regime de produção em lotes, e não seqüencial. Porém, ainda que, dessa forma, seja difícil avaliar o impacto de cada tipo de motor no total de resíduos gerados, a diferença possivelmente não seja tão grande de um tipo para outro. Caso a empresa fabricasse produtos muito diversos - por exemplo, aspiradores e geladeiras - esses impactos talvez fossem diferentes em quantidade.

No registro de resíduos, os materiais relacionados às embalagens são o plástico, o papel e o papelão. O representante da empresa estima que $90 \%$ do total de resíduos plásticos sejam resultantes de embalagens, aí incluídos os sacos, placas de polionda e 
outros acessórios. Já os dados relativos a resíduos de papel e papelão incluem material de escritório, por exemplo.

Por ocasião das visitas, surgiu a oportunidade de realizar alguns cálculos a partir dos dados disponíveis. Os números obtidos foram denominados "Índices Globais de Resíduos" (IGR's).

Com os dados constantes da planilha de resíduos gerados em 2004 em função do total de motores produzidos na planta no mesmo período, foram obtidos os seguintes IGR's:

Quadro 7 - Índice Global de Resíduos (IGR) - plásticos

\begin{tabular}{|l|l|}
\hline Total gerado em 2004 & $48465 \mathrm{Kg}$ \\
\hline Motores produzidos no período & 355700 \\
\hline IGR (plásticos) & $0,136 \mathrm{Kg} /$ motor fabricado \\
\hline
\end{tabular}

Quadro 8 - Índice Global de Resíduos (IGR) - papel e papelão

\begin{tabular}{|l|l|}
\hline Total gerado & $60290 \mathrm{Kg}$ \\
\hline Motores produzidos no período & 355700 \\
\hline IGR (papel e papelão) & $\approx 0,170 \mathrm{Kg} /$ motor fabricado \\
\hline
\end{tabular}

A utilização de indicadores numéricos como os Índices Globais de Resíduos é importante por permitir uma primeira estimativa dos resíduos gerados em uma empresa em função de seu volume de produção.

\subsection{Análise dos resíduos relativos ao produto escolhido}

O setor de produção propriamente dito da empresa divide-se em duas partes, chamadas comumente de 'linhas' e denominadas Rumpf e ZP4. Todos os tipos de motores fabricados na linha EA-111 passam por ambas as seções, representadas nos diagramas de fluxo apresentados na página seguinte. 


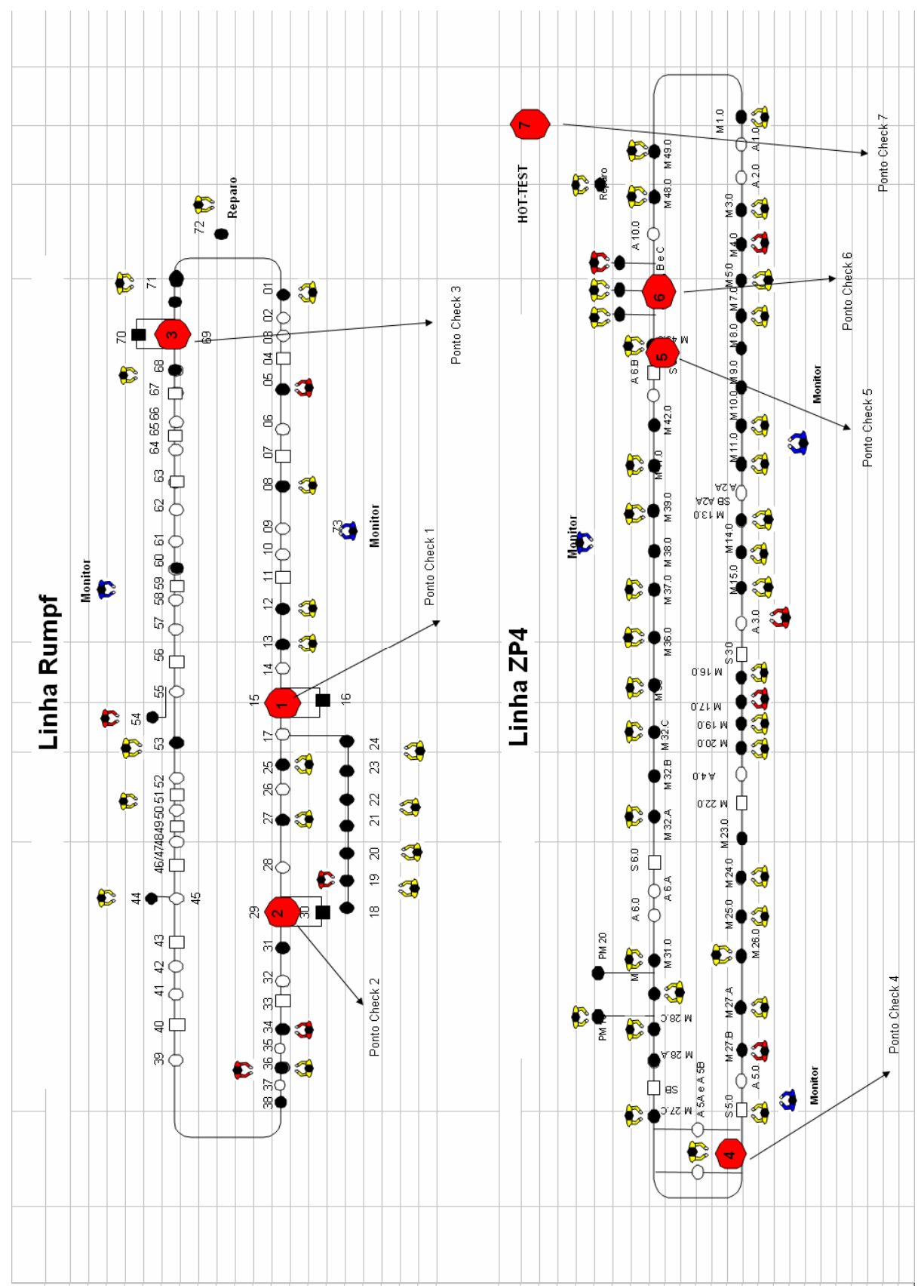

Figura 15 - Diagrama de fluxo (linha EA-111)

A análise da linha de produção da empresa e das informações e bancos de dados por ela disponibilizados permitiu a coleta de dados que foram reunidos em planilhas, apresentadas nas páginas seguintes. Nelas, constam a relação de componentes, o ponto da linha em que eles são utilizadas, seus fornecedores e cidades de origem, as embalagens correspondentes e o descarte gerado a partir de cada uma, quando existe. 
Elementos como óleos lubrificantes, silicone e massas foram desconsiderados; isto porque apenas uma pequena quantidade desses elementos está envolvida na fabricação de uma unidade do produto considerado; portanto, somente a fabricação de grandes quantidades do produto leva ao esvaziamento da embalagem que continha tais elementos - o "consumo" de embalagens como essas na fabricação do produto em questão foi considerada desprezível. Em estudos que se estendam por períodos de tempo mais longos, poderá ser necessário considerar a geração de resíduos compostos por tais embalagens. 
Quadro 9 - Componentes e embalagens (linha Rumpf)

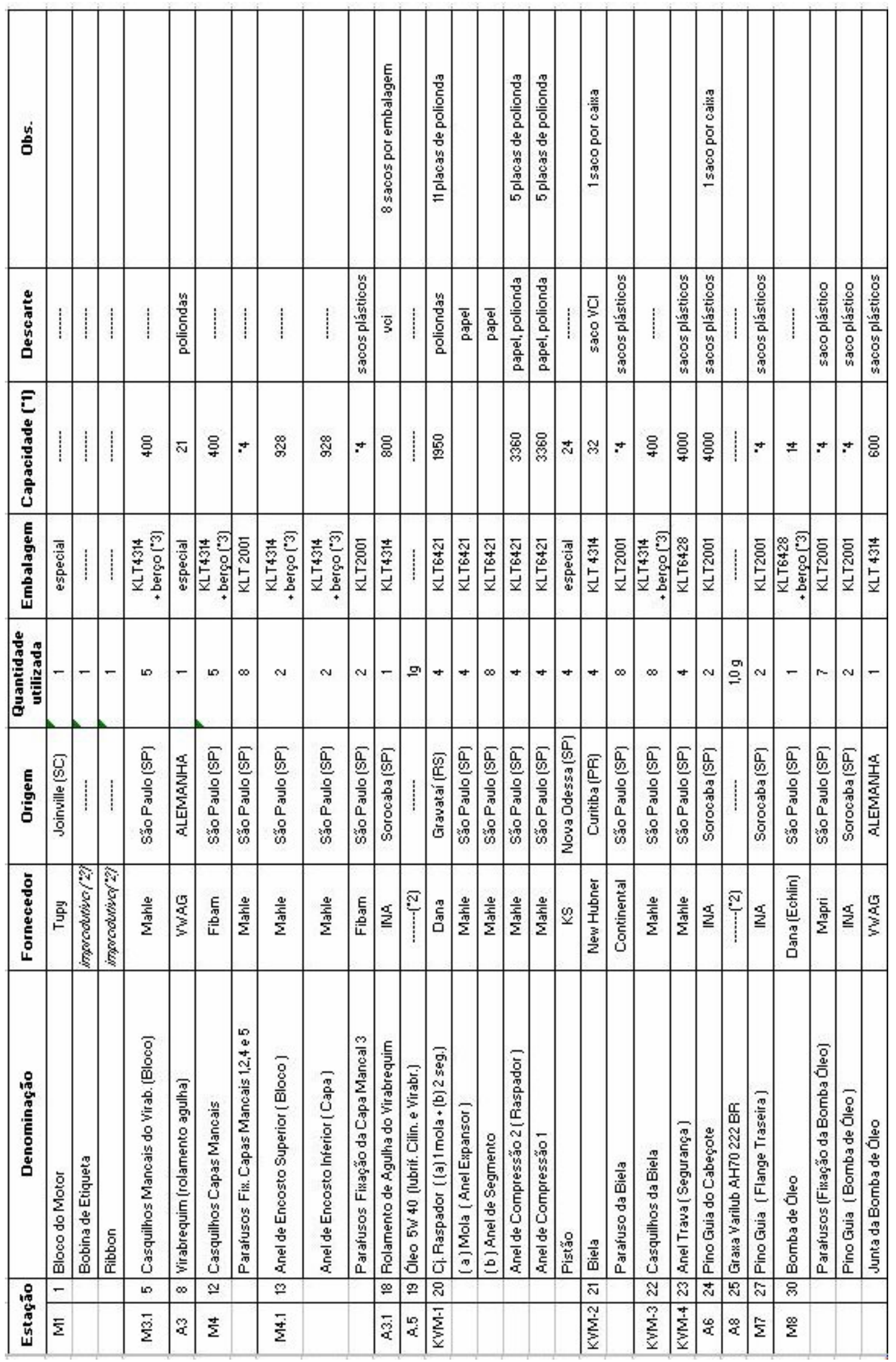


Quadro 9 (cont.)

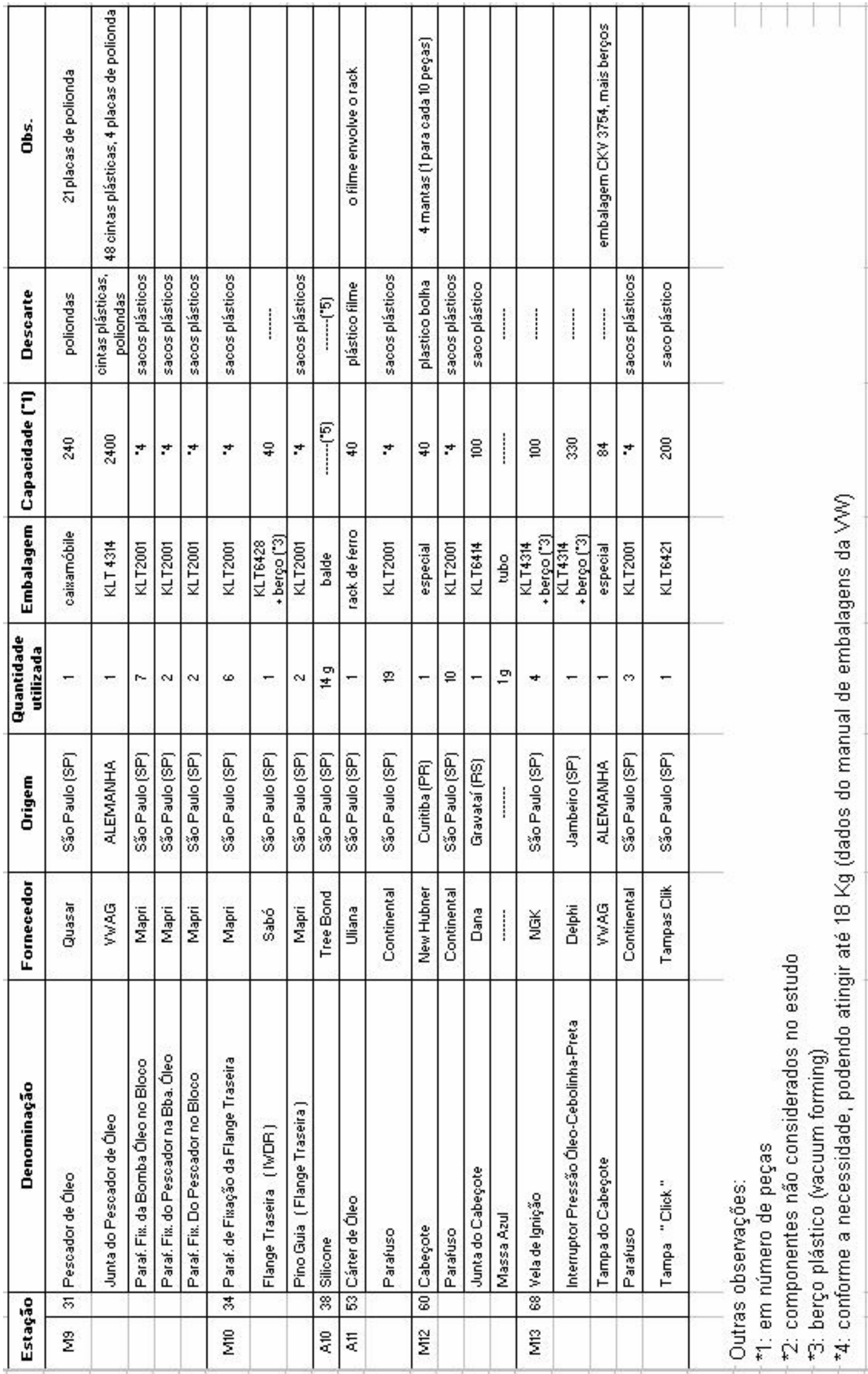


Quadro 10 - Componentes e embalagens (linha ZP4)

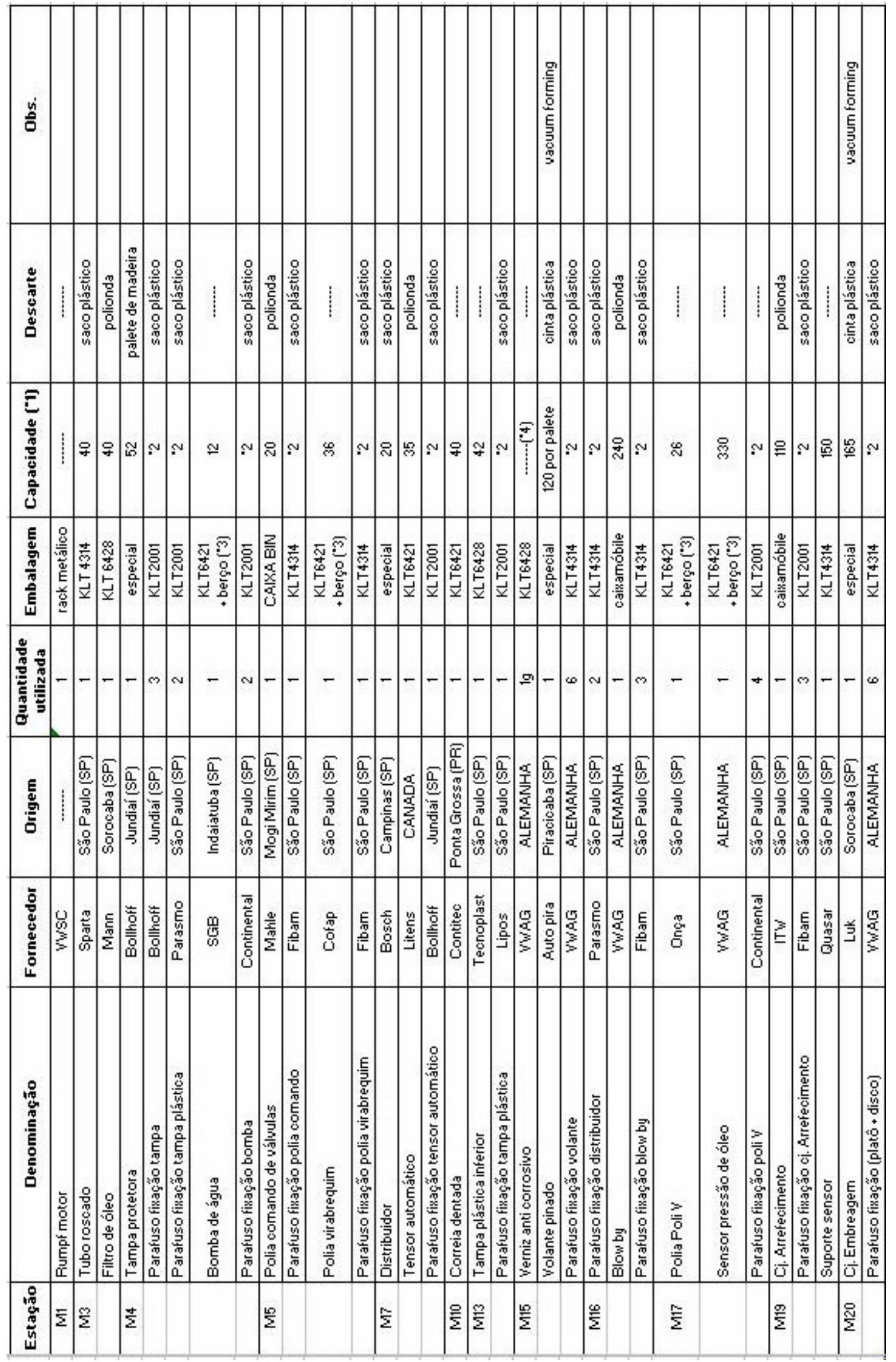


Quadro 10 (cont.)

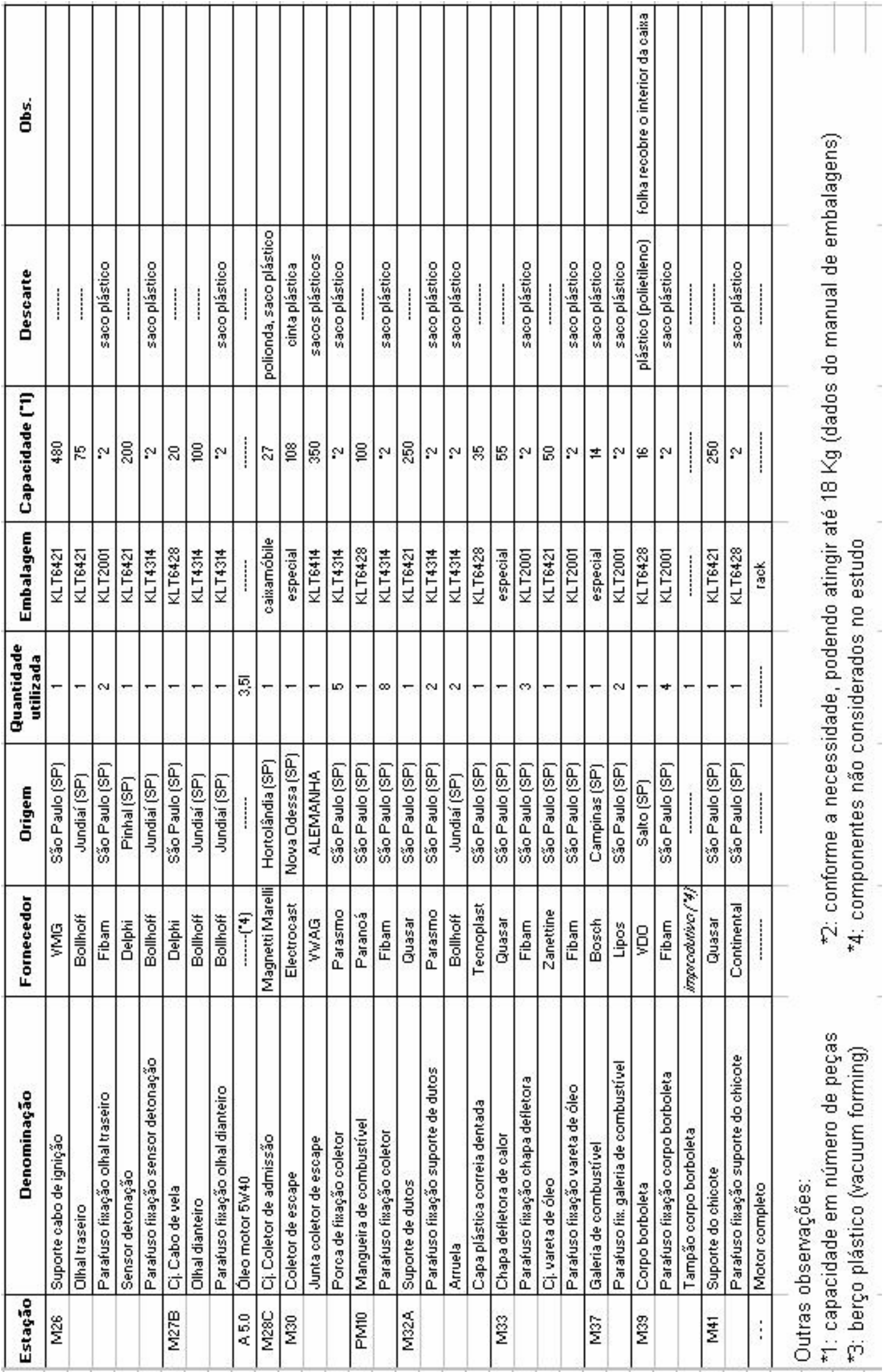


Os dados coletados permitiram confirmar a informação de que virtualmente não há geração de resíduos diretamente a partir das embalagens. Contudo, observou-se a geração de resíduos correspondentes aos acessórios que acompanham parte das embalagens.

Tendo como base de estudo este tipo de descarte, foram propostos e determinados outros índices que receberam o nome de Índices de Resíduos de Embalagens, ou IRE's.

A interpretação dos dados numéricos consistiu em duas análises, cada qual permitiu a determinação de um tipo de índice de resíduo. 
ANÁLISE 1: determinação da porcentagem de embalagens cujos acessórios se convertem em resíduo

Os resultados foram os seguintes:

Tabela 1 - Embalagens e geração de descarte de acessórios

\begin{tabular}{lcc}
\hline & Quantidade & \% do total \\
\hline Embalagens que geram descarte & 69 & 67,0 \\
Embalagens que não geram descarte & 34 & 33,0 \\
Total & 103 & 100,0 \\
\hline
\end{tabular}

Gráfico 1 - Embalagens - participação na geração de resíduos

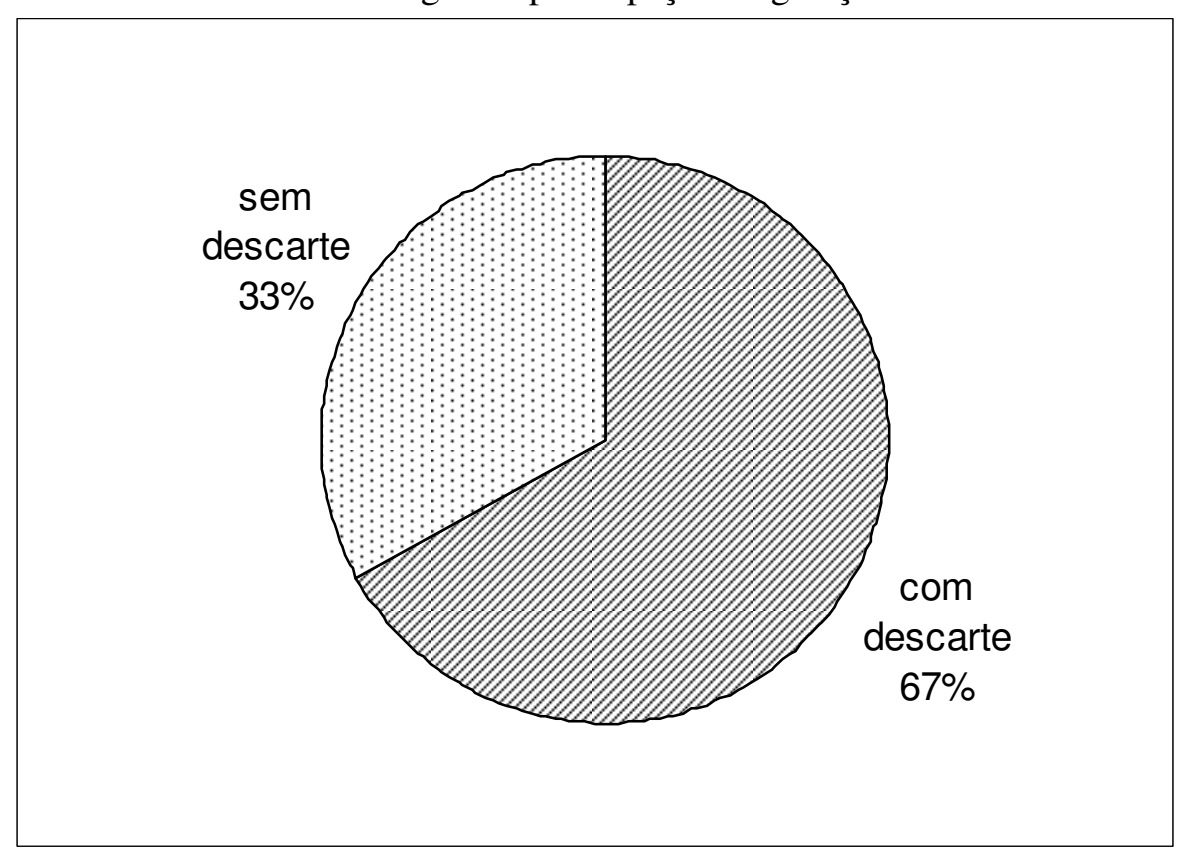

Indices propostos : ECD e ESD (Embalagens Com / Sem Descarte)

O ECD e o ESD são índices relativos, respectivamente, à quantidade de embalagens com descarte e embalagens sem descarte. Em termos numéricos, derivam das porcentagens obtidas, havendo um simples arredondamento de forma a se obter números inteiros.

Quadro 11 - Índices de Resíduos de Embalagens: ECD e ESD

\begin{tabular}{|c|c|c|}
\hline Índices & Valores associados & Objetivo \\
\hline ECD & 67 & minimizar \\
\hline ESD & 33 & maximizar \\
\hline
\end{tabular}


ANÁLISE 2: determinação da porcentagem representada por cada material, dentre os acessórios descartados. Foram obtidos os seguintes dados:

Tabela 2 - Materiais e ocorrências de descarte

\begin{tabular}{lc}
\hline \multicolumn{1}{c}{ Tipo de descarte } & Ocorrências de descarte \\
\hline Sacos plásticos & 47 \\
Poliondas & 12 \\
Cintas plásticas & 4 \\
Papel & 4 \\
Sacos VCI & 2 \\
Palete de madeira & 1 \\
Plástico (polietileno) & 1 \\
Plástico bolha & 1 \\
Plástico filme & 1 \\
Total & $\mathbf{7 3}$ \\
\hline
\end{tabular}

OBS.: Há embalagens que geram dois tipos de descarte. Assim, ao se somar este total de 73 ocorrências com o número de embalagens que não geram descarte, que é de 34, obtém-se o resultado incorreto de 107 embalagens. O número total correto de embalagens é 103, como já apresentado.

Considerando primeiramente o total de ocorrências de descarte e, depois, o total de embalagens, obtêm-se as seguintes porcentagens, para cada tipo de material:

Tabela 3 - Materiais - participação nas ocorrências de descarte

\begin{tabular}{lccc}
\hline Material & $\mathbf{N}^{\circ}$ de ocorrências & $\begin{array}{c}\text { \% do total de } \\
\text { ocorrências }\end{array}$ & $\begin{array}{c}\text { \% em relação ao } \\
\text { total de embalagens }\end{array}$ \\
Plásticos & 68 & 93,2 & 66,0 \\
Papel & 4 & 5,5 & 3,9 \\
Madeira & 1 & 1,4 & 1,0 \\
\hline
\end{tabular}

Graficamente: 
Gráfico 2 - Acessórios - material descartado

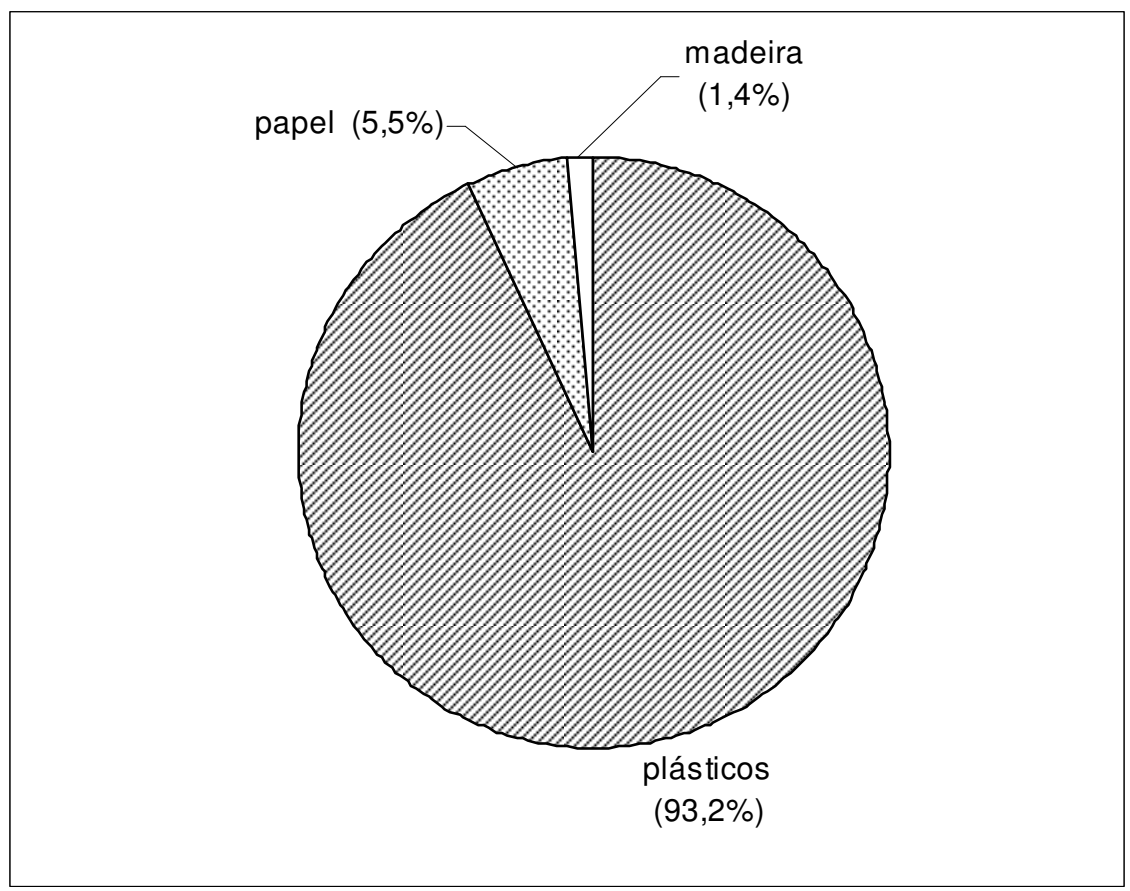

Índices propostos: ID1 e ID2 (Índices de descarte 1 e 2)

O ID1 e o ID2 apontam a freqüência com que um determinado material é descartado. O ID1 reflete a participação de cada um dos materiais no total de ocorrências de descarte observadas. O ID2, por sua vez, aponta a ocorrência de descarte de cada material em relação ao total de embalagens envolvidas. Ambos derivam das porcentagens obtidas na tabela anterior

Quadro 12 - Índices de Resíduos de Embalagens: ID1 e ID2

\begin{tabular}{|c|c|c|}
\hline Material & ID1 & ID2 \\
\hline Plásticos & 93 & 66 \\
\hline Papel & 6 & 4 \\
\hline Madeira & 1 & 1 \\
\hline
\end{tabular}




\section{CONSIDERAÇÕES FINAIS - CONCLUSÕES E SUGESTÕES PARA TRABALHOS FUTUROS}

Durante e após a realização da pesquisa, foram obtidas as seguintes conclusões, a seguir apresentadas divididas em itens:

\section{1) Sobre a metodologia e as limitações do estudo realizado}

A metodologia inicialmente definida não pôde ser aplicada na íntegra em razão do regime de produção em lotes, observado na planta. Conclui-se, dessa forma, que um estudo de embalagens utilizadas em uma indústria depende do regime de produção da empresa, que deve portanto ser analisado previamente.

Também foi observado que, se por um lado, há embalagens que geram dois tipos de descarte, há casos onde um só acessório abriga todos os componentes da embalagem. Exemplos disso são os inúmeros tipos de parafusos: um só saco plástico abriga centenas dessas peças, e na produção de uma unidade do motor, são utilizadas apenas algumas dezenas ${ }^{9}$. Como só há descarte após o esvaziamento do acessório, nesses casos tal descarte só ocorrerá após algum tempo - isto é, após a produção de uma certa quantidade de motores. Em outras palavras, o estudo da geração de resíduos de embalagem é também dependente do lote a ser considerado.

\section{2) Sobre a situação da empresa}

A principal medida em vigor pela planta com vistas à prevenção da poluição por embalagens foi, com efeito, a adoção de embalagens reutilizáveis - a pesquisa procurou não apenas destacar esse fato, como também suas implicações, sobretudo no campo logístico.

O contato com fornecedores tem preocupações evidentemente econômicas, porém acaba se tornando também uma medida importante visando à prevenção da poluição, uma vez que os requisitos relativos às embalagens também prevêem que elas sejam reutilizáveis diversas vezes, e que, no fim de sua vida útil, os materiais que as compõem possam ser reaproveitados de alguma forma.

Quanto ao fluxo da embalagem na planta, é interessante observar que em ambas as interfaces da VW com o "mundo exterior", isto é, a entrada de material e a saída de

\footnotetext{
${ }^{9}$ A partir da planilha da linha ZP4, observa-se que, ainda que todos os parafusos utilizados fossem do mesmo tipo - o que não é o caso - seriam necessários 65 deles na montagem de uma unidade do motor.
} 
resíduos, o gerenciamento das embalagens e de seus resíduos é feito através da terceirização de serviços:

- na entrada de material: a SG Logística

- na saída de resíduos: a Alô Entulho

Essa divisão de funções no gerenciamento de embalagens e seus resíduos implica na necessidade de um trabalho em conjunto, situação em que todas as organizações envolvidas devem necessariamente prestar contas de seu desempenho, pois somente assim se pode ter certeza sobre a real eficiência do sistema de gerenciamento. Essa interação entre as empresas não foi avaliada na presente pesquisa, uma vez que fugia ao escopo inicial desta.

\section{3) Sobre os resíduos gerados}

Como já era esperado, os acessórios das embalagens representam o problema principal a ser equacionado. Alternativas encontradas pela planta são a busca de formas de reaproveitamento, como material para acolchoamento, por exemplo, e a destinação de materiais como madeira e papelão, para entidades assistenciais do município.

Na prática, foram observadas situações em que se estabeleceu um compromisso entre a geração de resíduos e a garantia da qualidade final do produto. O exemplo mais marcante desse compromisso é o uso de plástico filme externamente na embalagem, que implica simultaneamente em geração adicional de resíduo, e garantia extra da qualidade do produto.

Deve-se ressaltar, por fim, a necessidade do desenvolvimento contínuo de embalagens e seus respectivos acessórios, com vistas a reduzir a quantidade de material que precise ser destinado à reciclagem ou outras formas de gerenciamento, após ser utilizado apenas uma vez.

\section{4) Sobre os índices propostos (IRE's)}

A adoção de índices para acompanhar o desempenho ambiental e orientar as ações do SGA de uma empresa está prevista na norma ISO 14001. Nesse sentido, os IRE's poderiam ser adicionados à lista dos chamados KPI's (Key Performance Indicators, ou Indicadores-Chave de Desempenho), utilizados na planta, para refletir o desempenho da empresa em diversos aspectos. 
Dada a importância da relação indústria-fornecedores, os IRE's podem atestar não apenas a eficiência ecológica das embalagens envolvidas, mas também um aspecto de eficiência ecológica da cadeia de suprimentos da empresa.

\section{5) Sobre as empresas em geral}

A adoção de medidas visando à prevenção da poluição requer o conhecimento prévio de uma série de informações sobre os processos produtivos de uma empresa. No caso da pesquisa realizada, a partir do diagrama do fluxo da produção e da relação de embalagens utilizadas, identificam-se os pontos em que os componentes entram em cena, bem como os pontos de geração de resíduos de embalagens. Assim, é possível acompanhar e analisar de forma integrada os fluxos do produto e dos resíduos dentro da planta, como antecipado no item 3.2.3. - "A embalagem de uso industrial e o processo produtivo".

As medidas a serem adotadas devem considerar não apenas o ambiente interno da empresa, mas também seus aspectos externos. Através do estudo de caso, pôde-se perceber que a relação com os fornecedores constitui fator que determina o sucesso (ou não) de medidas visando a prevenção da poluição por embalagens, especialmente no caso de empresas montadoras. Esta tendência é, já há algum tempo, chamada de "greening”, ou "esverdeamento", da cadeia de suprimentos: as empresas de modo geral e seus respectivos fornecedores devem trabalhar juntos, de forma a maximizar seu desempenho ambiental, levando em conta as implicações econômicas e logísticas associadas. Nota-se que, no caso da empresa analisada, esta relação já se mostra bastante estreita.

Por fim, conclui-se que, idealmente, a prevenção da poluição já deve ser uma preocupação antes mesmo de a empresa iniciar suas atividades. É evidente que abandonar velhos hábitos é mais difícil e custoso do que buscar a mudança e o aperfeiçoamento contínuos desde o início. Ainda assim, uma vez que a empresa já esteja operando dentro de certos padrões e costumes, é imperativo elaborar e adotar um plano que deve objetivar não só a redução da poluição eventualmente gerada, mas principalmente a sua prevenção, e que considere os resíduos direta e indiretamente associados aos processos de fabricação. 
Outra conclusão importante do trabalho é a existência de uma enorme gama de possibilidades para pesquisas na área da prevenção da poluição aplicada às embalagens. Apenas com relação às embalagens utilizadas em empresas, como foi o caso deste estudo, podem ser realizados estudos como os seguintes:

1) Repetição do estudo realizado, aplicando-se a mesma metodologia, porém alterando-se a quantidade da amostra: a precisão dos indicadores obtidos pode melhorar e eles podem se tornar mais "reais", se no estudo for considerado não apenas uma unidade do motor, e sim um lote inteiro ou uma quantidade qualquer a ser determinada previamente. Durante a produção deste lote, todos os resíduos de embalagem devem ser coletados, para posterior separação, pesagem e análise. Os indicadores assim obtidos refletiriam a quantidade de resíduos gerada pelo lote considerado; em outras palavras, seriam obtidas relações como "Kg de resíduo de embalagens / motores fabricados".

2) Realização do levantamento feito nesta pesquisa, abordando todos os modelos da linha: pode-se ter uma noção geral dos resíduos de embalagens - plásticas, de papel e papelão, entre outras - geradas na planta ou, ao menos, estabelecer um comparativo entre os "desempenhos" das embalagens.

3) Obtenção de outros índices relativos às embalagens retornáveis, como por exemplo, o número de ciclos de utilização por motor fabricado - quanto maior o número, melhor o desempenho. Tais dados, no entanto, precisariam ser obtidos junto aos fornecedores de componentes, pois a empresa que utiliza os componentes pode não ter uma idéia precisa da freqüência da substituição, como foi o caso da pesquisa.

4) Visita a fornecedores de peças para empresas montadoras; observar a relação das duas empresas, quanto à questão das embalagens retornáveis:

- vida útil dessas embalagens: verificar se o fornecedor tem idéia precisa ou, ao menos, aproximada;

- existência ou não de um plano de substituição de embalagens que chegam ao fim da vida útil;

- destinação de tais embalagens, após o fim de sua vida útil - possibilidades quanto à reutilização ou reciclagem. 
5) Visita a fabricantes de embalagens retornáveis - obtenção de dados como:

- tempo de vida útil das embalagens, em termos de ciclos de utilização;

- o material utilizado;

- novas possibilidades sendo estudadas quanto à forma e disposição dos componentes no interior da embalagem, que permitam não apenas a otimização de espaço, mas também a diminuição no uso de acessórios para proteção e fixação dos componentes.

6) Avaliação do consumo de energia, geração de resíduos e emissões atmosféricas nas fases de transporte (idas e voltas entre a planta e o fornecedor).

7) Realização de estudos envolvendo a determinação dos IRE's para as embalagens descartáveis, obtendo índices como a porcentagem das embalagens que se tornam resíduos: empresas que ainda utilizem embalagens descartáveis podem empregar um índice como esse para indicar oportunidades de substituição pelas retornáveis, bem como acompanhar a evolução do processo.

8) Avaliação da interação entre empresas que estabelecem uma relação como a observada entre a VW, a SG e a Alô Entulho:

- quais as condições inicialmente estabelecidas para essa parceria;

- de que forma ela é avaliada pela empresa 'principal';

- qual o grau de conhecimento que a empresa 'principal' tem sobre as atividades das demais - recebe ou procura obter informações das parceiras sobre o desempenho destas? 


\section{REFERÊNCIAS BIBLIOGRÁFICAS}

ALMEIDA, L. T. (1998). Política ambiental: uma análise econômica. Ed. Unesp/Papirus.192p.

ABEAÇO - ASSOCIAÇÃO BRASILEIRA DE EMBALAGENS DE AÇO (2004).

Disponível em: <www.abeaco.org.br>. Acesso em 27 set. 2004.

ABNT - ASSOCIAÇÃO BRASILEIRA DE NORMAS TÉCNICAS (1996a). NBR ISO 14.001 - Sistemas de Gestão Ambiental - Especificação e diretrizes para uso.

(1996b). NBR ISO 14.004 - Sistemas de Gestão Ambiental - Diretrizes gerais sobre princípios, sistemas e técnicas de apoio.

(2005). Progresso de normas técnicas (em maio de 2005). Disponível em: <http://www.abnt.org.br/cb38/Arquivos/PROGRESSO\%20DE\%20NORMAS.pdf>. Último acesso em 17 jul. 2005.

ABPO - ASSOCIAÇÃO BRASILEIRA DE PAPELÃO ONDULADO (2004). Disponível em: <www.abpo.org.br>. Acesso em 28 set. 2004.

\section{ABRAPEX - ASSOCIAÇÃO BRASILEIRA DE POLIESTIRENO EXPANDIDO} (2004). O que é EPS. Disponível em: <http://www.abrapex.com.br/01OqueeEPS. html>. Acesso em 28 set. 2004.

ABRE - ASSOCIAÇÃO BRASILEIRA DE EMBALAGEM (2003a). Disponível em: <www.abre.org.br/conheca_ma.htm>. Acesso em 24 set. 2003.

(2003b). Informações sobre análise de ciclo de vida e ecodesign. Disponível em: $<$ http://www.abre.org.br/ecodesign.htm>. Acesso em 24 set. 2003.

(2005a). Estatísticas do setor de embalagens. Disponível em: <http://www.abre.org.br/centro_dados.php>. Último acesso em 17 jul. 2005. (2005b). Normas em vigor do comitê CB-23, da ABNT, relativas a embalagens relação atualizada em janeiro de 2005. Disponível em: <http://www.abre.org.br/cb23_normas.php>. Último acesso em 17 jul. 2005.

BISHOP, P.L. (2000). Pollution prevention: fundamentals and practice. New York: McGraw Hill. 699 p.

BRASIL (1975). Decreto 76.389, de 3 de outubro de 1975. Dispõe sobre as medidas de prevenção e controle da poluição industrial de que trata o Decreto-Lei 1.413, de 14 de agosto de 1975, e dá outras providências. Disponível em: <http://www.ufpa.br/numa/legislacao_brasil/dec_76389_br.htm>. Acesso em 31 ago. 2004. 
(1975). Decreto-Lei 1413, de 14 de agosto de 1975. Dispõe sobre o controle da poluição do meio ambiente provocada por atividades industriais. Disponível em: <http://www.lei.adv.br/1413-75.htm>. Acesso em 31 ago. 2004.

(1991). Substitutivo do Projeto de Lei no 203, de 1991. Institui a Política Nacional de Resíduos Sólidos, seus princípios, objetivos e instrumentos, e estabelece diretrizes e normas de ordem pública e interesse social para o gerenciamento dos diferentes tipos de resíduos sólidos. Disponível em: <http://www.al.sp.gov.br/residuos/pl203.pdf>. Acesso em 08 ago. 2004.

(2004). Presidência da República - índice de leis federais. Disponível em: <http://www.planalto.gov.br/legisla.htm>. Acesso em 25 ago. 2004.

CÂMARA DE COMÉRCIO E INDÚSTRIA BRASIL-ALEMANHA (2004). Selos de qualidade mais conhecidos na Europa. Disponível em: <http://www.ahk.org.br/selos-qualidade.asp>. Acesso em 10 ago. 2004.

CAMPANILI, M. (2002). Kapaz entrega projeto para Política de Resíduos. O Estado de São Paulo, São Paulo, 22 mai. Disponível em: <http://www.estadao.com.br/ciencia/ noticias/2002/mai/22/252.htm>. Acesso em 08 set. 2004.

CETEA - CENTRO DE TECNOLOGIA DE EMBALAGEM (CETEA) (2004). Área de Embalagem e Meio Ambiente - pesquisas desenvolvidas pelo Centro. Disponível em: <http://www.cetea.ital.org.br/emb_meio_ambiente.htm>. Acesso em 27 jun. 2004.

CNTL - CENTRO NACIONAL DE TECNOLOGIAS LIMPAS (2003). Disponível em: $<$ http://www.rs.senai.br/cntl/>. Acesso em 23 set. 2003.

CHEHEBE, J. R. B. (1997). Análise do ciclo de vida de produtos: ferramenta gerencial da ISO 14000. Rio de Janeiro: Qualitymark. 120 p.

CETESB - COMPANHIA DE TECNOLOGIA DE SANEAMENTO AMBIENTAL (2003). Informações sobre conceitos relativos à prevenção à poluição. Disponível em: <http://www.cetesb.sp.gov.br/Ambiente/prevencao_poluicao/conceitos.asp>. Acesso em 23 set. 2003.

CEMPRE - COMPROMISSO EMPRESARIAL PARA RECICLAGEM (2004a). Papel ondulado: o mercado para reciclagem (ficha técnica). Disponível em: $<$ http://www.cempre.org.br/fichas_tecnicas_papel_ondulado.php>. Acesso em 23 set. 2004. 
(2004b). Plástico rígido: o mercado para reciclagem (ficha técnica). Disponível

em: <http://www.cempre.org.br/fichas_tecnicas_plastico_rigido.php>. Acesso em 23 set. 2004.

(2004c). Vidro: o mercado para reciclagem (ficha técnica). Disponível em: <http://www.cempre.org.br/fichas_tecnicas_vidro.php>. Acesso em 23 set. 2004.

CONAMA - CONSELHO NACIONAL DO MEIO AMBIENTE (2003). Resolução

313, de 29 de outubro de 2002. Dispõe sobre o Inventário Nacional de Resíduos Sólidos Industriais.

Disponível em: <http://www.mma.gov.br/port/conama/res/res02/res31302.html>. Acesso em 28 mar. 2003.

DORN, E. W.; McADAMS, M. T. (1982). Waste exchanges: an informal tool for linking waste generators with users. In: HUISINGH, D.; BAILEY, V. (ed.) Making pollution prevention pay: ecology with economy as policy. New York: Pergamon Press. p. 86-94.

ECOCYCLE (2003). Newsletter com informações sobre políticas e assuntos técnicos relativos ao gerenciamento do ciclo de vida de produtos. Disponível em: <http://www.ec.gc.ca/ecocycle/issue1/en/index.cfm>. Acesso em 20 jun. 2004

EUROPA (2004). Informações sobre paises-membros e candidatos. Disponível em: $<$ http://europa.eu.int/comm/enlargement/links/governments.htm>. Acesso em 29 set. 2004.

FONSECA, Y. M. F. et al. (2005). Bolsa de resíduos em Minas Gerais e em outros estados do Brasil. Disponível em: <http://www.resol.com.br/textos/BOLSA\%20DE \%20RESÍDUOS\%20EM\%20MINAS\%20GERAIS.htm>. Acesso em 08 nov 2005.

FRITSCH, V. E. (2000). Os resíduos sólidos e seus aspectos legais, doutrinários e jurisprudenciais. Porto Alegre: UE/Secretaria Municipal de Cultura. 143 p.

FUNDAÇÃO CARLOS ALBERTO VANZOLINI (2000). Produção e tecnologias limpas; Conectivo (Boletim Fundação Paulo Vanzolini), ano IX, ${ }^{\circ} 42$, mar-abr. Disponível em <http://www.vanzolini.org.br/publica/boletim42/producaolimpa.pdf> Acesso em 14 ago. 2003.

GASI, T.M.T. (2002). “A mesa redonda paulista de Produção Mais Limpa”. In: III Workshop de Adequação Ambiental em Manufatura. Escola de Engenharia de São Carlos.

HOPE, E. (2004). A integração da embalagem no sistema logístico. Disponível em: <http://www.guiadelogistica.com.br/ARTIGO53.htm>. Acesso em 19 ago. 2004. 
ISO - INTERNATIONAL ORGANIZATION FOR STANDARDIZATION (2004).

Site da organização, com informações sobre normas, comitês elaboradores, etc. Disponível em <www.iso.org>. Acesso em 15 jun. 2004.

JACKSON, T. (ed.) (1993). Clean production strategies - Developing preventive environmental management in the industrial economy. Boca Raton: Lewis Publishers. 415 p.

LA ROVERE, E.L. (coord.) et al. (2003). Manual de auditoria ambiental. $2^{\mathrm{a}}$ ed. Rio de Janeiro: Qualitymark. 152 p.

MANZINI, E.; VEZZOLI C. (2002). O desenvolvimento de produtos sustentáveis. São Paulo: Editora da Universidade de São Paulo. 368 p.

MUSEU DE ARTE MODERNA DO RIO DE JANEIRO - INSTITUTO DE DESENHO INDUSTRIAL (1976). Manual de planejamento de embalagens. Rio de Janeiro: Mic. 98 p.

MOURA, R. A. (1983). Sistemas e técnicas de movimentação e armazenagem de materiais: materials handling. $3^{\text {a }}$. ed. São Paulo: Imam. 655 p.

MOURA, R. A.; BANZATO, J. M. (1997). Embalagem, unitização \& conteinerização. 2a. ed. São Paulo : IMAM. 354 p.

MOURA, R. A. (1983). Sistemas e técnicas de movimentação e armazenagem de materiais: materials handling. $3^{\mathrm{a}}$. ed. São Paulo: Imam. 655 p.

OLIVEIRA, J.F.G. (2002). "AMA - Adequação Ambiental em Manufatura” in: III Workshop de Adequação Ambiental em Manufatura. Escola de Engenharia de São Carlos.

PINATTI, A. E. (1999). $O$ design de embalagem de consumo e o meio ambiente - $O$ sistema ecológico-ambiental: ecodesign. São Paulo. Tese (Doutorado) - Faculdade de Arquitetura e Urbanismo (FAU), Universidade de São Paulo. 428 p.

RHYNER, C. R. et al (1995). Waste management and resource recovery. Boca Raton: Crc, 1995.524 p.

ROYSTON, M. G. (1982). Making pollution prevention pay. In: HUISINGH, D.; BAILEY, V. (ed.), op. cit. p.1-16.

SCHILlinG, G. E. M. et al. (2000). Auditorias de Redução de Resíduos. In: CONGRESSO BRASILEIRO DE ENGENHARIA SANITÁRIA E AMBIENTAL, 20², 1996, Rio de Janeiro. FIESP/CIESP - Bolsa de resíduos - banco de textos. Disponível em: <http://www2.ciesp.org.br/bolsa/outros_servicos/banco_textos/ detalhes_texto.asp?ID=16>. Acesso em 19 set. 2003. 
SELKE, S. E. M. (1994). Packaging and the environment: alternatives, trends, and solutions. Lancaster, Pa.: Technomic Pub. Co. 248 p.

SESANA, C. (2005). Re: [Conama] -> Link fale conosco - Site CONAMA [mensagem pessoal]. Mensagem recebida por<tish@terra.com.br> em 22 abr.

SHEN, T. T. (1995). Industrial pollution prevention. Berlin: Springer. 374 p.

SOUSA, C. S. M. (2000). Impacto ambiental: parâmetro para projeto de embalagens o caso do plástico. São Paulo. Tese (Doutorado) - Faculdade de Arquitetura e Urbanismo (FAU) Universidade de São Paulo. 234 p.

SUSAG, R. H. (1982). Pollution prevention pays: the 3M corporate experience. In: HUISINGH, D.; BAILEY, V. (ed.), op. cit. p. 17-22.

THOMAS, S. T. (1995). Facility manager's guide to pollution prevention and waste minimization. Washington, D. C.: BNA Books. 271 p.

UNIÃO EUROPÉIA (1957). Tratado de Roma, de 25 de março de 1957. Institui a Comunidade Européia. Disponível em: $<$ http://europa.eu.int/abc/obj/treaties/pt/pttoc05.htm>. Acesso em 23 ago. 2004. (1992). Tratado de Maastricht, de 7 de Fevereiro de 1992. Institui a União Européia. Disponível em: <http://europa.eu.int/abc/obj/treaties/pt/pttoc01.htm>. Acesso em 23 ago. 2004.

(1994). Diretiva 94/62/CE, de 20 de Dezembro de 1994, Dispõe sobre as embalagens e os resíduos de embalagens. Disponível em: $<$ http://europa.eu.int/smartapi/cgi/sga_doc?smartapi!celexplus!prod!DocNumber\&l g=pt\&type_doc=Directive\&an_doc=1994\&nu_doc=62>. Acesso em 10 ago. 2004.

VALLE, C. E. (2002). Qualidade ambiental: ISO 14000. 4ª . ed. rev. e ampl. São Paulo: Ed. SENAC São Paulo. 199 p.

VENDA DE CARROS no Brasil cresce 11\% em 2004 (2005). Disponível em: $<$ http://carros.uol.com.br/icarros/noticias/noticia.jsp?id=1130>. Acesso em 16 set. 2005. 


\section{Outras referências consultadas}

JORNAL DE PLÁSTICOS (2005). Notícias da $3^{\mathrm{a}}$ Brasilpack. Disponível em: $<$ http://www.jorplast.com.br/jpmai02/pag12.html>. Acesso em 02 mai.

UNIPAC (2000). Palete tampa - folheto informativo (agosto).

_ (2001). Caixamóbil - folheto informativo (julho). (2002). Embalagens KLT - folheto informativo (julho).

VCI Brasil Indústria e Comércio de Embalagens Ltda. (2005). O que é VCI. Disponível em: <http://www.vcibrasil.com.br/vci.php>. Acesso em 02 mai. 


\section{APÊNDICE I - Questionário}

\section{1) A empresa (dados gerais)}

Razão social / nome:

Endereço / localização da planta:

Contato na empresa / responsável(is) pelas informações:

Data da instalação:

Número de funcionários:

\begin{tabular}{|l|l|}
\hline Administração & \multicolumn{1}{|l|}{} \\
\hline Produção & \\
\hline Qualidade & \\
\hline Outras áreas (especificar): & \\
\hline & \\
\hline & \\
\hline & \\
\hline & \\
\hline Total & \\
\hline
\end{tabular}

Produtos fabricados na planta:

\begin{tabular}{|l|l|l|l|l|}
\hline Produto & $\begin{array}{c}\text { Linha de } \\
\text { produção }\end{array}$ & Utilização & $\begin{array}{c}\text { Produção diária } \\
\text { (média) }\end{array}$ & Destino (*) \\
\hline & & & & \\
\hline & & & & \\
\hline & & & & \\
\hline & & & & \\
\hline & & & & \\
\hline & & & & \\
\hline & & & & \\
\hline & & & & \\
\hline & & & & \\
\hline
\end{tabular}

(*) I: mercado interno; E: exportação sem modificações; EM: exportação com modificação

Processos básicos de fabricação (montagem, usinagem, conformação, pintura, etc.):

Instalações $\left(\mathrm{em} \mathrm{m}^{2}\right)$ :

\begin{tabular}{|l|l|}
\hline Área total da planta & \\
\hline Área construída da planta & \\
\hline Setores: & \\
\hline - Montagem & \\
\hline - Pintura & \\
\hline - Fabricação de componentes (se houver) & \\
\hline - Armazenagem de produtos acabados & \\
\hline - Armazenagem de componentes & \\
\hline Outros setores (especificar): & \\
\hline \multicolumn{2}{|l|}{} \\
\hline & \\
\hline
\end{tabular}




\section{2) O produto:}

Produção média: unidades/dia

Utilização:

Destinação: mercado interno: $\%$; mercado externo: $\%$

Frequiência de entrega do produto pronto:

$\square$ Diária $\square$ Semanal $\square$ Quinzenal $\square$ Mensal $\square$ Irregular

$\square$ Outro intervalo (especificar): Lotes: unidades / (dia, semana)

Componentes do produto:

Total (componentes com que o produto já sai da planta)

Componentes fabricados na planta

Componentes recebidos pela planta

Componentes recebidos:

\begin{tabular}{|c|c|c|c|c|}
\hline Componente & $\begin{array}{l}\text { Fornecedor / } \\
\text { cidade de origem }\end{array}$ & $\begin{array}{l}\text { Frequiência de } \\
\text { entrega }(*)\end{array}$ & $\begin{array}{l}\text { Unidades } \\
\text { utilizadas por } \\
\text { produto }\end{array}$ & Embalagem \\
\hline & & & & \\
\hline & & & & \\
\hline & & & & \\
\hline & & & & \\
\hline & & & & \\
\hline & & & & \\
\hline & & & & \\
\hline & & & & \\
\hline & & & & \\
\hline & & & & \\
\hline & & & & \\
\hline & & & & \\
\hline & & & & \\
\hline & & & & \\
\hline & & & & \\
\hline & & & & \\
\hline & & & & \\
\hline & & & & \\
\hline & & & & \\
\hline & & & & \\
\hline & & & & \\
\hline & & & & \\
\hline
\end{tabular}

(*) D: Diária; S: semanal; Q: Quinzenal; M: mensal; I: irregular; outro intervalo: especificar 
3a) O componente:

\begin{tabular}{|l|l|}
\hline Peso unitário $(\mathrm{Kg})$ & \\
\hline Dimensões $(\mathrm{C} \times \mathrm{L} \times \mathrm{H}, \mathrm{D} \times \mathrm{H})(\mathrm{mm})$ & \\
\hline Material(is) & \\
\hline Lote recebido por vez & \\
\hline Quantidade utilizada por motor & \\
\hline Procedência (fabricante, cidade) & \\
\hline
\end{tabular}

\section{3b) Relação com fornecedores de componentes}

Exigências no esquema de suprimentos em relação ao fornecedor:

Certificações de qualidade, sistemas de auditoria

Desenvolvimento conjunto de novos produtos, processos e/ou atividades de P\&D

Padrões internacionais de qualidade, quantidade e preço

Localização a poucos quilômetros (do cliente ou fornecedor)

Flexibilidade de volume, prazos e mix de entregas

Serviço de pós-venda - assistência técnica

Interligação via meio eletrônico

Parceria tecnológica com empresas e/ou instituições de tecnologia

Capacidade financeira para investimentos

Formação técnica e educacional de mão-de-obra

Disponibilização de engenheiro ou técnico residente

Proximidade do cliente ou fornecedor de centro técnico ou engenharia

Outras (especificar):

Práticas no esquema de suprimentos em relação ao fornecedor:

Contratos restritos à compra e venda de produtos/insumos

Contratos de longo prazo (superiores a um ano)

Exclusividade na comercialização

Contratos de assistência técnica/prestação de serviços pós-venda

Comunicação via meio eletrônico

Troca sistemática de informações sobre qualidade e desempenho dos produtos

Troca sistemática de informações visando identificar mudanças no perfil do mercado consumidor

Desenvolvimento conjunto de produtos/processos e/ou atividades de P\&D

Parceria entre as empresas para qualificação e desenvolvimento de pessoas

Outras (especificar):

- Observações: 
4a) A embalagem:

\begin{tabular}{|l|l|}
\hline Peso (embalagem + conteúdo) $(\mathrm{Kg})$ & \\
\hline Peso (embalagem vazia) $(\mathrm{Kg})$ & \\
\hline Dimensões $(\mathrm{C} \times \mathrm{L} \times \mathrm{H}, \mathrm{D} \times \mathrm{H})(\mathrm{mm})$ & \\
\hline Material(is) & \\
\hline Capacidade (unidades do componente) & \\
\hline
\end{tabular}

\section{4b) Acessórios da embalagem}

\begin{tabular}{|l|c|c|}
\hline & Tipo & Quantidade \\
\hline Fechamento (pregos, grampos) & & \\
\hline Informação (adesivos, etiquetas) & & \\
\hline Fixação / proteção do conteúdo & & \\
\hline
\end{tabular}

Fluxo da embalagem na planta (sequiência do processo / diagrama de blocos):

legenda:

G: geração de resíduos de embalagens

E: equipamentos/formas de processamento
A; armazenamento / estocagem de embalagens D: Áreas de disposição 
Armazenagem na planta antes da utilização do componente:

\begin{tabular}{|l|l|}
\hline Tempo de armazenagem (dias) & \\
\hline Forma de estocagem (pilhas, suspensa, outra) & \\
\hline Quantidade máxima de empilhamento (unidades) & \\
\hline
\end{tabular}

Armazenagem na planta depois da utilização do componente:

Tempo de armazenagem até o retorno ao fornecedor (dias)

Forma de estocagem (pilhas, suspensa, outra)

Quantidade máxima de empilhamento (unidades)

Processo de preparação para reutilização

- Total de empregados que trabalham no processo:

- Atividades realizadas (transporte, separação, empilhamento, outras):

\section{4) Gerenciamento atual}

\section{a) utilização de embalagens}

- Já foi feito um levantamento de tipos e quantidades de embalagens envolvidas no(s) processo(s)? Quando? Há registros desse levantamento?

- Principais locais / setores utilizadores de embalagens:

- Há algum plano ou conjunto de medidas para o gerenciamento de resíduos? $\square \mathrm{S} \square \mathrm{N}$

- Considera embalagens? Se sim, como? O que fala sobre eles? (objetivo, metas, resultados, processos de avaliação, monitoramento, documentação)

\section{b) geração de $\mathbf{R E}$}

- A empresa possui um inventário de fornecedores de embalagens (indicação da origem, quantidades envolvidas, grupos ou lotes)? $\square \mathrm{N} \square \mathrm{S}$

- Já foi feito um levantamento de tipos e quantidades de embalagens geradas no(s) processo(s)? Quando? Há registros desse levantamento?

- Principais locais / setores geradores de RE's: 
- Almoxarifados, áreas de estocagem de materiais: layout, instalações, tempo médio de permanência (tempo entre estocagem a utilização):

- Há requisitos para manutenção e disposição dos resíduos de embalagens? $\square \mathrm{N} \square \mathrm{S}$

\section{b) coleta de $\mathbf{R E}$}

- Há funcionários trabalhando especificamente na coleta de RE's? $\square \mathrm{N} \square \mathrm{S}$

- Há algum programa interno de coleta seletiva? Em quais setores? Descrever os resíduos coletados (tipo de embalagem, material, quantidades):

- Na empresa, é feita:

Seleção: $\square \mathrm{S} \square \mathrm{N}$

Manuseio: $\square \mathrm{S} \square \mathrm{N}$

Triagem: $\square \mathrm{S} \square \mathrm{N}$

- A região da empresa é atendida pelo programa municipal de coleta seletiva? Qual o dia?

- Há setores que dispõem seus RE's diretamente para serem recolhidos pela coleta seletiva? Quais? Quais os tipos de resíduos de embalagens destinados diretamente para a coleta seletiva? Quais os materiais? (estimar as quantidades de cada material e total, em $\mathrm{kg}$ por dia/semana/mês):

- EPI utilizado para lidar com os RE's gerados, se e quando necessário:

\section{c) armazenamento de $\mathbf{R E}$}

- Há um local específico para armazenamento de resíduos de embalagens? $\square \mathrm{N} \square \mathrm{S}$

- Local de armazenamento: localização (dentro ou fora da indústria), layout, instalações, tempo médio de permanência (tempo entre armazenamento e saída), sinalização: 
- Fontes dos resíduos ali armazenados (setores que contribuem):

- É mantido um registro ou algum tipo de controle das entradas e saídas?

d) forma de tratamento

- É empregada alguma forma de tratamento dos resíduos de embalagens? Para quais materiais? Onde é realizada (dentro ou fora da empresa)? Descrever brevemente o processo.

e) método de disposição

- Qual é(são) o(s) método(s) de disposição atualmente empregado(s)? Para quais tipos de material?

- Se a disposição é em aterro, o aterro de destino está localizado na própria cidade? $\square \mathrm{S} \square \mathrm{N}$ Onde?

- Quais as condições do aterro?

- A empresa visita / inspeciona o aterro? Com que freqüência?

\section{f) impactos}

- Informações sobre: descrição do uso; potenciais impactos ambientais no uso normal, incorreto, não-utilização e em caso de acidentes; modo de estocagem e disposição das embalagens. Onde estão? (na própria embalagem, em algum manual da empresa, etc.)

\section{g) 3R's:}

\section{Redução}

- Já há alguma forma de conscientização sobre as possibilidades ou a necessidade de reduzir o uso de embalagens? Em caso afirmativo, há um método definido? Para algum material em especial?

- Já foram identificadas oportunidades de redução de custos / prevenção à poluição / redução de resíduos (por exemplo, uso de materiais ambientalmente menos danosos ou que facilitem a reciclagem)? Citar exemplos de medidas que contribuíram para a redução no uso de embalagens. 


\section{Processo(s) de reciclagem}

- Os resíduos passam por algum processo de triagem e reciclagem? Em caso afirmativo, quais tipos de resíduo são reciclados? Dentro ou fora da empresa (setor específico, empresa terceirizada, centrais do município)? Descrever brevemente o processo.

- Qual o(s) tipo(s) de material(is) e produto(s) produzido(s) a partir desses resíduos?

- Qual a destinação desses novos materiais e produtos? A empresa utiliza algum(ns) desse(s) material(is) ou produto(s) ? Se sim, quais?

\section{Reutilização}

- Alguma porção desses resíduos é reutilizada? Onde? (na própria empresa?) Qual o(s) tipo(s) de material(is) reutilizado(s)? De que forma? Em que setor?

- Passam por algum tratamento especial? Qual?

\section{5) Outras questões}

- Possui departamento ambiental? $\square \mathrm{N} \square \mathrm{S}$

- Há algum grupo de estudo de questões ambientais? $\square \mathrm{N} \square \mathrm{S}$

- Como os aspectos ambientais da empresa (desempenho ambiental, programas e novas medidas) são informados aos funcionários?

- Quais são as formas de treinamento e conscientização dos funcionários sobre gerenciamento de resíduos (RE incluídos)?

- A empresa participa de algum tipo de bolsa de resíduos ou sistema de troca/venda e compra de resíduos? Qual? Com quais (tipos de) empresas? 
- Realiza algum tipo de avaliação ambiental? $\square \mathrm{N} \square \mathrm{S}$

- Em caso afirmativo, essas avaliações são realizadas por:

$\square$ funcionários da empresa $\square$ terceiros (outra empresa, consultores) $\square$ equipes mistas:

- Mudanças sendo estudadas (programas de melhoria de desempenho); previsão de implantação:

- Citar exemplos de programas e das melhorias obtidas - boas práticas (prevenção da poluição, produção mais limpa):

- As boas práticas da empresa são divulgadas aos fornecedores, clientes e sociedade em geral? $\square \mathrm{N} \square \mathrm{S}-\mathrm{Como}$ ?

Observações: 


\section{APÊNDICE II - Normas da Associação Brasileira de Normas Técnicas (ABNT)} relativas às embalagens (até janeiro de 2005)

\begin{tabular}{|c|c|c|c|}
\hline DESCRIÇÃO DA NORMA & $\begin{array}{c}\text { № } \\
\text { NBR }\end{array}$ & ANO & \begin{tabular}{|c|} 
№ \\
Páginas
\end{tabular} \\
\hline $\begin{array}{l}\text { ACONDICIONAMENTO E EMBALAGEM - CLASSIF. DE PRODUTROS ELÉTRICOS EM } \\
\text { FUNÇÃO DE SUAS SENSIBILIDADE E FRAGILIDADE }\end{array}$ & 13019 & 1993 & 2 \\
\hline AMOSTRA PARA ENSAIOS DE DESEMPENHO EM EMB. E ACONDICIONAMENTO & |12909 & 1993 & 1 \\
\hline AMPOLAS - CAPACIDADE VOLUMÉTRICA & 11281 & 1990 & 2 \\
\hline AMPOLAS - CONTROLE DA QUALIDADE & 11280 & 1990 & 10 \\
\hline AMPOLAS - RESISTÉNCIA DO ANEL A RUPTURA & 11284 & 1993 & 2 \\
\hline AMPOLAS - RESISTÉNCIA HIDROLÍTICA - ENSAIO EM VIDRO PULVERIZADO & 11285 & 1990 & 2 \\
\hline AMPOLAS - RESISTÉNCIA HIDROLÍTICA - ENSAIO POR FOTOMETRIA DE CHAMA & 11286 & 1990 & 10 \\
\hline AMPOLAS - VERIFICAÇÃO DE SIMETRIA & 11282 & 1993 & 2 \\
\hline AMPOLAS - VERIFICAÇÃO DE TENSÕES EXCESSIVAS & 11283 & 1990 & 1 \\
\hline $\begin{array}{l}\text { ARMAZENAMENTO, TRANSPORTE E MOVIMENTAÇÃO DOS ELEMENTOS COMPONENTES } \\
\text { DOS CARRETÉIS DE MADEIRA PARA CONDUTORES ELÉTRICOS }\end{array}$ & 7309 & 1982 & 4 \\
\hline ARTIGOS POLIMÉRICOS EM CONTATO COM ALIMENTOS - PROVA DE CESSÃO & 11287 & 1989 & 6 \\
\hline $\begin{array}{l}\text { ARTIGOS POLIMÉRICOS EM CONTATO COM ALIMENTOS - PROVA DE CESSÃO } \\
\text { MIGRAÇÃO DE ARSENICO }\end{array}$ & 11288 & 1989 & 2 \\
\hline $\begin{array}{l}\text { ARTIGOS POLIMÉRICOS EM CONTATO COM ALIMENTOS - PROVA DE CESSÃO } \\
\text { MIGRAÇÃO DE METAIS PESADOS - MÉTODO DO TUBO DE NESSLER }\end{array}$ & 11289 & 1989 & 2 \\
\hline $\begin{array}{l}\text { ARTIGOS POLIMÉRICOS EM CONTATO COM ALIMENTOS - PROVA DE CESSÃO } \\
\text { MIGRAÇÃO ESPECÍFICA DE DITIOCARBAMATOS, TIOURAMAS E XANTOGENATOS }\end{array}$ & 11289 & 1989 & 3 \\
\hline $\begin{array}{l}\text { ARTIGOS POLIMÉRICOS EM CONTATO COM ALIMENTOS - PROVA DE CESSÃO } \\
\text { MIGRAÇÃO DE FORMALDEIDO }\end{array}$ & 11291 & 1989 & 2 \\
\hline $\begin{array}{l}\text { ARTIGOS POLIMÉRICOS EM CONTATO COM ALIMENTOS - PROVA DE CESSÃO } \\
\text { MIGRAÇÃO ESPECÍFICA DE FENOIS E CRESOIS }\end{array}$ & 11292 & 1989 & 2 \\
\hline $\begin{array}{l}\text { ARTIGOS POLIMÉRICOS EM CONTATO COM ALIMENTOS - PROVA DE CESSÃO } \\
\text { MIGRAÇÃO ESPECÍFICA DE PEROXIDOS }\end{array}$ & 11293 & 1989 & 2 \\
\hline BALDES & 11275 & 1990 & 3 \\
\hline BARRICAS & 11277 & 1990 & 3 \\
\hline BOMBONAS & 11278 & 1990 & 3 \\
\hline CAIXA DE PAPELĀO ONDULADO & 5980 & 1974 & 30 \\
\hline $\begin{array}{l}\text { CARRETÉIS DE MADEIRA PARA ACONDICIONAMENTO DE FIOS E CABOS ELÉTRICOS } \\
\text { DIMENSÕES E ESTRUTURAS }\end{array}$ & 11137 & 2002 & 9 \\
\hline $\begin{array}{l}\text { CARRETÉIS DE MADEIRA PARA CORDOALHAS DE SETE FIOS DE AÇO ZINCADO - } \\
\text { CARACTERISTIICAS DIMENSIONAIS E ESTRUTURAIS }\end{array}$ & 7311 & 1982 & 4 \\
\hline $\begin{array}{l}\text { CARRETEL PARA ACONDICIONAMENTO DE FIOS E CABOS ELÉTRICOS - REQUISITOS DE } \\
\text { DESEMPENHO }\end{array}$ & 15126 & 2004 & 10 \\
\hline $\begin{array}{l}\text { COMPOSTOS DE PVC DESTINADOS A FABRICAÇÃO DE EMBALAGEM PARA PRODUTOS } \\
\text { ALIMENTÍCIOS }\end{array}$ & 11740 & 1977 & 7 \\
\hline CONDICIONAMENTO CLIMÁTICO DE EMBALAGEM E ACONDICIONAMENTO & 9477 & 1986 & 2 \\
\hline CONTENTOR FLEXIVEL - REQUISITOS E MÉTODOS DE ENSAIO & 15009 & 2003 & 12 \\
\hline CORTA-FLUXO " CONTA-GOTAS " & 13388 & 1995 & 8 \\
\hline CORTA-FLUXO " CONTA-GOTAS " & 13389 & 1995 & 4 \\
\hline EMBALAGEM & 11273 & 1990 & 2 \\
\hline EMBALAGEM - DESEMPENHO & 9460 & 1986 & 8 \\
\hline EMBALAGEM - DETERMINAÇÃO DA ESTANQUEIDADE & 9470 & 1986 & 2 \\
\hline EMBALAGEM - DETERMINAÇÃO DA RESISTÉNCIA A PRESSÃO INTERNA & 9471 & 1986 & 2 \\
\hline EMBALAGEM - DETERMINAÇÃO DA RESISTÊNCIA AO FOGO & 9472 & 1986 & 2 \\
\hline EMBALAGEM - DETERMINAÇÃO DO DESEMPENHO EM PERFURAÇÃO & 9464 & 1986 & 3 \\
\hline EMBALAGEM - DETERMINAÇÁO DO DESEMPENHO EM COMPRESSÁO LOCALIZADA & 9465 & 1986 & 3 \\
\hline EMBALAGEM - DETERMINAÇÃO DO DESEMPENHO EM BAIXA PRESSÃO & 9466 & 1986 & 3 \\
\hline EMBALAGEM - DETERMINAÇÃO DO DESEMPENHO EM EXPOSIÇÃO A UMIDADE & 9468 & 1986 & 3 \\
\hline EMBALAGEM - DETERMINAÇÃO DO DESEMPENHO COM CONTEÚDO AGRESSIVO & 9469 & 1986 & 2 \\
\hline EMBALAGEM - DETERMINAÇÃO DO DESEMPENHO EM LEVANTAMENTO & 9476 & 1986 & 3 \\
\hline EMBALAGEM DE LEITE PASTEURIZADO - FILME DE POLIETILENO DE BAIXA DENSIDADE & 10533 & 1988 & 7 \\
\hline EMBALAGEM DE PAPELÃO ONDULADO - DETERMINAÇÃO DAS DIMENSÕES INTERNAS & 6739 & 2003 & 5 \\
\hline $\begin{array}{l}\text { EMBALAGEM DE PAPELÁO ONDULADO - DETERMINAÇÁO DAS DIMENSÖES INTERNAS DA } \\
\text { CAIXA }\end{array}$ & 14979 & 2003 & 5 \\
\hline EMBALAGEM DE PRODUTOS PERIGOSOS - CLASSES 1,3,4,5,6, E 8 & 11564 & 2002 & 7 \\
\hline EMBALAGEM E ACONDICIONAMENTO & 9198 & 1985 & 9 \\
\hline
\end{tabular}




\begin{tabular}{|c|c|c|c|}
\hline DESCRIÇÃO DA NORMA & $\begin{array}{c}\text { № } \\
\text { NBR }\end{array}$ & ANO & \begin{tabular}{|c|} 
№ \\
Páginas \\
\end{tabular} \\
\hline $\begin{array}{l}\text { EMBALAGEM E ACONDICIONAMENTO - DETERMINAÇÃO DO DESEMPENHO EM VIBRAÇÃO } \\
\text { VERTICAL }\end{array}$ & 9461 & 1986 & 3 \\
\hline $\begin{array}{l}\text { EMBALAGEM E ACONDICIONAMENTO - DETERMINAÇĀO DO DESEMPENHO EM CHOQUE } \\
\text { HORIZONTAL }\end{array}$ & 9462 & 1986 & 5 \\
\hline $\begin{array}{lllllll}\text { EMBALAGEM E } & \text { ACONDICIONAMENTO } & \text { - } & \text { DETERMINAÇÃO } & \text { DO } & \text { DESEMPENHO } & \text { EM } \\
\text { OSCILAÇÃO HORIZONTAL } & & & & \end{array}$ & & 1986 & 3 \\
\hline $\begin{array}{lllllll}\text { EMBALAGEM E ACONDICIONAMENTO } & \text { - } & \text { DETERMINAÇÃO } & \text { DO } & \text { DESEMPENHO } & \text { EM } \\
\text { EXPOSIÇÃO A CHUVA } & & & & \end{array}$ & 9467 & 1986 & 3 \\
\hline EMBALAGEM E ACONDICIONAMENTO - DETERMINAÇÃO DO DESEMPENHO EM QUEDA & 9474 & 1986 & 7 \\
\hline 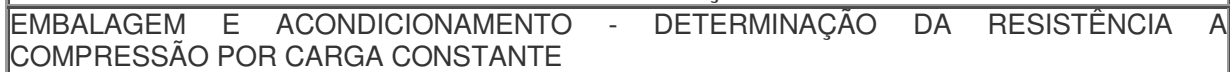 & 9475 & 1986 & 4 \\
\hline EMBALAGEM FLEXÍVEL & 11724 & 1979 & 5 \\
\hline 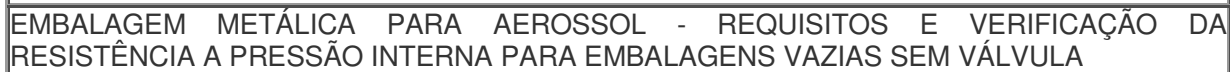 & 14720 & 2001 & 4 \\
\hline $\begin{array}{l}\text { EMBALAGEM PARA ARTIGO ODONTO-MÉDICO HOSPITALAR ESTERILIZADO POR OXIDO } \\
\text { DE ETILENO }\end{array}$ & 13386 & 1995 & 5 \\
\hline EMBALAGEM PARA ESTERILIZAÇÃO POR RADIAÇÃO IONIZANTE & 13387 & 1995 & 5 \\
\hline EMBALAGEM PARA ISOLAMENTO TÉRMICO - DETERMINAÇÃO DO DESEMPENHO & 9473 & 1986 & 3 \\
\hline EMBALAGEM PARA PRODUTOS ALIMENTÍCIOS - REQUISITOS E MÉTODOS DE ENSAIO & 14910 & 2002 & 24 \\
\hline $\begin{array}{l}\text { EMBALAGEM PLÁSTICA PARA AGUA MINERAL E DE MESA - GARRAFÃO RETORNÁVEL } \\
\text { REQUISITOS PARA LAVAGEM, ENCHIMENTO E FECHAMENTO }\end{array}$ & 14637 & 2001 & 5 \\
\hline $\begin{array}{l}\text { EMBALAGEM PLÁSTICA PARA AGUA MINERAL E DE MESA - GARRAFÃO RETORNÁVEL } \\
\text { REQUISITOS E METODOS DE ENSAIO }\end{array}$ & 14222 & 1998 & 6 \\
\hline $\begin{array}{l}\text { EMBALAGEM PLÁSTICA PARA AGUA MINERAL E DE MESA - TAMPA PARA GARRAFÃO } \\
\text { RETORNAVEL - REQUISITOS E METODOS DE ENSAIO }\end{array}$ & 14328 & 1999 & 4 \\
\hline $\begin{array}{l}\text { EMBALAGEM PLÁSTICA PARA AGUA MINERAL E DE MESA - GARRAFÃO RETORNAVEL } \\
\text { REQUISITOS PARA DISTRIBUIÇÃO }\end{array}$ & 14638 & 2001 & 5 \\
\hline EMBALAGEM RIGIDA VAZIA DE AGROTÓXICO - PROCEDIMENTOS DE LAVAGEM & 13968 & 1997 & 8 \\
\hline $\begin{array}{l}\text { EMBALAGEM RIGIDA VAZIA DE AGROTÓXICO - DESTINAÇÃO FINAL DA EMBALAGEM } \\
\text { LAVADA - PROCEDIMENTO }\end{array}$ & 14719 & 2001 & 15 \\
\hline $\begin{array}{l}\text { EMBALAGEM SECUNDÁRIA E ACONDICIONAMENTO UTILIZADO PARA FERRAGENS DE } \\
\text { LINHAS AÉREAS DE DISTRIBUIÇÃO - DIMENSÕES E ESTRUTURA }\end{array}$ & 10534 & 1988 & 65 \\
\hline $\begin{array}{l}\text { EMBALAGENS ADEQUADAS A UNIDADE DE CARGA DE 1140MM X 1140MM - DIMENSÕES } \\
\text { PLANAS }\end{array}$ & 8730 & 1985 & 5 \\
\hline EMBALAGENS COMPOSTAS & 11279 & 1990 & 6 \\
\hline $\begin{array}{l}\text { EMBALAGENS DE MADEIRA E DE PAPELÃO ONDULADO PARA ISOLADORES DE PINO } \\
\text { CARACTERISTICAS DIMENSIONAIS E ESTRUTURAIS }\end{array}$ & 9335 & 1986 & 8 \\
\hline $\begin{array}{l}\text { EMBALAGENS DE MADEIRA PARA ISOLADORES DE DISCO - CARACTERISTICAS } \\
\text { DIMENSIONAIS E ESTRUTURAIS }\end{array}$ & 9333 & 1986 & 6 \\
\hline $\begin{array}{l}\text { EMBALAGENS DE MADEIRA PARA ISOLADORES DE PEDESTAL - CARACTERISTICAS } \\
\text { DIMENSIONAIS E ESTRUTURAIS }\end{array}$ & 9336 & 1986 & 7 \\
\hline $\begin{array}{l}\text { EMBALAGEM DE PAPELÃO ONDULADO PARA ISOLADORES DE ROLDANA E CASTANHA } \\
\text { CARACTERISTICAS DIMENSIONAIS E ESTRUTURAIS }\end{array}$ & 9334 & 1986 & 6 \\
\hline EMBALAGENS FLEXIVEIS - ANÁLISE DE SOLVENTES RESIDUAIS & 13058 & 2003 & 7 \\
\hline 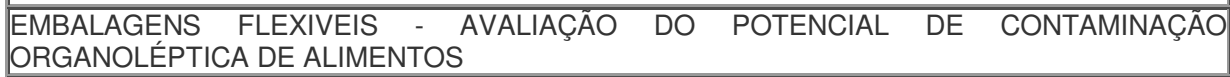 & 13177 & 1994 & 4 \\
\hline EMBALAGENS METÁLICAS - LATAS & 10531 & 1988 & 12 \\
\hline $\begin{array}{l}\text { EMBALAGENS METALICAS PARA AEROSSOL - CONTEÚDO DE PRODUTOS PRÉ-MEDIDOS - } \\
\text { REQUISITOS PARA ENVASAR E DECLARAR VOLUMES }\end{array}$ & 14721 & 2001 & 5 \\
\hline EMBALAGENS PLÁSTICAS (NOTA: ERRATA INCORPORADA) & 11136 & 1990 & 3 \\
\hline EMBALAGENS PLÁSTICAS PARA ÁGUA SANITÁRIA E ALVEJANTES A BASE DE CLORO & 13390 & 1995 & 3 \\
\hline EMBALAGENS PLÁSTICAS PARA ALCOOL - REQUISITOS E METODOS DE ENSAIO & 5991 & 1997 & 4 \\
\hline $\begin{array}{l}\text { EMBALAGEM VAZIA DE AGROTÓXICOS - DESTINAÇÃO FINAL DE EMBALAGENS NÃO } \\
\text { LAVADAS - PROCEDIMENTO }\end{array}$ & 14935 & 2003 & 11 \\
\hline EMPREGO DE ROLHAS METALICAS TIPO COROA PARA FECHAMENTO DE GARRAFAS & 11135 & 1990 & 4 \\
\hline FILMES PLASTICOS - VERIFICAÇÃO DA TRANSPARENCIA - METODO DE ENSAIO & 13056 & 2000 & 2 \\
\hline $\begin{array}{l}\text { FILMES PLASTICOS - VERIFICAÇÃO DA RESISTENCIA A PERFURAÇÃO ESTATICA } \\
\text { METODO DE ENSAIO }\end{array}$ & 14474 & 2000 & 2 \\
\hline $\begin{array}{l}\text { FRASCOS DE VIDRO PARA PRODUTOS FARMACÊUTICOS - REQUISITOS E MÉTODOS DE } \\
\text { ENSAIO }\end{array}$ & 11819 & 2004 & 36 \\
\hline $\begin{array}{l}\text { GARRAFAS } \\
\text { RETORNAVEIS DE USO } \\
\text { AGUARDENTES, SODAS E AGUAS GASEIFICADAS - FORMATOS, DIMENSÕES E CORES }\end{array}$ & 7842 & 1983 & 11 \\
\hline IDENTIFICAÇÃO DAS FACES DE EMBALAGEM PARA ENSAIO & 9478 & 1986 & 2 \\
\hline $\begin{array}{l}\text { IDENTIFICAÇÃO DAS PARTES DA EMBALAGEM DE PAPELAO ONDULADO ARMADA E } \\
\text { SELADA }\end{array}$ & 67 & 1979 & 2 \\
\hline LATAS & |11276 & 1990 & 6 \\
\hline
\end{tabular}




\begin{tabular}{|c|c|c|c|}
\hline DESCRIÇÃO DA NORMA & $\begin{array}{c}\text { № } \\
\text { NBR }\end{array}$ & ANO & $\begin{array}{c}\text { № } \\
\text { Páginas }\end{array}$ \\
\hline LATAS - DETERMINAÇÃO DA CAPACITAÇÃO TOTAL & 10532 & 1988 & 4 \\
\hline $\begin{array}{l}\text { MANUSEIO, MOVIMENTACCÃO, TRANSPORTE EXTERNO E ESTOCAGEM DE EMBALAGENS } \\
\text { DE PAPELAO ONDULADO PARA ISOLADORES }\end{array}$ & 9332 & 1986 & 3 \\
\hline $\begin{array}{l}\text { METODO PADRÃO DE TESTE PARA DENSIDADE DE PLASTICOS PELA TECNICA DE } \\
\text { GRADIENTE DE DENSIDADE }\end{array}$ & 11931 & 1977 & 3 \\
\hline $\begin{array}{l}\text { METODO PADRAO DE TESTE PARA DETERMINAÇAO DA PORCENTAGEM DE MONOMERO } \\
\text { NA POLIAMIDA - } 6\end{array}$ & 11928 & 1977 & 1 \\
\hline METODO PADRAO DE TESTE PARA PONTO DE FUSAO & 11932 & 1977 & 1 \\
\hline METODO PADRAO DE TESTE PARA PORCENTAGEM DE AGUA & 11929 & 1977 & 1 \\
\hline METODO PADRAO DE TESTE PARA VISCOSIDADE RELATIVA & 11930 & 1977 & 1 \\
\hline $\begin{array}{lllllll}\text { METODO PARA DETERMINAÇÃO } & \text { DE MONOMERO } \\
\text { CROMATOGRAFIA }\end{array}$ & 11934 & 1977 & 1 \\
\hline $\begin{array}{lllllll}\text { METODO PARA DETERMINAÇÃO } & \text { DE } & \text { MONOMERO } & \text { DE ESTIRENO } & \text { RESIDUAL POR } \\
\text { ESPECTROFOTOMETRIA } & & & & & \end{array}$ & 11933 & 1977 & 2 \\
\hline PALETES & 8334 & 1983 & 4 \\
\hline PALETES - DEFORMAÇÃO EM DIAGONAL & 8339 & 1983 & 3 \\
\hline PALETES - DETERMINAÇÃO DA RESISTÉNCIA A FLEXÃO DA FACE INFERIOR & 8336 & 1983 & 3 \\
\hline $\begin{array}{l}\text { PALETES - DETERMINAÇÃO DA RESISTENCIA A FLEXÃO DO PALETE APOIADO NA FACE } \\
\text { SUPERIOR }\end{array}$ & 8337 & 1983 & 3 \\
\hline $\begin{array}{l}\text { PALETES - DETERMINAÇÃO DA RESISTENCIA A FLEXÃO DO PALETE APOIADO NA FACE } \\
\text { INFERIOR }\end{array}$ & 8338 & 1983 & 3 \\
\hline PALETES - DETERMINAÇÃO DA RESISTENCIA A QUEDA LIVRE SOBRE QUINA & 8341 & 1983 & 2 \\
\hline PALETES - DIMENSÕES BÁSICAS & 8252 & 1983 & 1 \\
\hline PALETES - FLEXÃO DA FACE SUPERIOR & 8335 & 1983 & 2 \\
\hline PALETES DE MADEIRA - MATERIAIS & 9192 & 1985 & 6 \\
\hline PALETES DE MADEIRA - RESISTENCIA DA FIXAÇÃO AO ARRANCAMENTO & 8255 & 1983 & 2 \\
\hline PALETES DE MADEIRA SERRADA & 9193 & 1985 & 4 \\
\hline PAPELÃO ONDULADO E CAIXAS DE PAPELAO ONDULADO & 5985 & 1983 & 8 \\
\hline POLIAMIDA-6 PARA USO EM EMBALAGEM DE PRODUTOS ALIMENTICIOS & 11736 & 1977 & 2 \\
\hline 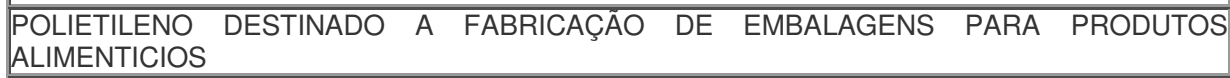 & 11737 & 1977 & 2 \\
\hline $\begin{array}{l}\text { POLIPROPILENO DESTINADO A FABRICAÇÃO } \\
\text { ALIMENTICIOS }\end{array}$ & 11738 & 1977 & 3 \\
\hline POLISTIRENO PARA USO EM EMBALAGENS DE PRODUTOS ALIMENTICIOS & 11739 & 1977 & 3 \\
\hline RECIPIENTES PLASTICOS PARA SOLUÇŌES PARENTERAIS DE GRANDES VOLUMES & 11818 & 1991 & 11 \\
\hline \begin{tabular}{|lccccc} 
ROLHAS METÁLICAS TIPO COROA & PARA & FECHAMENTO & DE & GARRAFAS \\
CARACTERISTICAS DIMENSIONAIS & & & & \\
\end{tabular} & 11134 & 1983 & 5 \\
\hline SACOS DE PAPEL PARA SUPERMERCADOS - DIMENSÕES & 13020 & 1993 & 4 \\
\hline SACOS DE PAPEL SIMPLES E MULTIFOLHADOS & 5986 & 1975 & 15 \\
\hline TAMBORES & 11274 & 1990 & 4 \\
\hline $\begin{array}{l}\text { TRANSPORTE, ARMAZENAMENTO E UTILIZAÇÃO DE } \\
\text { ELETRICOS EM MADEIRA }\end{array}$ & 7310 & 1982 & 4 \\
\hline UNIDADES DE CARGA - DIMENSÕES PLANAS & 8729 & 1985 & 4 \\
\hline
\end{tabular}

Fonte: ABRE (2005b) 
APÊNDICE III - Normas da série ISO 14000 em vigor (até maio de 2005)

\begin{tabular}{|c|c|c|c|c|}
\hline $\begin{array}{l}\text { Norma } \\
\text { ISO }\end{array}$ & Título & Publicação & NBR ISO & Situação \\
\hline \multicolumn{5}{|c|}{ Subcomitê SC-001 - Sistemas de Gestão Ambiental } \\
\hline 14001 & $\begin{array}{l}\text { Sistemas de gestão ambiental - } \\
\text { Especificação e diretrizes para uso }\end{array}$ & $09 / 96$ & 14001 & $\begin{array}{l}\text { Publicada } \\
\text { em 10/96 }\end{array}$ \\
\hline 14001 & Idem, revisão 1 (14000: 2004) & $11 / 04$ & 14001 & $\begin{array}{l}\text { Publicada } \\
\text { em } 12 / 04\end{array}$ \\
\hline 14004 & $\begin{array}{l}\text { Sistemas de gestão ambiental - Diretrizes } \\
\text { gerais sobre princípios, sistemas e técnicas } \\
\text { de apoio }\end{array}$ & 09/96 & 14004 & $\begin{array}{l}\text { Publicada } \\
\text { em } 10 / 96\end{array}$ \\
\hline 14004 & Idem, revisão 1 (14000: 2004) & $11 / 04$ & 14004 & $\begin{array}{l}\text { Em fase de } \\
\text { consulta } \\
\text { nacional em } \\
04 / 05\end{array}$ \\
\hline \multicolumn{5}{|c|}{ Subcomitê SC-002 - auditorias ambientais e investigações correlatas } \\
\hline 14015 & $\begin{array}{l}\text { Gestão ambiental - Avaliação ambiental de } \\
\text { locais e organizações (AVALOR) }\end{array}$ & $11 / 01$ & 14015 & $\begin{array}{l}\text { Publicada } \\
\text { em } 07 / 03\end{array}$ \\
\hline 19011 & $\begin{array}{l}\text { Diretrizes para auditorias de sistema de } \\
\text { gestão da qualidade e/ou ambiental } \\
\text { (substituiu as normas ISO 14010,14011 e } \\
\text { 14012) }\end{array}$ & $10 / 02$ & 19011 & $\begin{array}{l}\text { Publicada } \\
\text { em } 11 / 02\end{array}$ \\
\hline \multicolumn{5}{|c|}{ Subcomitê SC-003 - Rotulagem Ambiental } \\
\hline 14020 & $\begin{array}{l}\text { Rótulos e declarações ambientais - } \\
\text { Princípios gerais }\end{array}$ & $08 / 98$ & 14020 & $\begin{array}{l}\text { Publicada } \\
\text { em 06/02 }\end{array}$ \\
\hline 14021 & $\begin{array}{l}\text { Rótulos e declarações ambientais - } \\
\text { Autodeclarações ambientais (Rotulagem } \\
\text { ambiental - Tipo II) }\end{array}$ & $09 / 99$ & 14021 & $\begin{array}{l}\text { Publicada } \\
\text { em 04/04 }\end{array}$ \\
\hline 14024 & $\begin{array}{l}\text { Rótulos e declarações ambientais - } \\
\text { Rotulagem ambiental Tipo I - Princípios e } \\
\text { procedimentos }\end{array}$ & $04 / 99$ & 14024 & $\begin{array}{l}\text { Publicada } \\
\text { em } 04 / 04\end{array}$ \\
\hline 14025 & $\begin{array}{l}\text { Rótulos e declarações ambientais - } \\
\text { Declaração ambiental Tipo III - Princípios } \\
\text { e procedimentos }\end{array}$ & $\begin{array}{l}\text { em elaboração } \\
\text { (em 04/05) }\end{array}$ & 14025 & $-\ldots \ldots$ \\
\hline \multicolumn{5}{|c|}{ Subcomitê SC-004 - Avaliação de Desempenho Ambiental } \\
\hline 14031 & $\begin{array}{l}\text { Gestão ambiental - Avaliação de } \\
\text { desempenho ambiental - Diretrizes }\end{array}$ & $11 / 99$ & 14031 & $\begin{array}{l}\text { Publicada } \\
\text { em 02/04 }\end{array}$ \\
\hline $\begin{array}{l}\text { TR } \\
14032\end{array}$ & $\begin{array}{l}\text { Gestão ambiental - Exemplos de avaliação } \\
\text { de desempenho ambiental (ADA) }\end{array}$ & $11 / 99$ & 14032 & $\begin{array}{l}\text { Publicada } \\
\text { em 05/05 }\end{array}$ \\
\hline 14040 & $\begin{array}{l}\text { Gestão ambiental - Avaliação do ciclo de } \\
\text { vida - Princípios e estrutura }\end{array}$ & $06 / 97$ & 14040 & $\begin{array}{l}\text { Publicada } \\
\text { em } 11 / 01\end{array}$ \\
\hline $\begin{array}{l}14040- \\
\text { Rev.1 }\end{array}$ & $\begin{array}{l}\text { Gestão ambiental - Avaliação do ciclo de } \\
\text { vida - Princípios e estrutura }\end{array}$ & $\begin{array}{l}\text { em elaboração } \\
\text { (em 04/05) }\end{array}$ & 14040 - Ver. 1 & 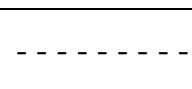 \\
\hline 14041 & $\begin{array}{l}\text { Gestão ambiental - Avaliação do ciclo de } \\
\text { vida - Definição de objetivo e escopo e } \\
\text { análise do inventário }\end{array}$ & $10 / 98$ & 14041 & $\begin{array}{l}\text { Publicada } \\
\text { em 05/04 }\end{array}$ \\
\hline 14042 & $\begin{array}{l}\text { Gestão ambiental - Avaliação do ciclo de } \\
\text { vida - Avaliação do impacto do ciclo de } \\
\text { vida }\end{array}$ & $03 / 00$ & 14042 & $\begin{array}{l}\text { Publicada } \\
\text { em 05/04 }\end{array}$ \\
\hline 14043 & $\begin{array}{l}\text { Gestão ambiental - Avaliação do ciclo de } \\
\text { vida - Interpretação do ciclo de vida }\end{array}$ & $03 / 00$ & 14043 & $\begin{array}{l}\text { Aguardando } \\
\text { publicação } \\
\text { (em 04/05) }\end{array}$ \\
\hline
\end{tabular}




\begin{tabular}{|c|c|c|c|c|}
\hline $\begin{array}{l}\text { Norma } \\
\text { ISO }\end{array}$ & Título & Publicação & NBR ISO & Situação \\
\hline \multicolumn{5}{|c|}{ Subcomitê SC-004 - Avaliação de Desempenho Ambiental (cont.) } \\
\hline 14044 & $\begin{array}{l}\text { Gestão ambiental - Avaliação do ciclo de } \\
\text { vida - Requisitos e orientações }\end{array}$ & $\begin{array}{l}\text { Em elaboração } \\
\text { (em 04/05) }\end{array}$ & 14044 & \\
\hline $\begin{array}{l}\text { TR } \\
14047\end{array}$ & $\begin{array}{l}\text { Gestão ambiental - Avaliação do ciclo de } \\
\text { vida - Exemplos ilustrativos de como } \\
\text { aplicar a ISO } 14042\end{array}$ & $10 / 03$ & TR 14047 & \\
\hline TS 14048 & $\begin{array}{l}\text { Gestão ambiental - Avaliação do ciclo de } \\
\text { vida - Formato da apresentação de dados }\end{array}$ & $04 / 02$ & 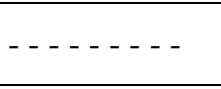 & \\
\hline 14048 & $\begin{array}{l}\text { Gestão ambiental - Avaliação do ciclo de } \\
\text { vida - Formato da apresentação de dados }\end{array}$ & $\begin{array}{l}\text { Em elaboração } \\
\text { (em 04/05) }\end{array}$ & 14048 & 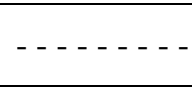 \\
\hline $\begin{array}{l}\text { TR } \\
14049\end{array}$ & $\begin{array}{l}\text { Gestão ambiental - Avaliação do ciclo de } \\
\text { vida - Exemplos de aplicação da ISO } 14041 \\
\text { para definição de objetivos e escopo e } \\
\text { análise de inventário }\end{array}$ & $03 / 00$ & TR 14049 & $\begin{array}{l}\text { Em } \\
\text { elaboração } \\
\text { (em 01/05) }\end{array}$ \\
\hline \multicolumn{5}{|c|}{$\begin{array}{l}\text { Subcomitê SC-006 - Termos e Definições } \\
\end{array}$} \\
\hline 14050 & Gestão ambiental - Vocabulário & $05 / 98$ & 14050 & $\ldots \ldots-\ldots$ \\
\hline $\begin{array}{l}14050 \\
\text { Rev.1 }\end{array}$ & Gestão ambiental - Vocabulário & $05 / 02$ & 14050 - Rev. 1 & $\begin{array}{l}\text { Publicada } \\
\text { em } 05 / 04\end{array}$ \\
\hline $\begin{array}{l}14050 \\
\text { Rev.2 }\end{array}$ & Gestão ambiental - Vocabulário & $\begin{array}{l}\text { Em elaboração } \\
\text { (em 04/05) }\end{array}$ & & \\
\hline \multicolumn{5}{|c|}{ Subcomitê SC-007 - Projetos para o Ambiente } \\
\hline $\begin{array}{l}\text { TR } \\
14062\end{array}$ & $\begin{array}{l}\text { Gestão ambiental - Integração de aspectos } \\
\text { ambientais no projeto e desenvolvimento de } \\
\text { produto }\end{array}$ & $11 / 02$ & $\begin{array}{l}\text { TR } \\
14062\end{array}$ & $\begin{array}{l}\text { Publicada } \\
\text { em 05/04 }\end{array}$ \\
\hline \multicolumn{5}{|c|}{ Subcomitê SC-008 - Comunicação Ambiental } \\
\hline 14063 & $\begin{array}{l}\text { Gestão ambiental - Comunicação ambiental } \\
\text { - Diretrizes e exemplos }\end{array}$ & $09 / 04$ & 14063 & - . . . . \\
\hline \multicolumn{5}{|c|}{ Subcomitê SC-009 - Mudanças Climáticas } \\
\hline $\begin{array}{l}14064 \\
\text { parte } 1\end{array}$ & $\begin{array}{l}\text { Gases de efeito estufa - Parte } 1: \\
\text { Especificação para a quantificação, } \\
\text { monitoramento e relato de emissões e } \\
\text { remoções de entidades }\end{array}$ & $09 / 04$ & 14064 parte 1 & 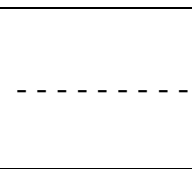 \\
\hline $\begin{array}{l}14064 \\
\text { parte } 2\end{array}$ & $\begin{array}{l}\text { Gases de efeito estufa - Parte } 2: \\
\text { Especificação para a quantificação, } \\
\text { monitoramento e relato de projetos } \\
\text { de emissões e remoções }\end{array}$ & $09 / 04$ & 14064 parte 2 & \\
\hline $\begin{array}{l}14064 \\
\text { parte } 3\end{array}$ & $\begin{array}{l}\text { Gases de efeito estufa - Parte 3: } \\
\text { Especificação e diretrizes para validação, } \\
\text { verificação e certificação }\end{array}$ & $09 / 04$ & 14064 parte 3 & \\
\hline 14065 & $\begin{array}{l}\text { Gases de efeito estufa - Especificação para } \\
\text { organismos que provêm verificação e } \\
\text { validação }\end{array}$ & $\begin{array}{l}\text { Em elaboração } \\
\text { (em 11/04) }\end{array}$ & 14065 & \\
\hline
\end{tabular}

